\title{
The Epidemiology and Demographics of Hip Dysplasia
}

\author{
Randall T. Loder ${ }^{1,2}$ and Elaine N. Skopelja ${ }^{3}$ \\ ${ }^{1}$ Section of Orthopedic Surgery, Riley Hospital for Children, ROC 4250, 705 Riley Hospital Drive, Indianapolis, IN 46202, USA \\ ${ }^{2}$ Department of Orthopaedic Surgery, Indiana University, Indianapolis, IN 46202, USA \\ ${ }^{3}$ Ruth Lilly Medical Library, Indiana University School of Medicine, Indianapolis, IN 46202, USA \\ Correspondence should be addressed to Randall T. Loder, rloder@iupui.edu
}

Received 15 May 2011; Accepted 17 June 2011

Academic Editors: S. Aldrian and T. Matsumoto

Copyright ( $\odot 2011$ R. T. Loder and E. N. Skopelja. This is an open access article distributed under the Creative Commons Attribution License, which permits unrestricted use, distribution, and reproduction in any medium, provided the original work is properly cited.

\begin{abstract}
The etiology of developmental dysplasia of the hip (DDH) is unknown. There are many insights, however, from epidemiologic/demographic information. A systematic medical literature review regarding DDH was performed. There is a predominance of left-sided (64.0\%) and unilateral disease (63.4\%). The incidence per 1000 live births ranges from 0.06 in Africans in Africa to 76.1 in Native Americans. There is significant variability in incidence within each racial group by geographic location. The incidence of clinical neonatal hip instability at birth ranges from 0.4 in Africans to 61.7 in Polish Caucasians. Predictors of DDH are breech presentation, positive family history, and gender (female). Children born premature, with low birth weights, or to multifetal pregnancies are somewhat protected from DDH. Certain HLA A, B, and D types demonstrate an increase in DDH. Chromosome 17q21 is strongly associated with DDH. Ligamentous laxity and abnormalities in collagen metabolism, estrogen metabolism, and pregnancy-associated pelvic instability are well-described associations with DDH. Many studies demonstrate an increase of $\mathrm{DDH}$ in the winter, both in the northern and southern hemispheres. Swaddling is strongly associated with DDH. Amniocentesis, premature labor, and massive radiation exposure may increase the risk of DDH. Associated conditions are congenital muscular torticollis and congenital foot deformities. The opposite hip is frequently abnormal when using rigorous radiographic assessments. The role of acetabular dysplasia and adult hip osteoarthritis is complex. Archeological studies demonstrate that the epidemiology of DDH may be changing.
\end{abstract}

\section{Introduction}

Demography is the study of human populations with reference to size, diversity, growth, age, and other characterizing statistics [1]. Epidemiology is the study of the incidence, distribution, and determinants of disease frequency in groups of individuals who happen to have characteristics in common (e.g., gender, ethnicity, exposure, genetics) [2, 3]. Incidence is the proportion of new cases in the population at risk during a specified time interval; prevalence is defined as the proportion of individuals with the disease in the study population of interest. Demographic and epidemiologic studies can determine risk factors for a disease/condition of interest, shed light on its etiology, and guide potential prevention programs.

Developmental dysplasia of the hip (DDH) is an epidemiologic conundrum [4]. DDH encompasses a wide spectrum of pathology ranging from a complete fixed dislocation at birth to asymptomatic acetabular dysplasia in the adult [59]. The epidemiologic literature regarding DDH is vast and confusing due to different definitions of hip dysplasia, different methods of diagnosis (e.g., physical exam, plain radiographs, ultrasound), different ages of the population studied (e.g., new born, 1 month old, 3 months old, etc.), clinical experience of the examiner [10], different ethnicities/races in the examined population, and different geographic locations within similar ethnic populations [11, 12]. Neonatal hip instability, now even more apparent with hip ultrasonography, must also be addressed [13, 14]; the clinical challenge is to separate the neonatal hip instability which resolves spontaneously from that which is significant [15-21].

The last major review of the epidemiology of hip diseases was in 1977 [22]. The goal of these manuscripts is to update the current knowledge of the epidemiology and demographics of pediatric hip disease which may lead to significant morbidity in later life. 


\section{Materials and Methods}

A systematic review was performed for articles on DDH in infants focusing on etiology, epidemiology, and diagnosis. Exclusion criteria were those manuscripts discussing surgery, therapy, rehabilitation and any foreign language articles without an English abstract. There were certain difficulties in searching the literature on this topic because of the many variant names for DDH. The most commonly used modern terms are "developmental dysplasia of the hip" or DDH and "congenital hip dislocation," CDH. Archaic terms include "congenital dislocation," "congenital hip," or "congenital subluxation of the hip" or "congenital dysplasia of the hip." Even with controlled vocabularies, each database uses a different subject term, for example, Medline's (Medical Subject Headings or MESH) heading is "Hip Dislocation, Congenital," EMBASE uses "Congenital Hip Dislocation," Web of Science uses "Congenital Dislocation," and the historical Index-Catalogue uses "Hip Joint, Dislocation of, Congenital."

The databases used in this paper were PubMed Medline (1947-2010) (http://www.ncbi.nlm.nih.gov/pubmed/), Ovid Medline (1947-2010), EMBASE (1987-2010), WorldCat (1880-2010) (books and theses) (http://firstsearch.oclc.org/), Web of Knowledge (1987-2010), and IndexCat (Index Catalogue of the Library of the Surgeon-General's Office (1880-1961) (http://www.indexcat.nlm.nih.gov/). Individual orthopedic journals were also searched for articles published prior to 1966 that predate electronic indexing, including Journal of Bone and Joint Surgery (American and British), Clinical Orthopaedics and Related Research, and Acta Orthopaedica Scandinavica. Hand searching and citation searching were also performed. Google Scholar (1880-2010) (http://scholar.google.com) was searched as a final check but did not find any additional articles. Age groups were limited to those $<18$ years old; duplicate citations were removed.

This search resulted in 2277 unique manuscripts which were reviewed to find those that discussed any of the topics regarding DDH and epidemiology, etiology, demographics, incidence, prevalence, race, gender, family history, inheritance, genetics, age, bone age, weight (either birth weight or normal weight), height, growth, maturation, any other anthropometric characteristics, seasonal variation, hormone, endocrine, congenital anomalies, perinatal factors, swaddling, collagen, and opposite hip. Of these 2277 manuscripts, 422 provided ample information and are the contents of this paper.

\section{Results}

\subsection{Childhood Hip Dysplasia}

Incidence. There are three eras in modern medicine when the incidence of hip DDH has been determined [26]. Period I (1920s to 1950s) was when the incidence was arbitrarily estimated. Period II (1950s to 1980s) was when the incidence was determined based on the detection of unstable hips on neonatal physical exam plus the addition of late-diagnosed patients. Period III (1980s to present) incorporates hip ultrasonography (both diagnostic and screening) (Figure 1).
Generally accepted ranges for the incidence of DDH for Period I range from $0-40 \%$ ( $0 \%$ Africans and up to $40 \%$ in other racial groups), for Period II $0.04 \%-16.8 \%$ ( $0 \%$ in Africans and up to $33 \%$ in Native Americans), and for Period III $4.4 \%-51.8 \%$ (4.4\% for Africans and $7.15 \%$ the lowest for Caucasians) [26]. The wide range of DDH incidence in Period III reflects differences in the definition of DDH. Some studies include any hips with ultrasonographic instability, whereas others include only those types $\geq$ Graf IIb (Table 1 , Figure 1).

Hip ultrasonography creates confusion due to differences between the neonatal physical exam and ultrasound findings $[15-17,27,28]$. The interobserver variability $(\kappa 0.4$ to 0.5$)$ in determining hip stability is also poor to moderate [29-31]. The wide variability in incidence in the ultrasonographic era is better understood when considering two different groups of neonatal instability. The first is neonatal, sonographic DDH which resolves spontaneously. The second is neonatal instability which if left untreated may progress to true DDH, ranging from acetabular dysplasia to complete dislocation. Hadlow [32] noted that 50\% of unstable hips at birth stabilized completely within 5 days; Barlow [33] noted that $90 \%$ of unstable hips at birth become normal by 2 months; Abdinejad et al. [34] noted that $97 \%$ of neonatally unstable hips resolved spontaneously by 6 months. Many of the sonographic DDH hips likely reflect these clinical findings $[20,32-34]$ and are in the first group.

The incidence/prevalence is quoted as the number per 1000 live births. The data presented here is a best attempt at synthesizing the literature during these different periods; insufficient data was often present making it difficult to calculate demographic variables. Race is classified using the definitions of Eveleth and Tanner: Caucasians, Africans in Africa and of African Ancestry, Asiatics (Amerindians, Hispanics, Indonesian-Malays), Indo-Mediterraneans (inhabitants of the Near East, North Africa, and Indian subcontinent), and Australian Aborigines and Pacific Island peoples [35].

\subsection{Clinical Screening Period (1950s-1980s) by Ethnic Groups (Table 2)}

\subsubsection{Conventional DDH}

\section{Indigenous Peoples (Table 2(a))}

(i) Native Americans. The incidence of DDH is high in Native Americans, likely due to a combination of genetics and swaddling. In the Arizona Fort Apache Indians [43], the incidence was 31, but likely higher, since cases of dysplasia and subluxation were excluded. This particular group of Native Americans represent a very tight gene pool as they have maintained their endogamous marriages (band members only marrying within their own band) after migrating approximately 600 years ago from three different bands in Western Canada. In Navajo children [42] from Fort Defiance, Arizona and Gallup, New Mexico, the incidence was 67 . A positive family history was present in $33 \%$ of the dysplasia cases but only $6.1 \%$ of the nondysplastic cases. In the Navajo from the Arizona Many Farms District, [41] 


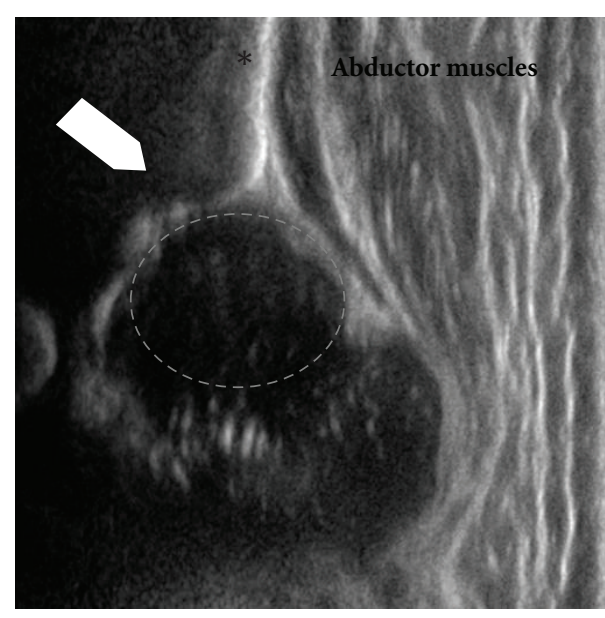

(a)

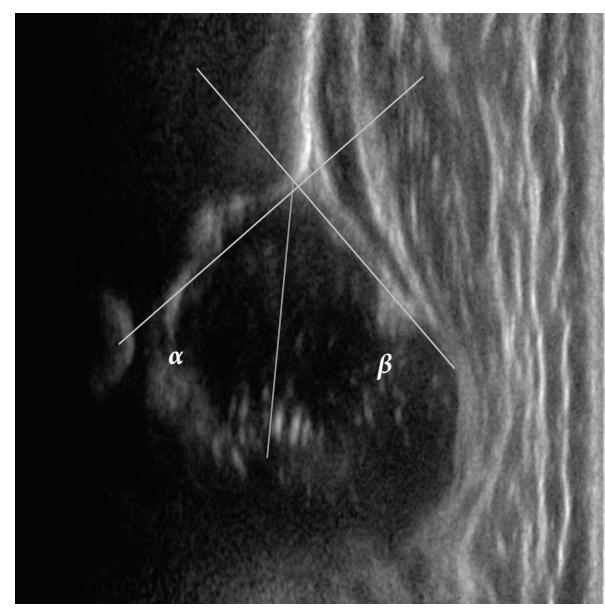

(c)

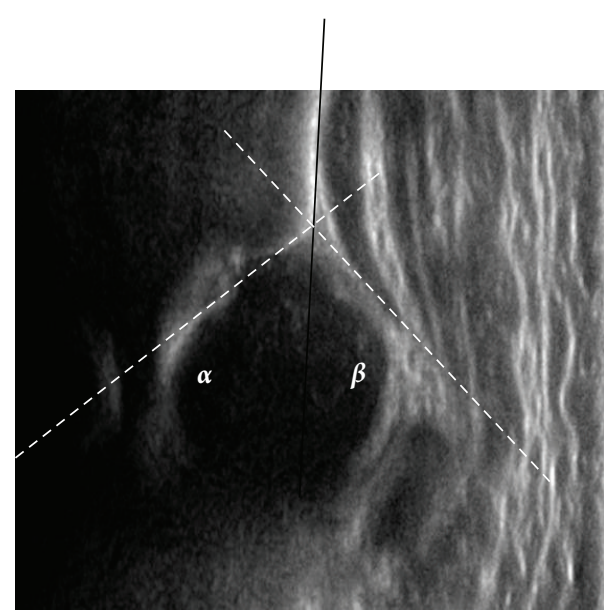

(b)

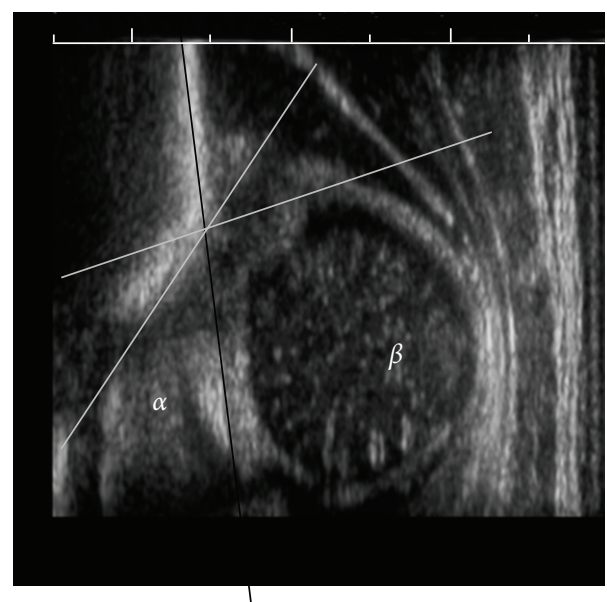

(d)

Figure 1: Ultrasound neonatal hip examination. (a) A representative longitudinal ultrasound image of a normal neonatal hip. The ilium is marked by the asterisk, the bony acetabular roof by the large arrowhead, and the abductor muscles seen by the longitudinal white/gray alternating structures. (b) Measurement of the alpha $(\alpha)$ and beta $(\beta)$ angles on ultrasound establish the Graf class. The baseline is first drawn and is the line along the ilium as it intersects the bony and cartilaginous portions of the acetabulum (solid black line). The $\alpha$ angle is the angle between the baseline and the roof of the bony acetabulum; the $\beta$ angle is the angle between the baseline and the cartilaginous roof. (c) An example of a Graf IIc hip, with an $\alpha$ angle of $43^{\circ}$ and a $\beta$ angle of $49^{\circ}$. (d) An example of a Graf IV hip, irreducible dislocated hip, with an $\alpha$ angle of $42^{\circ}$. Typically $\beta$ angles are not measured on dislocated hips, but in this example it would measure $99^{\circ}$.

TABLE 1: Graf's classification of hip dysplasia using ultrasound.

\begin{tabular}{|c|c|c|c|c|}
\hline Graf's hip type & Description & $\alpha$ angle $\left({ }^{\circ}\right)$ & $\beta$ angle $\left(^{\circ}\right)$ & Age \\
\hline I & Normal & $>60$ & $<55$ & Any \\
\hline IIa & Physiologically immature & $50-60$ & $55-77$ & $0-12$ wks \\
\hline IIb & Immature & $50-59$ & $55-77$ & $>12 \mathrm{wks}$ \\
\hline IIc & Acetabular deficiency & $43-49$ & $>77$ & Any \\
\hline IId & Everted labrum with subluxation & $43-49$ & $>77$ & Any \\
\hline III & Everted labrum with dislocation & $<43$ & $>77$ & Any \\
\hline IV & Dislocation & $<43$ & $>77$ & Any \\
\hline
\end{tabular}

As described by Graf [23], Roposch et al. [24], and Herring [25]. 


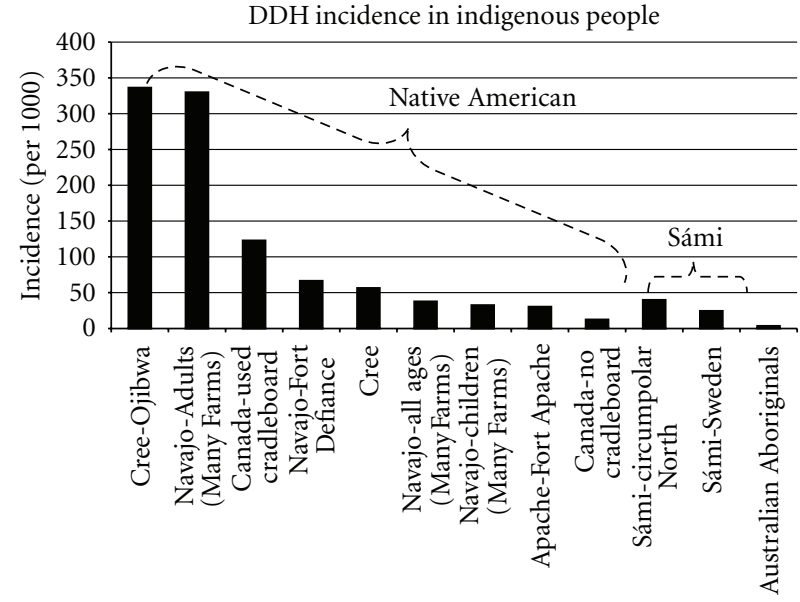

Population group

(a)

DDH incidence in Indo-Malays

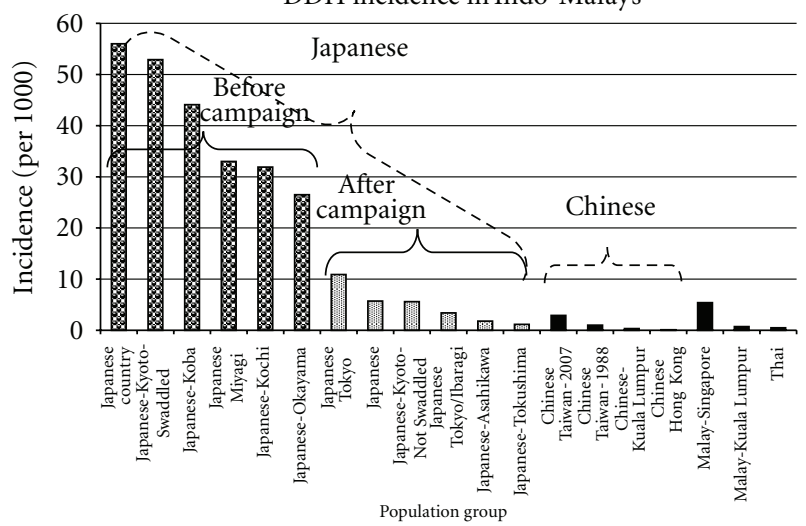

(c)

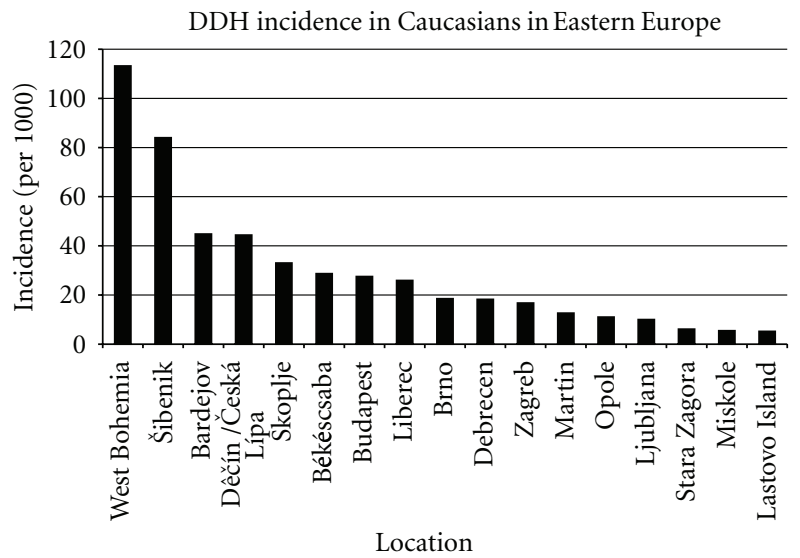

(e)

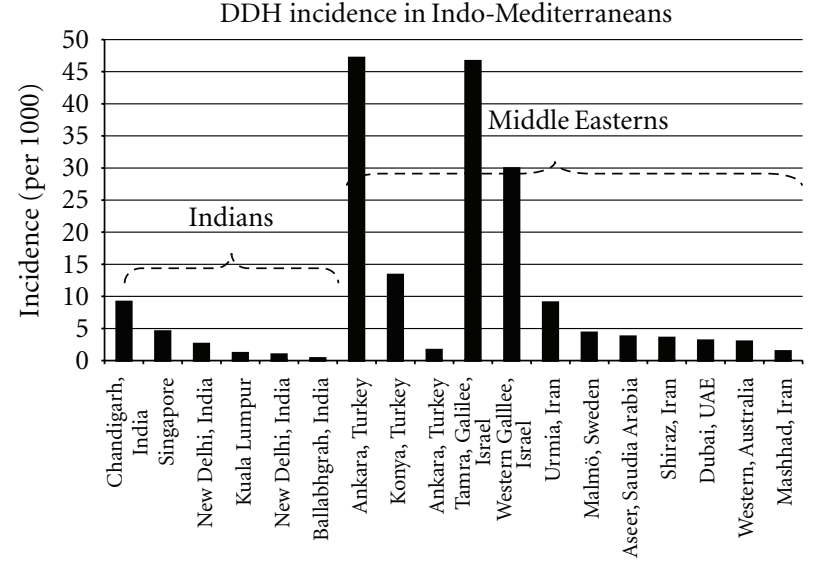

Population group

(b)

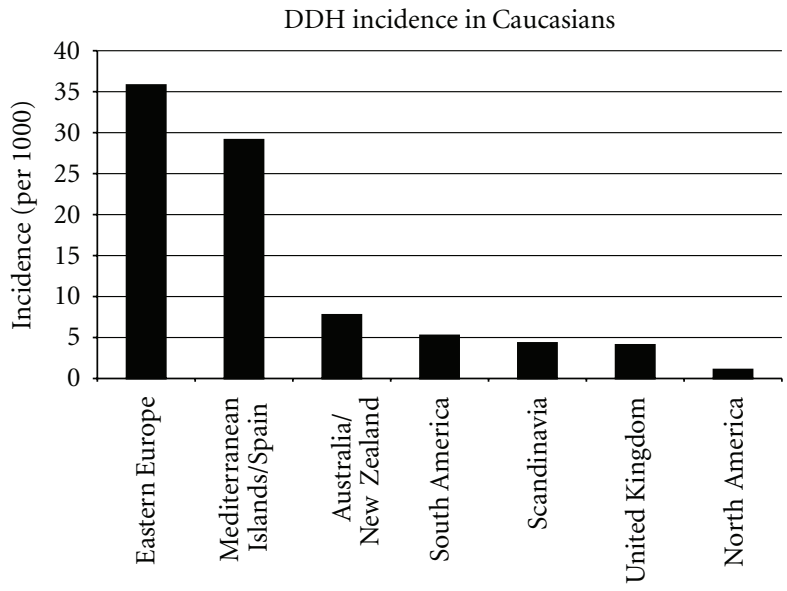

Population group

(d)

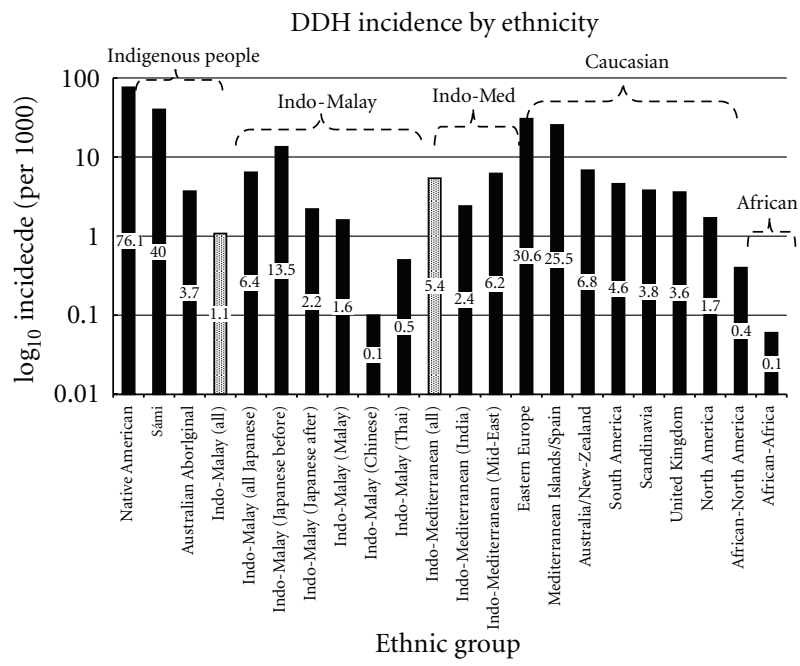

(f)

FIgURE 2: The incidence of DDH in various ethnic groups. (a) The incidence of DDH in indigenous populations. (b) DDH incidence in Indo-Mediterraneans. (c) DDH incidence in Indo-Malay peoples. (d) DDH incidence in all Caucasians. (e) DDH incidence in Eastern European Caucasians. (f) Incidence of DDH amongst all ethnic groups; note the $y$-axis is logarithmic con $_{10}$. 
TABLE 2: Incidence of DDH in the clinical screening period era (1950s-1980s).

(a) Indigenous peoples

\begin{tabular}{|c|c|c|c|c|c|c|c|}
\hline Study & Year & Location & Ethnicity & $\mathrm{Dx}$ & No. Pts & No. DDH & $\begin{array}{l}\text { Incidence } \\
\text { (per 1000) }\end{array}$ \\
\hline \multicolumn{8}{|l|}{$\begin{array}{l}\text { Native } \\
\text { Americans }\end{array}$} \\
\hline $\begin{array}{l}\text { Corrigan and } \\
\text { Segal }[36]\end{array}$ & 1950 & $\begin{array}{c}\text { Island Lake, } \\
\text { Manitoba }\end{array}$ & Cree-Ojibwa & Documented DDH & 1253 & 45 & 35.9 \\
\hline \multirow[t]{4}{*}{ Walker [37] } & 1977 & $\begin{array}{c}\text { Island Lake, } \\
\text { Manitoba }\end{array}$ & Cree-Ojibwa & All DDH & 1248 & 420 & 336.5 \\
\hline & & & & Dislocation & & 243 & 194.7 \\
\hline & & & & Dysplasia & & 123 & 98.6 \\
\hline & & & & Other & & 54 & 43.3 \\
\hline \multirow[t]{2}{*}{$\begin{array}{l}\text { Houston and } \\
\text { Buhr [38] }\end{array}$} & 1966 & $\begin{array}{c}\text { Northern } \\
\text { Saskatchewan }\end{array}$ & Cree & All DDH & 4453 & 59 & 13.2 \\
\hline & & & & Likely DDH & 1253 & 71 & 56.7 \\
\hline \multirow[t]{3}{*}{ Salter [39] } & 1968 & $\begin{array}{l}\text { Ontario, } \\
\text { Canada }\end{array}$ & - & All DDH & & & \\
\hline & & & & Used cradleboard & 2032 & 250 & 123.0 \\
\hline & & & & No cradleboard & 1347 & 17 & 12.6 \\
\hline \multirow[t]{9}{*}{$\begin{array}{l}\text { Rabin et al. } \\
{[40]}\end{array}$} & 1965 & $\begin{array}{l}\text { Many Farms } \\
\text { District, AZ }\end{array}$ & Navajo & Adults-All & 270 & 9 & 33.3 \\
\hline & & & & Dislocation & & 7 & 25.9 \\
\hline & & & & Dysplasia & & 2 & 7.4 \\
\hline & & & & Children-All & 548 & 22 & 40.1 \\
\hline & & & & Dislocation & & 4 & 7.3 \\
\hline & & & & Dysplasia & & 18 & 32.8 \\
\hline & & & & Adults and Children-All & 818 & 31 & 37.9 \\
\hline & & & & Dislocation & & 11 & 13.4 \\
\hline & & & & Dysplasia & & 20 & 24.4 \\
\hline \multirow[t]{8}{*}{$\begin{array}{l}\text { Pratt et al. } \\
{[41]}\end{array}$} & 1982 & $\begin{array}{l}\text { Many Farms } \\
\text { District, AZ }\end{array}$ & Navajo & Children & & & \\
\hline & & & & All DDH & 548 & 18 & 32.8 \\
\hline & & & & Dislocation & & 14 & 25.5 \\
\hline & & & & Dysplasia & & 4 & 7.3 \\
\hline & & & & Adults & & & \\
\hline & & & & All DDH & 270 & 89 & 330 \\
\hline & & & & Dislocation & & 70 & 259 \\
\hline & & & & Dysplasia & & 19 & 70 \\
\hline Coleman [42] & 1968 & $\begin{array}{c}\text { Fort } \\
\text { Defiance, } \\
\text { Ship Rock, } \\
\text { Gallup }\end{array}$ & Navajo & All DDH $\leq 3$ months old & 1155 & 77 & 66.7 \\
\hline $\begin{array}{l}\text { Kraus and } \\
\text { Schwartzman } \\
{[43]}\end{array}$ & 1957 & Fort Apache & Apache & Dislocation & 3500 & 107 & 30.6 \\
\hline Weighted avg. & & & & All DDH & 14553 & 1108 & 76.1 \\
\hline \multicolumn{8}{|l|}{$\begin{array}{l}\text { Sámi and } \\
\text { Australian } \\
\text { Aboriginals }\end{array}$} \\
\hline $\begin{array}{l}\text { Bower et al. } \\
{[44]}\end{array}$ & 1987 & $\begin{array}{c}\text { Western } \\
\text { Australia }\end{array}$ & Australian Aboriginals & All DDH & $*$ & 22 & 37 \\
\hline
\end{tabular}


(a) Continued.

\begin{tabular}{lcccccc}
\hline Study & Year & Location & Ethnicity & Dx & No. Pts & No. DDH \\
\hline Getz [45] & 1955 & $\begin{array}{c}\text { Sámpi } \\
\text { Circumpolar } \\
\text { Europe })\end{array}$ & Sámi & All DDH & $*$ & 40 \\
Mellbin [46] & 1962 & Sweden & Sámi & All DDH & 813 & 20 \\
\hline
\end{tabular}

(b) Africans, Indo-Mediterranean, and mixed peoples

\begin{tabular}{|c|c|c|c|c|c|c|}
\hline Study & Year & Location & Ethnicity & No. Pts & No. DDH & $\begin{array}{l}\text { Incidence } \\
\text { (per 1000) }\end{array}$ \\
\hline \multicolumn{7}{|l|}{$\begin{array}{l}\text { Africans- } \\
\text { Blacks }\end{array}$} \\
\hline Edelsetin [47] & 1966 & South Africa & Bantu & 16678 & 0 & 0 \\
\hline Roper [48] & 1976 & $\begin{array}{l}\text { Rhodesia } \\
\text { (Zimbabwe) }\end{array}$ & Bantu & 40000 & 1 & 0.025 \\
\hline $\begin{array}{l}\text { Pompe van } \\
\text { Meerdervoort } \\
{[49]}\end{array}$ & 1977 & South Africa & - & 10000 & 3 & 0.3 \\
\hline Weighted avg. & & & & 66678 & 4 & 0.06 \\
\hline Burke et al. [50] & 1985 & United States & - & $28261^{*}$ & 13 & 0.46 \\
\hline Finley et al. [51] & 1994 & $\begin{array}{l}\text { Jefferson } \\
\text { County, } \\
\text { Alabama, } \\
\text { USA }\end{array}$ & - & 9654 & 2 & 0.2 \\
\hline Weighted avg. & & & & 37915 & 15 & 0.40 \\
\hline \multicolumn{7}{|l|}{$\begin{array}{l}\text { Indo- } \\
\text { Mediterranean }\end{array}$} \\
\hline $\begin{array}{l}\text { Kulshrestha et } \\
\text { al. [52] }\end{array}$ & 1983 & $\begin{array}{l}\text { Ballabhgarh, } \\
\text { India }\end{array}$ & Indian & 2409 & 1 & 0.42 \\
\hline $\begin{array}{l}\text { Singh and } \\
\text { Sharma [53] }\end{array}$ & 1980 & $\begin{array}{l}\text { New Delhi, } \\
\text { India }\end{array}$ & Indian & 7274 & 7 & 1.0 \\
\hline $\begin{array}{l}\text { Boo and } \\
\text { Rajaram [54] }\end{array}$ & 1984 & $\begin{array}{l}\text { Kuala } \\
\text { Lumpur }\end{array}$ & Indian & 8109 & 10 & 1.23 \\
\hline Gupta et al. [55] & 1992 & $\begin{array}{l}\text { New Delhi, } \\
\text { India }\end{array}$ & Indian & 6209 & 16 & 2.65 \\
\hline Ang et al. [56] & 1997 & Singapore & Indian & 2810 & 13 & 4.6 \\
\hline $\begin{array}{l}\text { Kaushal et al. } \\
\text { [57] }\end{array}$ & 1976 & $\begin{array}{l}\text { Chandigarh, } \\
\text { Northern } \\
\text { India }\end{array}$ & Indian & 2500 & 23 & 9.2 \\
\hline Şahin et al. [58] & 2004 & $\begin{array}{l}\text { Ankara, } \\
\text { Turkey }\end{array}$ & Turkish & 5798 & 10 & 1.7 \\
\hline Kutlu et al. [59] & 1992 & $\begin{array}{l}\text { Konya, } \\
\text { Turkey }\end{array}$ & Turkish & 4173 & 56 & 13.4 \\
\hline Doğruel [60] & 2008 & $\begin{array}{l}\text { Ankara, } \\
\text { Turkey }\end{array}$ & Turkish & 3541 & 167 & 47.2 \\
\hline Alkalay [61] & 1972 & $\begin{array}{l}\text { Tamra, } \\
\text { Galilee, Israel }\end{array}$ & Arabic & 450 & 21 & 46.7 \\
\hline Alkalay [61] & 1972 & $\begin{array}{l}\text { Western } \\
\text { Galilee, Israel }\end{array}$ & Arabic/Druze & 3625 & 109 & 30.0 \\
\hline $\begin{array}{l}\text { Moosa et al. } \\
{[62]}\end{array}$ & 2009 & Dubai, UAE & Arabic & 3786 & 12 & 3.17 \\
\hline Mirdad [63] & 2002 & $\begin{array}{l}\text { Aseer, Saudi } \\
\text { Arabia }\end{array}$ & Saudi & 79548 & 300 & 3.8 \\
\hline
\end{tabular}


(b) Continued.

\begin{tabular}{|c|c|c|c|c|c|c|}
\hline Study & Year & Location & Ethnicity & No. Pts & No. DDH & $\begin{array}{l}\text { Incidence } \\
\text { (per 1000) }\end{array}$ \\
\hline Danielsson [64] & 2000 & $\begin{array}{l}\text { Malmö, } \\
\text { Sweden }\end{array}$ & Iraqi/Iranian & 1604 & 7 & 4.4 \\
\hline $\begin{array}{l}\text { Mamouri et al. } \\
\text { [65] }\end{array}$ & 2004 & $\begin{array}{l}\text { Mashhad, } \\
\text { Iran }\end{array}$ & Iranian & 6576 & 10 & 1.5 \\
\hline $\begin{array}{l}\text { Abdinejad et al. } \\
\text { [34] }\end{array}$ & 1996 & Shiraz, Iran & Iranian & 8024 & 30 & 3.6 \\
\hline $\begin{array}{l}\text { Pashapour and } \\
\text { Golmaham- } \\
\text { madlou [66] }\end{array}$ & 2007 & Urmia, Iran & Iranian & 1100 & 10 & 9.1 \\
\hline Paterson [67] & 1976 & $\begin{array}{l}\text { Western } \\
\text { Australia }\end{array}$ & $\begin{array}{l}\text { Indo-Mediterra- } \\
\text { nean, not } \\
\text { otherwise } \\
\text { specified }\end{array}$ & 2964 & 9 & 3.0 \\
\hline \multirow{3}{*}{ Weighted avg. } & & & All & 150500 & 811 & 5.4 \\
\hline & & & Indian & 29311 & 70 & 2.4 \\
\hline & & & Arabic & 118225 & 732 & 6.2 \\
\hline \multicolumn{7}{|l|}{$\begin{array}{l}\text { Mixed/ } \\
\text { Unknown-All } \\
\text { Geographic } \\
\text { Locations }\end{array}$} \\
\hline $\begin{array}{l}\text { Rao and } \\
\text { Thurston [68] }\end{array}$ & 1986 & $\begin{array}{l}\text { Wellington, } \\
\text { New Zealand }\end{array}$ & Not specified & 15174 & 60 & 4.0 \\
\hline \multirow[t]{2}{*}{ Lowry et al. [69] } & 1989 & $\begin{array}{l}\text { Alberta, } \\
\text { Canada }\end{array}$ & North America & $813^{@}$ & 30347 & 2.68 \\
\hline & & & Not specified & 34956 & 342 & 9.8 \\
\hline \multirow[t]{2}{*}{$\begin{array}{l}\text { Medalie et al. } \\
{[70]}\end{array}$} & 1966 & $\begin{array}{l}\text { Jerusalem, } \\
\text { Israel }\end{array}$ & Dislocation & & 107 & 3.1 \\
\hline & & & Subluxation & & 235 & 6.7 \\
\hline $\begin{array}{l}\text { Harlap et al. } \\
{[71]}\end{array}$ & 1971 & $\begin{array}{l}\text { Jerusalem, } \\
\text { Israel }\end{array}$ & Jewish/Arabic & 18017 & 104 & 5.7 \\
\hline
\end{tabular}

@ calculated from the given incidence and total number of births.

(c) Indo-Malay peoples

\begin{tabular}{|c|c|c|c|c|c|c|}
\hline Study & Year & Location & Ethnicity & No. Pts & No. DDH & Incidence (per 1000) \\
\hline $\begin{array}{l}\text { Huang et al. } \\
\text { [72] }\end{array}$ & 1988 & Taiwan & Chinese & 9884 & 10 & 1.01 \\
\hline Chang et al. [73] & 2007 & Taiwan & Chinese & $*$ & $*$ & 2.9 \\
\hline $\begin{array}{l}\text { Hoaglund et al. } \\
{[74]}\end{array}$ & 1981 & Hong Kong & Chinese & 557683 & 38 & 0.07 \\
\hline $\begin{array}{l}\text { Boo and } \\
\text { Rajaram [54] }\end{array}$ & 1984 & Kuala Lumpur & Chinese & 12115 & 4 & 0.33 \\
\hline $\begin{array}{l}\text { Limpaphayom } \\
{[75,76]}\end{array}$ & 1975 & Thailand & Thai & 33433 & 17 & 0.5 \\
\hline Ang et al. [56] & 1997 & Singapore & Malay & 7439 & 40 & 5.4 \\
\hline $\begin{array}{l}\text { Boo and } \\
\text { Rajaram [54] }\end{array}$ & 1984 & Kuala Lumpur & Malay & 29695 & 21 & 0.71 \\
\hline \multicolumn{7}{|l|}{$\begin{array}{l}\text { Japanese- } \\
\text { before } \\
\text { Educational/ } \\
\text { Prevention } \\
\text { Campaigns }\end{array}$} \\
\hline Naito [77] & 1958 & Japan & Japanese & * & * & 56.0 \\
\hline Akabayashi [78] & 1958 & Miyagi, Japan & Japanese & & & 33.0 \\
\hline Tsuji [79] & 1964 & Tokyo, Japan & Japanese & & & 11.9 \\
\hline $\begin{array}{l}\text { Kashiwagi and } \\
\text { Kagawa [80] }\end{array}$ & 1965 & Kobe, Japan & Japanese & 929 & 41 & 44.1 \\
\hline
\end{tabular}


(c) Continued.

\begin{tabular}{|c|c|c|c|c|c|c|}
\hline Study & Year & Location & Ethnicity & No. Pts & No. DDH & Incidence (per 1000) \\
\hline Haginomori [81] & 1966 & Kochi, Japan & Japanese & 3323 & 106 & 31.9 \\
\hline \multirow[t]{4}{*}{ Tanabe et al. [82] } & 1972 & Okayama, Japan & Japanese & & & \\
\hline & & & All & 2756 & 73 & 26.5 \\
\hline & & & Dislocation & & 32 & 11.6 \\
\hline & & & Subluxation & & 41 & 14.9 \\
\hline Wada et al. [83] & 1993 & Tokushima Prefecture, & Japanese & & & $22 *$ \\
\hline Ishida [84] & 1993 & Aichi & Japanese & & & $11.2^{*}$ \\
\hline Ishida [84] & 1993 & Fukushima & Japanese & & & $18^{*}$ \\
\hline Ishida [84] & 1993 & Osaka & Japanese & & & $8^{*}$ \\
\hline Ishida [85] & 1993 & Kyoto & Japanese & & & $28^{*}$ \\
\hline Kikuike et al. [86] & 1993 & Takayama/Gifu & Japanese & 2289 & 25 & 10.9 \\
\hline Gotoh et al. [87] & 1993 & Asahikawa & Japanese & 15944 & 95 & 6 \\
\hline Saito $[88]$ & 1993 & Sapporo & Japanese & & & $12^{*}$ \\
\hline Shinohara [89] & 1993 & Matsudo & Japanese & & & $5.1^{*}$ \\
\hline $\begin{array}{l}\text { Iwasaki and } \\
\text { Takahashi [90] }\end{array}$ & 1993 & Nagasaki & Japanese & & & $6.3^{*}$ \\
\hline \multicolumn{7}{|l|}{$\begin{array}{l}\text { Japanese- } \\
\text { Seminal Study on } \\
\text { Effects of } \\
\text { Extension } \\
\text { Diaper- } \\
\text { ing/Swaddling }\end{array}$} \\
\hline & & & Japanese & & & \\
\hline \multirow[t]{2}{*}{ Ishida [85] } & 1977 & Kyoto, Japan & Swaddled & 3778 & 200 & 52.9 \\
\hline & & & Not swaddled & 3047 & 17 & 5.6 \\
\hline \multicolumn{7}{|l|}{$\begin{array}{l}\text { Japanese-after } \\
\text { Educa- } \\
\text { tional/Prevention } \\
\text { Campaigns }\end{array}$} \\
\hline Higuchi [91] & 1984 & Tokyo and Ibaragi Prefecture & Japanese & 13379 & 45 & 3.4 \\
\hline Wada et al. [83] & 1993 & Tokushima Prefecture, & Japanese & 17224 & 20 & 1.2 \\
\hline Ishida [84] & 1993 & Aichi & Japanese & & & $1.1^{*}$ \\
\hline Ishida [84] & 1993 & Fukushima & Japanese & & & $5^{*}$ \\
\hline Ishida [84] & 1993 & Osaka & Japanese & & & $3^{*}$ \\
\hline Ishida [85] & 1993 & Kyoto & Japanese & & & $3^{*}$ \\
\hline Kikuike et al. [86] & 1993 & Takayama/Gifu & Japanese & 1749 & 10 & 5.7 \\
\hline Gotoh et al. [87] & 1993 & Asahikawa & Japanese & 9471 & 17 & 1.8 \\
\hline Saito $[88]$ & 1993 & Sapporo & Japanese & & & $5.0^{*}$ \\
\hline Shinohara [89] & 1993 & Matsudo & Japanese & & & $1.8^{*}$ \\
\hline \multirow[t]{3}{*}{$\begin{array}{l}\text { Iwasaki and } \\
\text { Takahashi [90] }\end{array}$} & 1993 & Nagasaki & Japanese & & & $2.0^{*}$ \\
\hline & & & All & 714254 & 769 & 1.08 \\
\hline & & & Chinese & 57962 & 52 & 0.1 \\
\hline \multirow[t]{4}{*}{ Weighted avg. } & & & Malay & 37134 & 61 & 1.6 \\
\hline & & & Japanese & & & \\
\hline & & & Before & 25241 & 340 & 13.5 \\
\hline & & & After & 41823 & 92 & 2.2 \\
\hline
\end{tabular}

${ }^{\wedge}$ Incidence from [82].

* Only the incidence was given and could not be included in the weighted averages. 
(d) Caucasians

\begin{tabular}{|c|c|c|c|c|c|}
\hline Study & Year & Location & No. Pts & No. DDH & $\begin{array}{l}\text { Incidence } \\
\text { (per 1000) }\end{array}$ \\
\hline \multicolumn{6}{|l|}{ Scandinavia } \\
\hline Severin [92] & 1956 & All Sweden & 566142 & 497 & 0.88 \\
\hline von Rosen [93] & 1962 & Malmö, Sweden & 24000 & 40 & 1.7 \\
\hline von Rosen [94] & 1968 & Malmö, Sweden & 31304 & 171 & 5.46 \\
\hline Fredensborg [95] & 1976 & Malmö, Sweden & 58579 & 548 & 9.33 \\
\hline Danielsson [64] & 2000 & Malmö, Sweden & 15189 & 115 & 7.57 \\
\hline Beckman et al. [96] & 1977 & Northern Sweden & 40419 & 295 & 7.30 \\
\hline Finley et al. [51] & 1984 & Uppsala, Sweden & $62879^{*}$ & 193 & 28.0 \\
\hline Bjerkeim [97-102] & 1974,1976 & $\begin{array}{l}\text { Southeastern } \\
\text { Norway }\end{array}$ & $*$ & * & 10.0 \\
\hline Finne et al. [103] & 2008 & Oslo, Norway & 19820 & 34 & 1.7 \\
\hline $\begin{array}{l}\text { Melve and } \\
\text { Skjaerven [104] }\end{array}$ & 2008 & All Norway & 519266 & 2509 & 4.83 \\
\hline Heikkilä [105] & 1984 & Southern Finland & 151924 & 1035 & 6.81 \\
\hline $\begin{array}{l}\text { Clausen and } \\
\text { Nielsen [106] }\end{array}$ & 1988 & Randers, Denmark & 13589 & 83 & 6.1 \\
\hline Weighted avg. & & & 1510007 & 5713 & 3.8 \\
\hline \multicolumn{6}{|l|}{ Western Europe } \\
\hline Mitchell [107] & 1972 & $\begin{array}{l}\text { Edinburgh, } \\
\text { Scotland }\end{array}$ & 31961 & 100 & 3.1 \\
\hline $\begin{array}{l}\text { MacKenzie and } \\
\text { Wilson [108] }\end{array}$ & 1981 & Aberdeen, Scotland & 53033 & 1606 & 30.3 \\
\hline Bertol et al. [109] & 1982 & $\begin{array}{l}\text { Edinburgh, } \\
\text { Scotland }\end{array}$ & 44953 & 299 & 6.7 \\
\hline $\begin{array}{l}\text { Record and } \\
\text { Edwards [110] }\end{array}$ & 1958 & $\begin{array}{l}\text { Birmingham, } \\
\text { England }\end{array}$ & 226038 & 148 & 0.66 \\
\hline Leck et al. [111] & 1968 & $\begin{array}{l}\text { Birmingham, } \\
\text { England }\end{array}$ & 94474 & 86 & 0.91 \\
\hline Wilkinson [112] & 1972 & $\begin{array}{l}\text { Southampton, } \\
\text { England }\end{array}$ & 6272 & 37 & 5.9 \\
\hline Jones [113] & 1977 & $\begin{array}{l}\text { Hertfordshire, } \\
\text { England }\end{array}$ & 29366 & 76 & 2.6 \\
\hline Noble et al. [114] & 1978 & $\begin{array}{l}\text { Newcastle upon } \\
\text { Tyne, England }\end{array}$ & 25921 & 271 & 10.5 \\
\hline Catford et al. [115] & 1982 & $\begin{array}{l}\text { Southampton, } \\
\text { England }\end{array}$ & 76724 & 178 & 2.32 \\
\hline Knox et al. [116] & 1987 & $\begin{array}{l}\text { Birmingham, } \\
\text { England }\end{array}$ & 144246 & 96 & 0.67 \\
\hline Williamson [117] & 1972 & Northern Ireland & 34840 & 97 & 2.78 \\
\hline $\begin{array}{l}\text { Patterson et al. } \\
\text { [118] }\end{array}$ & 1995 & $\begin{array}{l}\text { Belfast, Northern } \\
\text { Ireland }\end{array}$ & 138600 & 243 & 1.75 \\
\hline Reerink [119] & 1993 & $\begin{array}{l}\text { Leiden, } \\
\text { Netherlands }\end{array}$ & 2092 & 32 & 15.3 \\
\hline $\begin{array}{l}\text { Judet and Tanzy } \\
{[120]}\end{array}$ & 1966 & $\begin{array}{l}\text { Creuse, France } \\
\text { (only girls) }\end{array}$ & 1326 & 48 & 3.6 \\
\hline
\end{tabular}


(d) Continued.

\begin{tabular}{|c|c|c|c|c|c|}
\hline Study & Year & Location & No. Pts & No. DDH & $\begin{array}{l}\text { Incidence } \\
\text { (per 1000) }\end{array}$ \\
\hline $\begin{array}{l}\text { Valdivieso Garcia } \\
\text { et al. [121] }\end{array}$ & 1989 & Córdoba, Spain & 33000 & 323 & 9.79 \\
\hline \multirow[t]{5}{*}{$\begin{array}{l}\text { Padilla-Esteban et } \\
\text { al. [122] }\end{array}$} & 1990 & Madrid, Spain & 40243 & & \\
\hline & & All & & 1747 & 43.4 \\
\hline & & Dislocation & & 89 & 2.21 \\
\hline & & Subluxation & & 80 & 1.99 \\
\hline & & Dysplasia & & 1587 & 39.4 \\
\hline Sanz et al. [123] & 1991 & Salamanca, Spain & 6135 & 54 & 8.8 \\
\hline $\begin{array}{l}\text { Giannakopoulou et } \\
\text { al. [124] }\end{array}$ & 2002 & Crete & 6140 & 65 & 10.6 \\
\hline \multirow[t]{2}{*}{ Di Bella et al. [125] } & 1997 & Sicily & 2000 & 51 & 25.5 \\
\hline & & All & 996038 & 5509 & 5.5 \\
\hline \multirow[t]{2}{*}{ Weighted avg. } & & United Kingdom & 906428 & 3232 & 3.6 \\
\hline & & $\begin{array}{l}\text { Mediterranean/ } \\
\text { Spain }\end{array}$ & 87518 & 2240 & 25.5 \\
\hline \multicolumn{6}{|l|}{ Eastern Europe } \\
\hline Srakar [126] & 1986 & $\begin{array}{l}\text { Ljubljana, } \\
\text { Yugoslavia }\end{array}$ & 5000 & $50^{@}$ & 10.0 \\
\hline Kepeski et al. [127] & 1969 & $\begin{array}{l}\text { Skoplje, } \\
\text { Macedonia }\end{array}$ & 9149 & $302^{@}$ & 33.0 \\
\hline Maričević [128] & $1885-1993$ & $\begin{array}{l}\text { Lastovo Island, } \\
\text { Croatia }\end{array}$ & 3676 & 19 & 5.2 \\
\hline Krolo et al. [129] & $1968-88$ & Zagreb, Croatia & 7168 & 120 & 16.7 \\
\hline Stipanicev [130] & 1985 & Šibenik, Croatia & 26227 & $2203^{@}$ & 84.0 \\
\hline Darmonov [131] & 1996 & $\begin{array}{l}\text { Stara Zagora, } \\
\text { Bulgaria }\end{array}$ & 20417 & 124 & 6.1 \\
\hline $\begin{array}{l}\text { Samborska and } \\
\text { Lembrych [132] }\end{array}$ & 1973 & Opole, Poland & 14500 & 159 & 11.0 \\
\hline Polívka [133] & 1973 & $\begin{array}{l}\text { West Bohemia, } \\
\text { Czech Republic }\end{array}$ & 28471 & 3223 & 113.2 \\
\hline Košek [134] & 1973 & $\begin{array}{l}\text { Dêčín and Česká } \\
\text { Lípa, Czech } \\
\text { Republic }\end{array}$ & 23580 & 1048 & 44.4 \\
\hline Poul et al. [135] & 1992 & $\begin{array}{l}\text { Brno, } \\
\text { Czechoslovakia }\end{array}$ & 35550 & 656 & 18.5 \\
\hline $\begin{array}{l}\text { Vencálková and } \\
\text { Janata [136] }\end{array}$ & 2009 & $\begin{array}{l}\text { Liberec, Czech } \\
\text { Republic }\end{array}$ & 12944 & 335 & 25.9 \\
\hline Drimal [137] & 1959 & Martin, Slovakia & 9510 & 120 & 12.6 \\
\hline Tomáš [138] & 1989 & Bardejov, Slovakia & 7208 & 323 & 44.8 \\
\hline Czéizel et al. [139] & 1974 & $\begin{array}{l}\text { Békéscsaba, } \\
\text { Hungary }\end{array}$ & 18219 & 523 & 28.7 \\
\hline $\begin{array}{l}\text { Csató and } \\
\text { Benkó[140] }\end{array}$ & 1963 & Miskole, Hungary & 5513 & 30 & 5.44 \\
\hline Pap [141] & 1956 & $\begin{array}{l}\text { Debrecen, } \\
\text { Hungary }\end{array}$ & 11933 & 217 & 18.2 \\
\hline Czeizel et al. [142] & 1972 & Budapest, Hungary & 108966 & 3000 & 27.5 \\
\hline Weighted avg. & & & 348031 & 12452 & 35.8 \\
\hline \multicolumn{6}{|l|}{$\begin{array}{l}\text { Australia and New } \\
\text { Zealand }\end{array}$} \\
\hline Paterson [67] & 1976 & South Australia & 4445 & 31 & 7.0 \\
\hline Yiv et al. [143] & 1977 & South Australia & 19622 & 206 & 10.5 \\
\hline Bower et al. [44] & 1987 & Western Australia & $62879^{\wedge}$ & 415 & 6.6 \\
\hline
\end{tabular}


(d) Continued.

\begin{tabular}{|c|c|c|c|c|c|}
\hline Study & Year & Location & No. Pts & No. DDH & $\begin{array}{l}\text { Incidence } \\
\text { (per 1000) }\end{array}$ \\
\hline Chan et al. [144] & 1999 & Adelaide, Australia & 118379 & 916 & 7.74 \\
\hline $\begin{array}{l}\text { Howie and Phillips } \\
{[145]}\end{array}$ & 1970 & $\begin{array}{l}\text { Auckland, New } \\
\text { Zealand }\end{array}$ & 16103 & 57 & 3.54 \\
\hline $\begin{array}{l}\text { Doig and Shannon } \\
{[146]}\end{array}$ & 1975 & $\begin{array}{l}\text { Canterbury, New } \\
\text { Zealand }\end{array}$ & 23443 & 62 & 2.65 \\
\hline Dykes [147] & 1975 & $\begin{array}{l}\text { Southland, New } \\
\text { Zealand }\end{array}$ & 47064 & 103 & 2.19 \\
\hline Hadlow [32] & 1988 & $\begin{array}{l}\text { New Plymouth, } \\
\text { New Zealand }\end{array}$ & 20657 & 331 & 16.0 \\
\hline Weighted avg. & & & 312592 & 2121 & 6.8 \\
\hline \multicolumn{6}{|l|}{ Americas } \\
\hline $\begin{array}{l}\text { Lehmann and } \\
\text { Street [148] }\end{array}$ & 1981 & $\begin{array}{l}\text { Vancouver, British, } \\
\text { Columbia, Canada }\end{array}$ & 116808 & 142 & $1.2^{*}$ \\
\hline Tijmes et al. [149] & 1971 & Llanquihue, Chile & 30000 & 137 & 4.6 \\
\hline $\begin{array}{l}\text { Hazel and Beals } \\
{[150]}\end{array}$ & 1989 & Portland, Oregon & 39429 & 32 & 0.8 \\
\hline Finley et al. [51] & 1994 & $\begin{array}{l}\text { Jefferson County, } \\
\text { Alabama }\end{array}$ & 17907 & 12 & 0.7 \\
\hline Weighted avg. & & & 174144 & 186 & 1.07 \\
\hline
\end{tabular}

* The incidence and either the numerator/denominator were given; appropriate values calculated when possible.

${ }^{\circledR}$ calculated from the given incidence and total number of births.

the overall prevalence of DDH was $37.9: 33.3$ for adults and 40.1 for children. Complete dislocation was more common in adults and simple acetabular dysplasia/subluxation more common in children. The ratio of childhood dysplasia to dislocation was 4.5 to 1 and in adults 0.3 to 1 .

In an early study of the Cree-Ojibwa, Island Lake, Northern Manitoba, the incidence was 36 [36]; in a later more detailed study, the incidence of frank dislocation and subluxation was 110 [37]. The prevalence of DDH for all ages was 336 [37] (195 for frank hip dislocation or subluxation, 99 for dysplasia, and 54 for other types). In the Cree in Northern Saskatchewan, the overall prevalence was 13.2 [38]. In Ontario Native Americans [39], the incidence ranged from 12 to 123 . Using weighted averages, the average incidence of DDH in Native Americans is 76.1 for all dysplasia (Figure 2(a)).

(ii) Sámi and Australian Aboriginals. The Sámi (previously known as "Lapps" which is a derogatory offensive term) is the indigenous people of Sápmi, the circumpolar areas of Sweden, Norway, Finland, and the Kola Peninsula of Russia [151]. The Sámi population is 50,000 to 100,000 , and $\sim 1 / 2$ live in Norway [151-153]. The incidence of DDH in the Sámi was 24.6 [46] and 40 [45]. The incidence in Australian Aborigines is $\sim 1 / 2$ that of Caucasians (3.7 versus 6.6) [44] (Figure 2(a)).

(iii) Africans. DDH is extremely rare in Africans (Table 2(b)). In Sub-Saharan Africans, 2 cases of typical DDH were described in the Bantu [48]. There were no signs of hip dysplasia at 3 months of age in another study of 16678 Bantu children [47], despite breech presentation in 897 (5.4\%). In the Kikuyu Bantu, Kenya, 2 cases of typical DDH are described [154]. In a review of 284 children with congenital orthopaedic malformations in an African teaching hospital (Ibadan, Nigeria), DDH accounted for only $2.2 \%$ of all congenital malformations [155].

This immunity of the African infant from DDH may be due to deeper acetabulae [156], genetic factors [157], and the absence of swaddling in African cultures. Carrying the infant in an abducted position straddling the iliac crest is postulated as protective against DDH in the African peoples. However, in the United States, the acetabular indices of Caucasian and African infants showed minimal differences at birth but by 6 to 12 months of age were actually slightly higher (or shallower acetabulae) in Africans [158]. Genetic mixing between Africans and other races with a higher incidence of DDH (e.g., Caucasians in the United States) $[48,159]$ results in a higher but still comparatively low incidence of DDH. Quoted incidences in African Americans are 0.21 [51] and 0.46 [50] compared to 1.5 in American Caucasian infants [50]. Using weighted averages, the incidence of DDH is 0.06 in Africans in Africa and 0.40 in the United States.

(iv) Indo-Mediterraneans. The incidence in India is 0.42 in rural Ballabgarh, Haryana [52], 1.0 [53] and 2.65 [55] in New Delhi, and 9.2 in northern India (Chandigarh) [57]. For Indians in Malaysia, it is 1.2 [54] and 4.63 in Singapore [56]. In Iranians, it is 1.5 in Mashhad City [65], 3.64 in Shiraz [34], and 9.1 in Urmia [66]. In Dubai, UAE, the incidence is 3.17 [62] and 3.8 in Aseer, Saudi Arabia [63]. In Western Galilean Arabic's it ranges from 30.0 to 46.7 [61]. In Ankara, 
Turkey, it is 1.7 [58] and 47 [60], and 3.42 in Konya, Turkey. Using weighted averages, the incidence of $\mathrm{DDH}$ in IndoMediterraneans is 5.4, 2.4 for those of Indian descent, and 6.2 for those of Arabic descent (Table 2(b), Figure 2(b)).

(v) Indo-Malays. The incidence of DDH in Indo-Malays varies widely (Table 2(c), Figure 2(c)). In Japanese the incidence ranges from 1.8 [87] to 52.9 [85]; for Chinese 0.07 [74] to 4.41 [56]; for Malay 0.71 [54] to 5.38 [56]. The one study of Thai note an incidence of 0.51 [75]. Using weighted averages, the overall incidence of DDH in Indo-Malays is 1.1, 0.1 in Chinese, 1.6 in Malay, and 6.4 in Japanese.

\section{(vi) Caucasians}

(a) Europe. The incidence in Scandinavia ranges from 0.9 to $28[51,64,92,94-102,104-106,160]$. In the United Kingdom, three studies give a low incidence $(0.91$ in Birmingham, England [111], 1.55 in Manchester, England [33], and 1.7 in Northern Ireland [118]); most range from 3-6 [107, 109, 112-115, 161, 162], with the highest incidence of 30.3 in Aberdeen, Scotland [108]. In Spain, the incidence was 9.78 in Córdoba [121] and 43.4 in Madrid [122] (5.09 for complete dislocation). In the Mediterranean Islands, it was 10.6 in Crete [124] and 25.5 in Sicily [125]). The incidence of DDH is higher in Eastern Europe and ranges from 5.2 in Lastovo Island, Croatia [128] to 113 [133] in West Bohemia, Czech Republic. The average weighted incidence of DDH in the Scandinavia is 3.8, 3.6 in the United Kingdom, 25.5 in Spain and the Mediterranean Islands, and 35.8 in Eastern Europe (Table 2(d), Figure 2(e)).

(b) Australia/New Zealand. The incidence is 7.7 in Adelaide [144], 5.5 in South Australia [67], and 6.6 [44] and 10.5 [143] in Western Australia. In New Zealand, it is 2.19 in Southland [147], 2.65 in Canterbury [146], 3.54 in Auckland [145], and 16.0 [32] in New Plymouth. The averaged weighted incidence of Caucasians in Australia/New Zealand is 6.8 .

(c) Americas. There are few incidence studies in the United States due to its highly mobile population. The incidence is 0.7 in Jefferson County, Alabama [51], 0.8 in Portland, Oregon [150], 1.1 in Iowa [163], and 0.7-6.1 in Utah [164]. In Llanquihue, Chile [149], the incidence is 4.6, 2.3 for complete dislocation and 2.2 for dysplasia/subluxation. The incidences for all Caucasians are shown in Figures 2(d) and 2(e).

(vii) Mixed Races. In a study of 432778 infants born in Birmingham, England between 1960-1984 [165], the birth prevalence of DDH was 2.77 when both parents were Caucasian, 1.37 when both were South Asian (from India, Pakistan, Bangladesh), and 0.66 when both were Caribbean (primarily African). These numbers are similar to the average weighted incidences in this study (3.6 for the United Kingdom, 2.4 for Indian, and 0.1 for Africans), the value for Caucasians and South Indians slightly lower than ours, while that for the Africans is slightly higher. These values changed with mixed matings; 2.77 to 0.78 when one parent was Caucasian and one South Indian and 0.66 to 1.28 when one parent was Caucasian and one Caribbean/African. This confirms the differences noted in the United States with genetic mixing in Africans. Other incidence figures for mixed or unknown racial groups are shown in Table 2(b).

\subsubsection{Clinical Neonatal Hip Instability (Table 3)}

Indigenous Peoples. The incidence of neonatal hip instability in the Maori is less than Caucasians [191], where $16 \%$ of the births in one hospital were Maori, but only $7 \%$ of the DDH cases were Maori.

(i) Africans. In Africans, the incidence was 0 in North African Ethiopian Jews [204], 0.3 in South Africa [49], and 2.0 in Uganda [166]. In Oklahoma City it is 0.4 [167] and 0.42 in New York City [168].

(ii) Indo-Mediterraneans. The incidence of neonatal hip instability is 0.17 in Mumbai [205] and 18.7 in New Delhi, India [55], 1.25 in Kuwait (primarily Palestinian) [169], 4.9 in Dammam, Saudi Arabia [170], and 36.5 in Abha, Saudi Arabia [171].

(iii) Amerindians. The incidence of neonatal hip instability in Guanajuato, México is 1.47 [172].

(iv) Indo-Malay. The incidence in Taiwan is 1.2 in Taichung [175] and 1.8 in Taipei [174].

(v) Caucasians. In Europe, the incidence of neonatal hip instability is 4.1 in Uxbridge, England [161], 5.65 in Falköping, Sweden [178], 7.7 in Dublin, Ireland [185], 10.2 in Västerbotten County, Sweden [96], 10.2 in Uppsala, Sweden [180], 12.8 in Cork, Ireland [206], 19 in Bristol, England [187], 20.4 in Uppsala, Sweden [181], 32.2 in Leipzig, Germany [189], 50.0 in Aberdeen, Scotland [188], and 61.7 in Poland [190]. In Australia/New Zealand, it is 3.4 and 8.5 in Auckland, New Zealand [191], 6.6 in Western Australia [192], 6.7 in Sydney, Australia [193], and 19.4 in Victoria, Australia [194]. In North America, it is 1.4 in Iowa City [196], 5.2 in Oklahoma City [167], 8.6 in Salt Lake City [195], 9.2 in Indianapolis, Indiana [198], 5.7 [207] and 9.9 in Vancouver, British Columbia [197], and 15.3 in New York City [168]. The average weighted incidence for all Caucasians is 10.8 (6.0 in Australia/New Zealand to 23.2 in Western Europe).

\subsubsection{Ultrasonographic and Clinical Screening Period (1980s} to Present) (Table 4). For this paper, sonographic DDH is defined as a hip > Graf IIa. North African Black infants (Ethiopian Jews) have a sonographic incidence of 12.4 at birth and 1.5 at 4 to 6 weeks [157]. In Africans living in London, the incidence of sonographic DDH was 0 (0 of 185) [208]. Caucasian infants demonstrate a sonographic incidence at birth from 7.6 [64] to 847 [216], with a weighted average of 131 . At 4 to 6 weeks of age, this drops to $12.8-14.8$, with a weighted average of 14.1. In Turkey, the incidence of sonographic DDH at 6 weeks is 47.1 [60].

Composite results (Table 4 ) denote an average incidence of ultrasonographic DDH in Caucasians at birth of 80.0 (7.6 to 847 ) and 42.2 (3.8 to 103 ) for hips > Graf IIa (range). 
TABLE 3: Incidence of neonatal hip instability by screening physical examination.

\begin{tabular}{|c|c|c|c|c|c|}
\hline Study & Year & Location & No. Pts & No. DDH & $\begin{array}{l}\text { Incidence } \\
\text { (per 1000) }\end{array}$ \\
\hline \multicolumn{6}{|l|}{ Africans } \\
\hline $\begin{array}{l}\text { Robinson and Buse } \\
\text { [166] }\end{array}$ & 1979 & Kampala, Uganda & 2000 & 4 & 2.0 \\
\hline Gross et al. [167] & 1982 & $\begin{array}{l}\text { Oklahoma City, } \\
\text { Oklahoma }\end{array}$ & 2686 & 1 & 0.4 \\
\hline Artz et al. [168] & 1975 & New York City & 4286 & 18 & 0.42 \\
\hline \multicolumn{6}{|l|}{ Indo-Mediterranean } \\
\hline $\begin{array}{l}\text { Abdel-Kader and } \\
\text { Booz [169] }\end{array}$ & 1968 & Kuwait & 4000 & 5 & 1.25 \\
\hline Al-Umran et al. [170] & 1988 & $\begin{array}{l}\text { Dammam, Saudi } \\
\text { Arabia }\end{array}$ & 12733 & 62 & 4.9 \\
\hline $\begin{array}{l}\text { Khan and Benjamin } \\
{[171]}\end{array}$ & 1992 & Abha, Saudi Arabia & 2222 & 81 & 36.5 \\
\hline \multicolumn{6}{|l|}{ Amerindian } \\
\hline $\begin{array}{l}\text { Hernández-Arriaga et } \\
\text { al. [172] }\end{array}$ & 1991 & Guanajuato, México & 16987 & 25 & 1.47 \\
\hline \multicolumn{6}{|l|}{ Indo-Malay } \\
\hline Morito [173] & 1983 & Okayama, Japan & $4824^{*}$ & $51^{*}$ & 10.6 \\
\hline Chen [174] & 1967 & Taipei, Taiwan & 2257 & 4 & 1.8 \\
\hline Hsieh et al. [175] & 2000 & Taichung, Taiwan & 3345 & 4 & 1.2 \\
\hline \multicolumn{6}{|l|}{$\begin{array}{l}\text { Caucasians- } \\
\text { Scandinavia }\end{array}$} \\
\hline Andrén [176] & 1962 & Malmö, Sweden & 28292 & 64 & 2.26 \\
\hline von Rosen [177] & 1970 & Malmö, Sweden & 34520 & 171 & 4.94 \\
\hline Palmén [178] & 1961 & Falköping, Sweden & 12394 & 70 & 5.65 \\
\hline $\begin{array}{l}\text { Hinderaker et al. } \\
\text { [179] }\end{array}$ & 1994 & All Norway & 959412 & 9483 & 9.88 \\
\hline Beckman et al. [96] & $1970-73$ & $\begin{array}{l}\text { Västerbotten County, } \\
\text { Sweden }\end{array}$ & 11613 & 119 & 10.2 \\
\hline $\begin{array}{l}\text { Almby and Rehnberg } \\
\text { [180] }\end{array}$ & 1977 & Uppsala, Sweden & 29339 & 298 & 10.2 \\
\hline $\begin{array}{l}\text { Hiertonn and James } \\
\text { [181] }\end{array}$ & 1968 & Uppsala, Sweden & 11868 & 242 & 20.4 \\
\hline Medbö [182] & 1961 & Ålesund, Norway & 3242 & 50 & 15.4 \\
\hline Cyvín [183] & 1977 & Trondheim, Norway & 6509 & 146 & 22.4 \\
\hline \multicolumn{6}{|l|}{$\begin{array}{l}\text { Caucasians_Western } \\
\text { Europe }\end{array}$} \\
\hline \multirow{2}{*}{ Dickson [184] } & \multirow{2}{*}{1912} & Paris, France & 1502 & 12 & 8.0 \\
\hline & & Rennes, France & 220 & 9 & 41.0 \\
\hline Jones [113] & 1977 & Norwich, England & 29366 & 76 & 2.58 \\
\hline Finlay et al. [161] & 1967 & Uxbridge, England & 14594 & 60 & 4.1 \\
\hline $\begin{array}{l}\text { O'Brien and McGill } \\
\text { [185] }\end{array}$ & 1970 & Dublin, Ireland & 10081 & 77 & 7.6 \\
\hline Barlow [33] & 1962 & Salford, England & 9289 & 139 & 14.9 \\
\hline Wilkinson [112] & 1972 & $\begin{array}{l}\text { Southampton, } \\
\text { England }\end{array}$ & 6272 & 37 & 5.9 \\
\hline Galasko et al. [186] & 1980 & Salford, England & 11980 & 179 & 14.9 \\
\hline Dunn et al. [187] & 1985 & Bristol, England & 23002 & 445 & 19.3 \\
\hline
\end{tabular}


Table 3: Continued.

\begin{tabular}{|c|c|c|c|c|c|}
\hline Study & Year & Location & No. Pts & No. DDH & $\begin{array}{l}\text { Incidence } \\
\text { (per 1000) }\end{array}$ \\
\hline Lennox et al. [188] & 1993 & Aberdeen, Scotland & 67093 & 3354 & 50.0 \\
\hline Mitchell [107] & 1972 & Edinburgh, Scotland & 31961 & 226 & 7.1 \\
\hline \multirow[t]{4}{*}{ Drescher [189] } & 1957 & Leipzig, Germany & & & \\
\hline & & All & 5098 & 164 & 32.2 \\
\hline & & Vertex & 4953 & 104 & 30.0 \\
\hline & & Breech & 145 & 19 & 131 \\
\hline \multicolumn{6}{|l|}{$\begin{array}{l}\text { Caucasians-Eastern } \\
\text { Europe }\end{array}$} \\
\hline Szulc [190] & $1961-66$ & Poland & 2608 & 161 & 61.7 \\
\hline \multicolumn{6}{|l|}{$\begin{array}{l}\text { Caucasians- } \\
\text { Australia and New } \\
\text { Zealand }\end{array}$} \\
\hline Phillips [191] & 1968 & $\begin{array}{l}\text { Auckland, New } \\
\text { Zealand }\end{array}$ & 43025 & 148 & 3.4 \\
\hline Bower et al. [192] & 1989 & Western Australia & 67757 & 450 & 6.6 \\
\hline $\begin{array}{l}\text { Chaitow and } \\
\text { Lillystone [193] }\end{array}$ & 1984 & Sydney, Australia & 450 & 3 & 6.7 \\
\hline Goss [194] & 2002 & Victoria, Australia & 5166 & 100 & 19.4 \\
\hline \multicolumn{6}{|l|}{$\begin{array}{l}\text { Caucasians-North } \\
\text { America }\end{array}$} \\
\hline Coleman [195] & 1956 & Salt Lake City, Utah & 3500 & 30 & 8.6 \\
\hline Ponseti [196] & 1978 & Iowa City, Iowa & 51359 & 72 & 1.4 \\
\hline Gross et al. [167] & 1982 & $\begin{array}{l}\text { Oklahoma City, } \\
\text { Oklahoma }\end{array}$ & 7490 & 39 & 5.2 \\
\hline $\begin{array}{l}\text { Lehmann and Street } \\
{[148]}\end{array}$ & 1981 & $\begin{array}{l}\text { Vancouver, British } \\
\text { Columbia, Canada }\end{array}$ & 23234 & 132 & $5.7^{*}$ \\
\hline $\begin{array}{l}\text { Tredwell and Bell } \\
\text { [197] }\end{array}$ & 1981 & $\begin{array}{l}\text { Vancouver, British } \\
\text { Columbia, Canada }\end{array}$ & 32480 & 321 & 9.9 \\
\hline Ritter [198] & 1973 & Indianapolis, Indiana & 3278 & 30 & 9.2 \\
\hline \multirow[t]{3}{*}{ Artz et al. [168] } & 1975 & New York, New York & 19020 & 291 & 15.3 \\
\hline & & All & 1528069 & 16452 & 10.8 \\
\hline & & Scandinavia & 1085576 & 10524 & 9.7 \\
\hline \multirow[t]{3}{*}{$\begin{array}{l}\text { Caucasian's weighted } \\
\text { avg. }\end{array}$} & & $\begin{array}{l}\text { Australia/New } \\
\text { Zealand }\end{array}$ & 116398 & 701 & 6.0 \\
\hline & & Western Europe & 185734 & 4312 & 23.2 \\
\hline & & North America & 140361 & 915 & 6.5 \\
\hline \multicolumn{6}{|l|}{$\begin{array}{l}\text { Mixed/Unknown-All } \\
\text { Geographic Locations }\end{array}$} \\
\hline Ein [199] & 1957 & Newark, New Jersey & 4597 & 7 & 1.5 \\
\hline Stanisavljevic [200] & 1962 & Detroit, Michigan & 5125 & 35 & 6.8 \\
\hline $\begin{array}{l}\text { Weissman and Salama } \\
\text { [201] }\end{array}$ & 1969 & Tel Aviv, Israel & 6841 & 45 & 2.7 \\
\hline \multirow[t]{4}{*}{ Klingberg et al. [202] } & 1976 & Rehovot, Israel & & & \\
\hline & & & 12150 & 172 & 14.2 \\
\hline & & & 6204 & 49 & 7.9 \\
\hline & & & 5946 & 123 & 20.7 \\
\hline Khrouf et al. [203] & 1986 & Tunis, Tunisia & 10000 & 41 & 4.1 \\
\hline
\end{tabular}

\footnotetext{
* The incidence and either the numerator/denominator were given; appropriate values calculated when possible.
} 
TABLE 4: Incidence of DDH in the ultrasound screening period era (1980s-present)*

\begin{tabular}{|c|c|c|c|c|c|c|c|c|c|}
\hline Study & Year & Location & Ethnicity & Time & No. Pts & No. DDH & Incid. & $>$ Graf IIa & $\begin{array}{c}\text { Incid. > Graf } \\
\text { IIa }\end{array}$ \\
\hline \multicolumn{10}{|l|}{$\begin{array}{l}\text { At } \\
\text { birth-2 } \\
\text { weeks }\end{array}$} \\
\hline $\begin{array}{l}\text { Eidelman } \\
\text { et al. [157] }\end{array}$ & 2002 & Ethiopia & Black Jews & Birth & 768 & 19 & 24.7 & 10 & 13.0 \\
\hline $\begin{array}{l}\text { Poul et al. } \\
\text { [208] }\end{array}$ & 1998 & $\begin{array}{l}\text { London, } \\
\text { England }\end{array}$ & Black & Birth & 185 & 0 & 0.0 & 0 & 0.0 \\
\hline $\begin{array}{l}\text { Chang et } \\
\text { al. [73] }\end{array}$ & 2007 & Taiwan & $\begin{array}{l}\text { Indo-Malay } \\
\text { (Chinese) }\end{array}$ & & & & & & \\
\hline $\begin{array}{l}\text { Danielsson } \\
{[64]}\end{array}$ & 2000 & $\begin{array}{l}\text { Malmö, } \\
\text { Sweden }\end{array}$ & $\begin{array}{c}\text { Indo-Med. } \\
\text { (Iraqi/Iranian) }\end{array}$ & & 1604 & 7 & 4.4 & & \\
\hline $\begin{array}{l}\text { Danielsson } \\
{[64]}\end{array}$ & 2000 & $\begin{array}{l}\text { Malmö, } \\
\text { Sweden }\end{array}$ & Caucasian & Birth & 15189 & 115 & 7.6 & & \\
\hline $\begin{array}{l}\text { Treiber et } \\
\text { al. [209] }\end{array}$ & 2008 & $\begin{array}{l}\text { Maribor, } \\
\text { Slovenia }\end{array}$ & Caucasian & Birth & 17393 & 324 & 18.6 & 369 & 21.2 \\
\hline $\begin{array}{l}\text { Vencálková } \\
\text { and Janata } \\
{[136]}\end{array}$ & 2009 & $\begin{array}{l}\text { Liberec, } \\
\text { Czech } \\
\text { Republic }\end{array}$ & Caucasian & Birth & 16678 & & & 212 & 12.7 \\
\hline $\begin{array}{l}\text { Rosendahl } \\
\text { et al. [210] }\end{array}$ & 1996 & $\begin{array}{l}\text { Bergen, } \\
\text { Norway }\end{array}$ & Caucasian & Birth & 3613 & 1613 & 446.4 & 123 & 34.0 \\
\hline $\begin{array}{l}\text { Bache et } \\
\text { al. [211] }\end{array}$ & 2002 & $\begin{array}{l}\text { Coventry, } \\
\text { England }\end{array}$ & Caucasian & Birth & 29323 & 3866 & 131.8 & 2340 & 79.8 \\
\hline $\begin{array}{l}\text { Szöke et al. } \\
{[212]}\end{array}$ & 1988 & $\begin{array}{l}\text { Cologne, } \\
\text { Germany }\end{array}$ & Caucasian & Birth & 1000 & 524 & 524.0 & 40 & 40.0 \\
\hline $\begin{array}{l}\text { Tönnis et } \\
\text { al. [213] }\end{array}$ & 1990 & $\begin{array}{c}\text { Dortmund, } \\
\text { Germany }\end{array}$ & Caucasian & Birth & 2587 & 1877 & 725.6 & 137 & 53.0 \\
\hline $\begin{array}{l}\text { Rühmann } \\
\text { et al. [214] }\end{array}$ & 1998 & $\begin{array}{l}\text { Hanover, } \\
\text { Germany }\end{array}$ & Caucasian & Birth & 6617 & 436 & 65.9 & 217 & 32.8 \\
\hline $\begin{array}{l}\text { Parten- } \\
\text { heimer et } \\
\text { al. [215] }\end{array}$ & 2006 & $\begin{array}{c}\text { Greifswald, } \\
\text { Germany }\end{array}$ & Caucasian & 4-10 days & 2256 & & & 110 & 48.8 \\
\hline $\begin{array}{l}\text { Exner } \\
{[216]}\end{array}$ & 1988 & $\begin{array}{c}\text { Zurich, } \\
\text { Switzerland }\end{array}$ & Caucasian & Birth & 615 & 521 & 847.2 & 28 & 45.5 \\
\hline $\begin{array}{l}\text { Peled et al. } \\
\text { [217] }\end{array}$ & 2008 & Haifa, Israel & Caucasian & Birth & 45497 & & & 2137 & 47.0 \\
\hline $\begin{array}{l}\text { Giannako- } \\
\text { poulou et } \\
\text { al. [124] }\end{array}$ & 2002 & Crete & Caucasian & 2 wks & 6140 & 65 & 10.6 & 50 & 8.1 \\
\hline $\begin{array}{l}\text { Ballerini et } \\
\text { al. [218] }\end{array}$ & 1990 & Milan, Italy & Caucasian & Birth & 2842 & 778 & 273.8 & 57 & 20.1 \\
\hline $\begin{array}{l}\text { Riboni et } \\
\text { al. [219] }\end{array}$ & 1991 & Milan, Italy & Caucasian & Birth & 1507 & 508 & 337.1 & 15 & 10.0 \\
\hline $\begin{array}{l}\text { Franchin } \\
\text { et al. [220] }\end{array}$ & 1992 & Bari, Italy & Caucasian & Birth & 3000 & 959 & 319.7 & 309 & 103.0 \\
\hline $\begin{array}{l}\text { Baronciani } \\
\text { et al. [20] }\end{array}$ & 1997 & Lecco, Italy & Caucasian & Birth & 4648 & 1186 & 255.2 & 267 & 57.4 \\
\hline $\begin{array}{l}\text { Riboni et } \\
\text { al. [221] }\end{array}$ & 2003 & Milan, Italy & Caucasian & Birth & 8896 & 2008 & 225.7 & 34 & 3.8 \\
\hline $\begin{array}{l}\text { Yiv et al. } \\
\text { [143] }\end{array}$ & 1997 & $\begin{array}{c}\text { South } \\
\text { Australia }\end{array}$ & Caucasian & & 19622 & 206 & 10.5 & & \\
\hline $\begin{array}{l}\text { Weighted } \\
\text { average } \\
\text { (Cau- } \\
\text { casians) }\end{array}$ & & & & & 187423 & 14986 & 80.0 & 6445 & 42.2 \\
\hline
\end{tabular}


TABle 4: Continued.

\begin{tabular}{|c|c|c|c|c|c|c|c|c|c|}
\hline Study & Year & Location & Ethnicity & Time & No. Pts & No. DDH & Incid. & $>$ Graf IIa & $\begin{array}{c}\text { Incid. > Graf } \\
\text { IIa }\end{array}$ \\
\hline \multicolumn{10}{|l|}{$\begin{array}{l}\text { At } 4 \text { to } 6 \\
\text { weeks }\end{array}$} \\
\hline $\begin{array}{l}\text { Eidelman } \\
\text { et al. [157] }\end{array}$ & 2002 & Ethiopia & Black Jews & 6 wks & 768 & 3 & 3.9 & 3 & 3.9 \\
\hline $\begin{array}{l}\text { Doğruel et } \\
\text { al. [60] }\end{array}$ & 2008 & $\begin{array}{l}\text { Ankara, } \\
\text { Turkey }\end{array}$ & $\begin{array}{l}\text { Indo-Med } \\
\text { (Turkish) }\end{array}$ & 6 wks & 3541 & 167 & 47.2 & 208 & 58.7 \\
\hline $\begin{array}{l}\text { Bache et } \\
\text { al. [211] }\end{array}$ & 2002 & $\begin{array}{l}\text { Coventry, } \\
\text { England }\end{array}$ & Caucasian & 6 wks & 29323 & 92 & 3.1 & & \\
\hline $\begin{array}{l}\text { Roovers et } \\
\text { al. [222] }\end{array}$ & 2005 & $\begin{array}{l}\text { Enschede, } \\
\text { Netherlands }\end{array}$ & Caucasian & 4 wks & 4473 & 1697 & 379.4 & 132 & 29.5 \\
\hline $\begin{array}{l}\text { Weighted } \\
\text { average } \\
\text { (Cau- } \\
\text { casians) }\end{array}$ & & & & & 33796 & 1789 & 52.9 & 132 & 29.5 \\
\hline \multicolumn{10}{|l|}{$\begin{array}{l}\text { At } 4 \text { to } 6 \\
\text { Months }\end{array}$} \\
\hline $\begin{array}{l}\text { Krolo et al. } \\
{[129]}\end{array}$ & 1989-2001 & $\begin{array}{l}\text { Zagreb, } \\
\text { Croatia }\end{array}$ & Caucasian & 4 months & 2010 & 120 & 59.7 & 15 & 7.5 \\
\hline $\begin{array}{l}\text { Akman et } \\
\text { al. [223] }\end{array}$ & 2007 & $\begin{array}{l}\text { Ankara, } \\
\text { Turkey }\end{array}$ & & 6 months & 403 & & & 14 & 34.7 \\
\hline
\end{tabular}

* The data for the last two columns those having > Graf IIa instability are for all hips, while the previous columns are for children.

At 4 to 6 weeks of age, these numbers drop to 52.9 (range 3.1379.4) and to 29.5 for hips $>$ Graf IIa, and by 4 to 6 months of age to 7.5-34.7 for DDH > Graf IIa. This incidence of 7.5-34.7 is similar to that for Caucasians during the clinical screening period from 1950-1980 (3.8 in Scandinavia, 5.5 in Western Europe, 6.8 in Australia/New Zealand, and 35.8 in Eastern Europe) (Table 2).

3.3. Gender, Laterality, Family History, Perinatal Factors (Table 5). Typical risk factors for $\mathrm{DDH}$ are said to be female, first born, breech position, positive family history, left hip, and unilateral involvement. In 9717 cases (Table 5), $75.5 \%$ were female and $63.4 \%$ unilateral. When unilateral, $36.0 \%$ involved the right and $64.0 \%$ the left hip. Leftsided predominance of DDH may reflect the finding that right-sided laterality in birth defects correlates with the proportion of males among a group of infants with any given pathology [232]. There is minimal gender variability by ethnicity (Figure 3(a)) but considerable variability in bilaterality (Figure 3(b)), ranging from 16.7\% in Indo-Malay to $69 \%$ in South American Caucasians. Although the left hip is typically more involved in those with unilateral dysplasia, there is significant ethnic variability, 44\% in IndoMediterraneans to $81.4 \%$ in Caucasians from Australia/New Zealand (Figure 3(c)). The prevalence of mild adult acetabular dysplasia in children with documented unilateral DDH is up to $40 \%$ [233].

Breech position/presentation increases the incidence of DDH $[32,34,44,54,56,63,65,67,100-102,105,106,114$, $118,135,139,162,168-171,191,225,226,229-231,234-$ 243]. Breech position/presentation in children with DDH ranges from $7.1 \%$ [32] to $40 \%$ [65]. In Western Australia
[44], the incidence was 27.7 for breech and 5.5 for vertex presentations; in Denmark [106], 18.9 for breech and 5.5 for vertex presentation; in Northern Ireland, 6.94 for breech and 1.55 for vertex presentation [118]. In Singapore, the incidence was 10.7 in breech deliveries, 8.4 in vacuum extraction deliveries, and 0.7 overall [54]. In Norway [100102 ], $15.7 \%$ of DDH children were breech compared to $3.4 \%$ in the normal population; in Helsinki, Finland, these numbers were $19.0 \%$ and $3.5 \%$ [105]; in Hungary, $11.4 \%$ and $3.1 \%$ [142]. In Riyadh, Saudia Arabia, these same numbers were $38 \%$ and $8.8 \%$ [226]; in Kuwait, $7 \%$ and $3.7 \%$. In two Finnish hospitals, DDH was present in 2.6 and $6.6 \%$ of children with breech presentation [240], 7.7\% in Stockport, England [229], 18\% in Scotland [162], and $25 \%$ in London [235]. In Southampton, England, 36\% of complete dislocations and $83 \%$ of subluxations were breech [112]. In certain Native Americans, there is no correlation with breech presentation/delivery [37, 44].

Breech presentation/presentation also influences neonatal hip instability. In 6571 live births (257 breech) [244], the odds ratio (OR) of hip instability was 3.42 in all breech babies and 11.1 for those with DDH needing treatment. The incidence of clinical hip instability in breech babies is 44 in Norway [179] (61 specifically in Trondheim, Norway [245]), 71 in New York City [168], 107 in Thailand [236], 131 in Leipzig, Germany [189], and 260 in Malmö, Sweden [176]. In Leipzig [189], the incidence of neonatal hip instability was 131 in breech and 30 in vertex presentations; in Tiachung, Taiwan, these numbers were 8.9 breech and 0.6 vertex [175]. In Dammam, Saudi Arabia [170], breech presentation was present in $13 \%$ of newborns with neonatal hip instability and $2.1 \%$ without. In Trondheim, Norway, the incidence of 


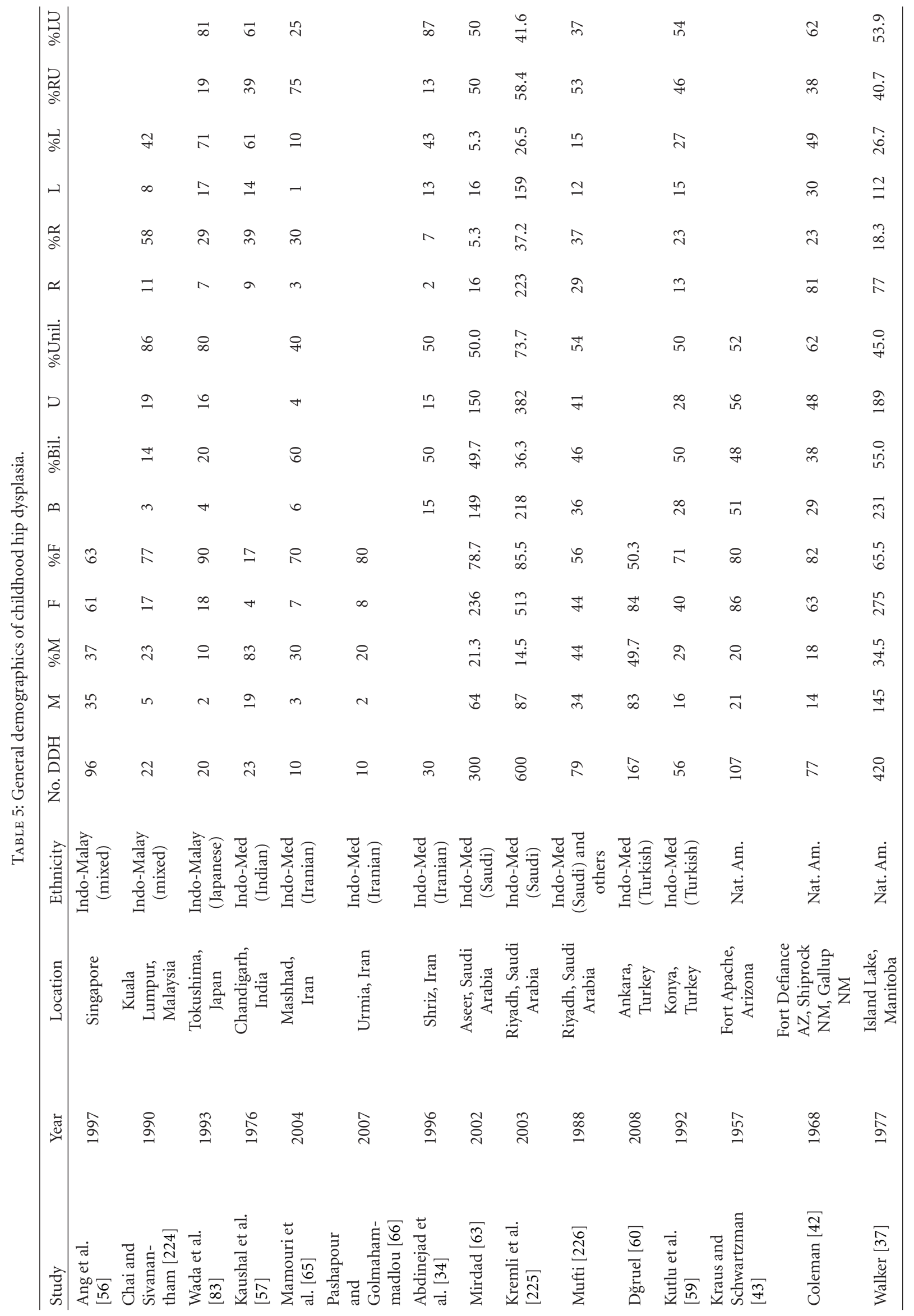




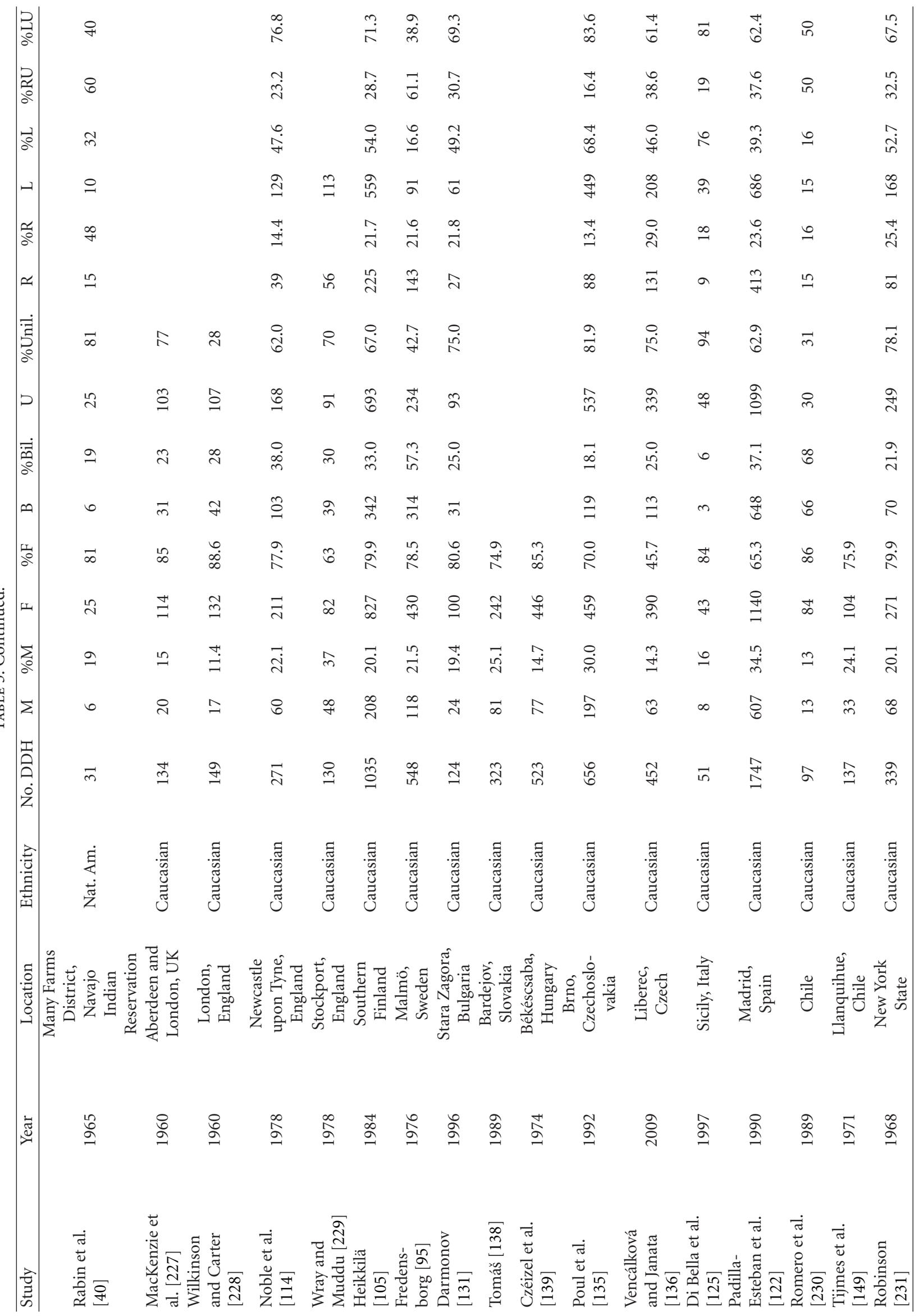




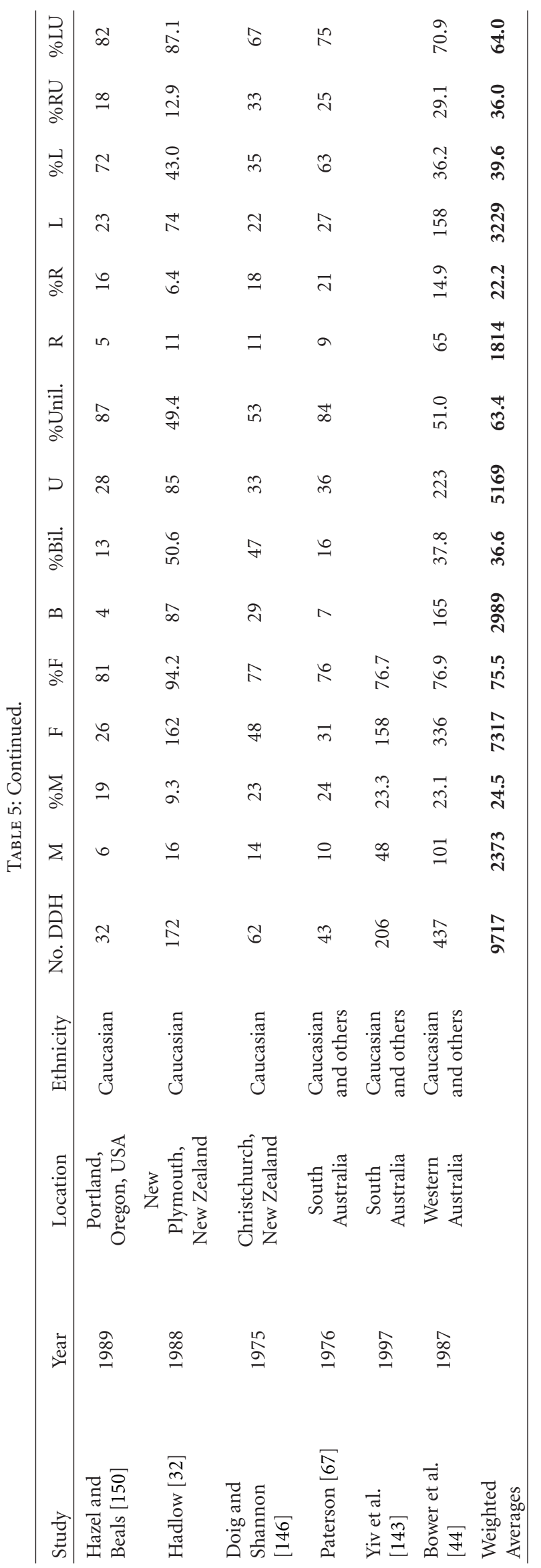


DDH-gender by ethnicity

Caucasian

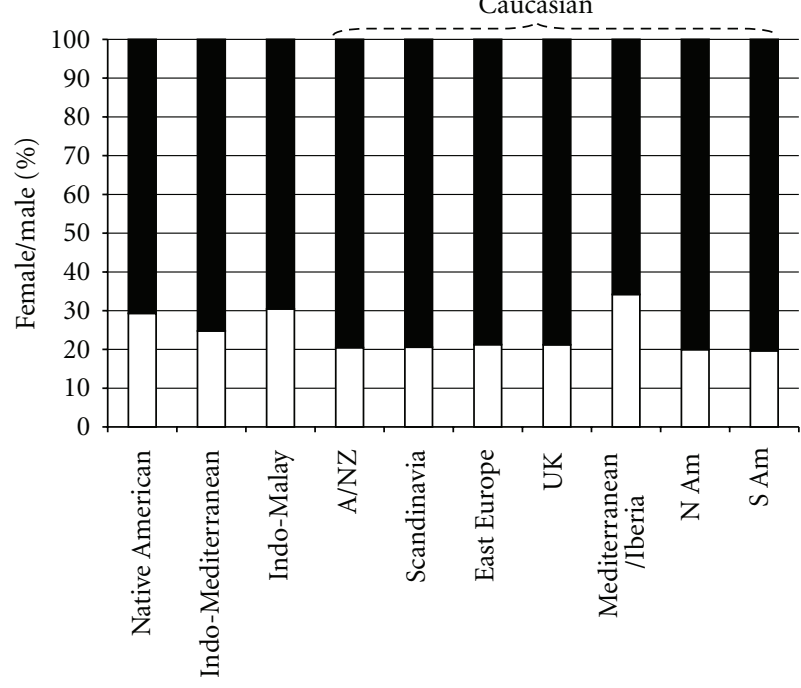

Ethnic group

Female

$\square$ Male

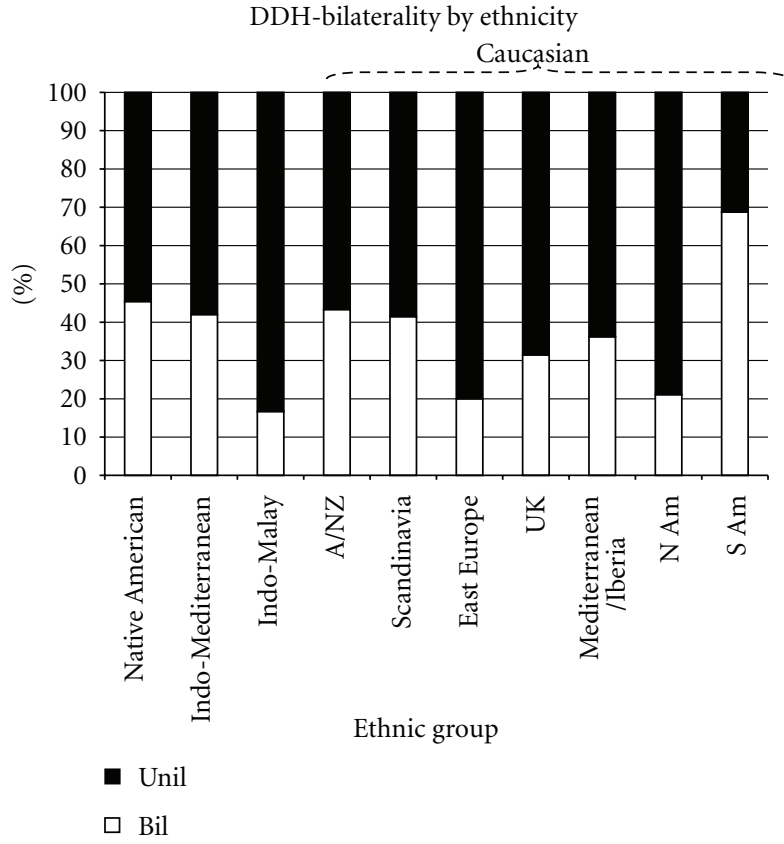

(b)

DDH-right versus left by ethnicity

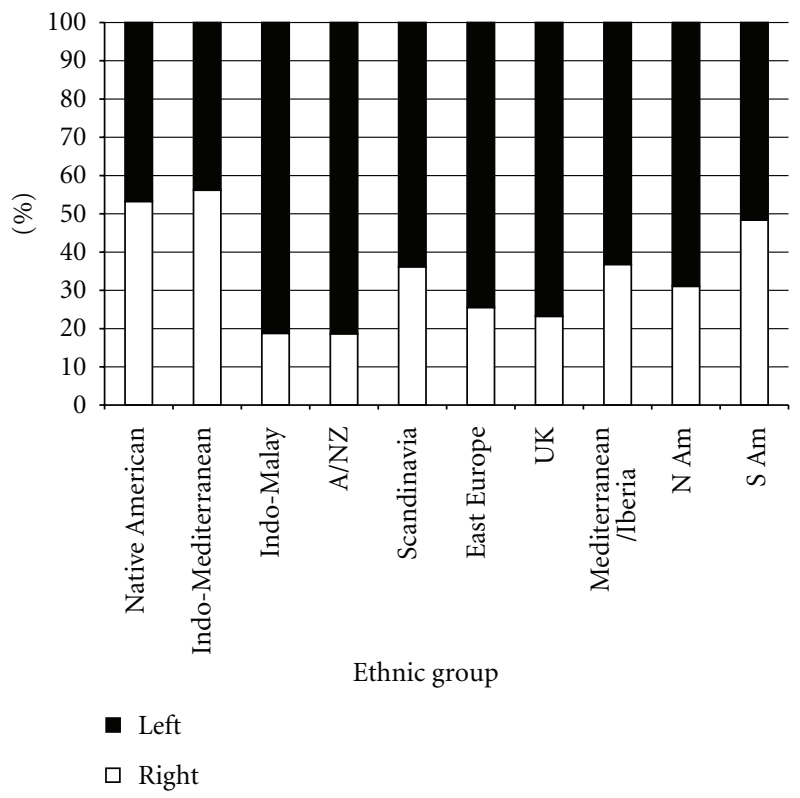

(c)

FIGURE 3: Variability in DDH demographics amongst ethnic groups. (a) Variability in gender amongst ethnic groups. (b) Variability in unilateral/bilateral involvement amongst ethnic groups. (c) Variability in right and left hip involvement amongst ethnic groups.

ultrasonographic hip instability in breech presentation is 61 [245]. In Germany, the incidence of ultrasonographic ( $>$ Graf IIa) neonatal hip instability in 3739 newborns was 136 in 317 breech children and 64 in nonbreech children [242]. In another German study; however, there was no correlation between intrauterine presentation and sonographic hip instability [215].

Breech-type (frank breech or bilateral hip flexion/knee extension, nonfrank, or varying amounts of hip and knee flexion) is also important. The incidence of DDH in 
Hungarian breech children was 340 in nonfrank and 185 in frank breech [241]. In Norway [245], the incidence of DDH in frank breech was higher than other breech types. DDH in breech children may be decreased by elective Caesarean section [246]; of 941 breech presenting infants, the incidence of DDH was 3.69\% (19 of 515) when delivered by elective pre-labor Caesarean section, 6.64\% (26 of 241) when delivered by intrapartum Caesarean section, and $8.11 \%$ (15 of 185) when delivered vaginally. In New York, children born by Caesarean section had a 3.4 times higher chance of DDH when breech compared to vertex presentation, and those born vaginally had a 7.0 times higher chance of $\mathrm{DDH}$ when breech compared to vertex presentation [168].

The incidence of DDH is less in premature and lowbirth-weight infants [44]. Children $<37$ wk gestational age had an incidence of $3.4,37-42$ wks 6.3 , and $>42$ wks 29.9; for those $<2500 \mathrm{gms}$, the incidence was 4.1, 2500-3499 gms 6.7, and $>3500$ gms 6.4. In another study, all babies with DDH had a gestational age of 39 weeks or more, and $52 \%$ were firstborn [234]. In Northern Ireland, the risk of DDH was less when the birth weight was $<3.0 \mathrm{~kg}$ [118]. Children born large for gestational age (LGA) have an increased risk of hip subluxation (OR 1.73) [247] and twice the incidence of ultrasonographic DDH ( $\geq$ Graf IIc) compared to normalbirth-weight newborns (6.1\% versus 3.5\%) [248]. In breech presentation, DDH is more common in those with higher birth weights $(3.49 \mathrm{~kg}$ with $\mathrm{DDH}, 3.06 \mathrm{~kg}$ without $\mathrm{DDH}$ ) [245]. Very-low-birth-weight infants are not at increased risk of DDH [249].

Primiparity increases the risk of DDH. In Hungary [142], the average birth order of 1767 children with DDH was 1.37 compared to 1.54 for 108966 control children showing that DDH children are skewed to the first born. In Finland, 63\% of DDH children were first born compared to $55 \%$ in the normal population [105], in Southampton, England, 83\% of children with subluxation were first born [112], and in Madrid, Spain, 50\% of were firstborn [122]. In Western Australia [44], the incidence was 7.6 if first born and 5.9 if multiparous. At Christchurch Women's Hospital, first-borns accounted for $83 \%$ of DDH children but only $42 \%$ of all births [146]. In Utah, USA, the primiparity was $46 \%$ greater than expected in the 327 cases of DDH. In Singapore [56], $43.8 \%$ to $50 \%$ of DDH children were firstborn [54].

A positive family history increases the risk of $\mathrm{DDH}$ $[38,42,60,63,65,105,162,225,230,250-253]$; it was $14 \%$ in Poland [253], 21\% in Saudia Arabia [63], and 35\% in Greece [124]. In Native Americans, it was 33\% in the Navajo [42]. In northern Saskatchewan Cree, it was 16\% in sisters and $14 \%$ in mothers [38] but no correlation in the Manitoba Cree-Ojibwa [37]. In 589 English children with DDH, $4.01 \%$ of 1 st degree and $0.33 \%$ of 2 nd and $3 \mathrm{rd}$ degree relatives had DDH [162]. In 1256 Japanese children with $\mathrm{DDH}, 6.1 \%$ of siblings, $0.7 \%$ of parents, and $0.5 \%$ of uncles/aunts had DDH [252]. In 500 Utah children with DDH, 24.5\% of 1st degree relatives had DDH [164]. In two Hungarian families with DDH, DDH occurred in $14 \%$ of family members: siblings, $2.1-2.3 \%$, parents, $1.2-$ $1.4 \%$ of uncles/aunts, and $4.7 \%$ of cousins [254]; recurrence risks were 8 , and $4 \mathrm{x}$ increased in brothers and sisters, $4 \mathrm{x}$ in parents, $2.5 \mathrm{x}$ in uncles/aunts, and $2.0-2.5 \mathrm{x}$ in cousins compared to the general population. The risk or liability of inheriting DDH amongst siblings was $49 \%$ in Turkey [255]; the overall heritability was $74 \%$ in Norway [101]. An association between DDH and familial primary acetabular dysplasia [256] also exists; radiographs of the mothers of DDH children who did not have any known preexisting DDH demonstrated acetabular dysplasia in 8.65\% [252]. One negative study exists regarding the association between ultrasonographic DDH and family history [215].

Consanguinity results in a very high incidence of $\mathrm{DDH}$ in Japan [81] and the Middle East where 25\% [169], 40\% [65], and $49 \%$ [225] of DDH cases were from consanguineous parents. In western Galilee, an area with a high incidence of $\mathrm{DDH}$, marriage between 1st cousins is frequent $[61,257]$. Tight gene pools were implicated in the high incidence of DDH in Fort Apache Navajos [43].

To simplify these figures, epidemiologists use decision analysis/meta-analysis or multiple logistic regression to determine DDH risk factors. The clinical practice guidelines of the American Academy of Pediatrics [5] used a decision analysis model, concluding that the baseline incidence of $\mathrm{DDH}$ (not at risk children) was 11.5 (4.1 for boys and 19 for girls). The relative risk with a positive family history is 1.7 times higher (for an absolute incidence of 6.4 for boys and 32 for girls), and the relative risk for a breech presentation compared to vertex is 6.3 times higher (for an incidence of 29 for boys and 133 for girls).

Logistic regression analysis of 1127 South Australian DDH children (1986-1993) [7] demonstrated that breech presentation, oligohydramnios, female gender, and primiparity were significant positive risk factors for DDH; low birth weight and prematurity were protective. The ORs were 17.2 for breech deliveries, 10.0 for breech presentation with Caesarean delivery, 4.0 for oligohydramnios, 3.9 for female gender, 2.7 for very high birth weight ( $>4500 \mathrm{gm}), 2.2$ for first born, and older maternal age (1.71 for 30-34 years old and 1.72 for $\geq 35+$ years old). Protective ORs were low birth weight ( 0.3 for $<2000$ gm, 0.52 for $2000-2499$ gms) and prematurity $(0.42$ for $<37$ wks gestation, 0.59 for $37 \mathrm{wks}$ gestation, and 0.80 for 38 wks gestation).

In 51 Israeli DDH children (1994-1995), ORs were 6.0 for breech presentation, 4.3 for female gender, and 2.7 for primiparity [258]. In 81 Nottingham children with DDH and 323 control subjects [259], the ORs for those born by Caesarean section or breech delivery were 3.29 and 4.57, respectively, and 0.55 and 0.53 for multigravida and multiparity; maternal age, gestational age, placental weight, race/ethnicity, and birth weight/height were not risk factors [259].

In $1,059,479$ Norwegian children [179], predictors of neonatal hip instability (clinical exam) were gestational age, gender, and breech presentation; birth order had no effect. The overall incidence of neonatal hip instability overall was 10.3 with differences by birth weight (2.6$<2500$ gms; $10.2-\geq 2500 \mathrm{gms}$ ) and presentation (9.3 vaginal vertex, 10.1 Cesarean section vertex, 45.4 vaginal breech, 42.5 Cesarean breech). With increasing gestational, the incidence of neonatal hip instability increased for each category of 
gender and presentation (female vertex, female breech, male vertex, male breech).

\subsection{Twin Studies and Genetics}

3.4.1. Twin Studies. In 589 children with DDH, there were five pairs of twins (1.7\%): two monozygotic and three dizygotic [162]. The frequency of concordance (both twins having the same pathology) was $\sim 33 \%$ in monozygotic twins and $\sim 8 \%$ in dizygotic twins [260] supporting a polygenic mechanism. Even with this high of a concordance rate, the majority of monozygotic twins are not concordant, demonstrating that the same genetic background and intrauterine environment does not result in DDH most of the time [260]. The Norwegian Twin Registry found an incidence of 4.3 DDH in twins (38 of 8794). The OR of DDH in a relative of an effected twin was $10.0: 35.8$ for mothers, 12.7 for siblings, 8.1 for fathers, and 3.3 for subsequent offspring [261]. The increased OR for mothers over fathers suggests a maternal effect. In 4678 opposite sex twins, the relative risk of $\mathrm{DDH}$ was 0.13 for males compared to females [262]. Mirroring has been described in two sets of identical twins $[263,264]$ with $\mathrm{DDH}$; one twin had left DDH and the other right DDH. Both sets also had mirrored strabismus, and thumb sucking was mirrored in one set [263].

3.4.2. Genetic Patterns. The prevalence of DDH in France in 1912 was 8 in Paris and 36-41 in Rennes, (Brittany region) $[12,184]$ with an epicenter in Pont l'Abbé. DDH did not occur in this geographic area in the 1700s, and it appeared that a genetic mutation occurred in the 19th century [184]. The genetic mechanism was postulated to be autosomal dominant with incomplete penetrance and penetrance dependent upon gender [12]. In 16 Turkish family members with $\mathrm{DDH}$, an autosomal dominant inheritance was also noted [265].

Most other investigators propose a two-gene system in DDH. In 589 children with DDH [162], one gene involved joint laxity (dominant) and the other acetabular dysplasia (polygenic). The risk of subsequent members of a family having DDH when one family member had DDH was 36\% when there was one affected parent and child, $12 \%$ when there was one affected parent and no affected children, and $6 \%$ when both parents were normal and had one affected child with DDH [266]. A Hungarian study [267] confirmed the role of polygenic acetabular morphometry and monogenic joint laxity; neonatal and "late-diagnosis" cases did not seem to be different entities. In an Italian study of pedigrees from 171 patients with familial DDH [268] (1937 individuals in 507 nuclear families with 499 having $\mathrm{DDH})$, segregation analysis demonstrated that a two-locus recessive-recessive model was the most appropriate fit. The major locus demonstrated a penetrance of $5.9 \%$ in males and $58.6 \%$ in females, and the modifier locus $0.3 \%$ in males and $15.6 \%$ in females.

Homozygous recessive conditions (attached earlobes, light eyes, color blindness, inability to roll the tongue, and 3 wrist creases) are increased in children with DDH [269]; $5.2 \pm 0.1$ in controls and 7.1 \pm 0.2 in DDH.
3.4.3. HLA and ABO Blood Type Groups. In Greek children with DDH [270] there was a significant increase in HLA $A_{1}$ in the DDH group (52 versus $26 \%$ ). In Czechoslovakia, there was a significant decrease in the HLA $B_{7}$ type in the DDH group (10\% versus 26\%) [271]. In Japanese [272] the development of DDH and dysplastic osteoarthritis of the hip is associated with genes in the HLA-D regions, especially HLA DR4. No differences in ABO blood types [168, 259, 269, 273] or Rh blood types [259] have been found in DDH.

3.4.4. Associated Genes and Chromosomal Locations. In Han Chinese, DDH was associated with gene growth differentiate factor 5 (CDF5) (OR 1.40) [274]. The double von Willebrand factor A gene on chromosome 3p24.3 is strongly associated with osteoarthritis of the knee in Japanese and Chinese [275] but not DDH [275]. Estrogen receptor Xba I wild type (XX compared to $\mathrm{Xx}$ and $\mathrm{xx}$ ) is more common in $\mathrm{DDH}$ than controls (55.8\% versus 37.9\%) [276]. Homozygosity for the mutant Taq1 vitamin D receptor $t$ allele is associated with an increased acetabular index, and the Pvu II pp estrogen receptor genotype is associated with a low center-edge angle [276].

Several studies associate DDH with chromosome 17q21. This region contains a cluster of HOX genes that provide specific positional identities to mesenchymal cells in developing joints [277]. In French Caucasians, there was no increased association between DDH and the HOXB9 gene [270] while in the Chinese there is an association with the HOXB9 as well as the COL1A1 genes in DDH [278]. In Italian Caucasians, the COLL2A1 and vitamin D receptor genes are associated with nonsyndromic DDH [279] but not confirmed by others [280]. In an 18 member multigenerational family affected by $\mathrm{DDH}, \mathrm{a} 4 \mathrm{Mb}$ region on chromosome $17 \mathrm{q} 21.32$ was linked to DDH [277].

3.5. Ligamentous Laxity. Joint laxity is increased in $\mathrm{DDH}$ $[235,266,267,281-283]: 75 \%$ of boys and $33 \%$ of girls with DDH demonstrate joint laxity [235]. The prevalence of joint laxity ( $\geq 3$ joints) in normal children ages $6-11$ years was $10.5 \%$ and $47 \%$ in DDH children [282]. Increased joint laxity likely explains the increase in inguinal hernias in $\mathrm{DDH}$ children and their fathers and brothers [142, 266, 283]. Girls with DDH have a 5-fold increase and boys with DDH a 3fold increase in inguinal hernias; the hernia also develops earlier in life than normal [284]. Relaxin, which stimulates collagenase, alters the connective tissue and may lead to the development of both DDH and inguinal hernias.

Collagen metabolism is altered in DDH. In newborns with $\mathrm{DDH}$, the amount of umbilical cord collagen was decreased ( 26\%) [285] but not total protein [286]; this was not found in another study [173]. Umbilical cord type III/I collagen ratio is increased in DDH [286]. Hip capsule and skin biopsies in older DDH children (1 to 4 years old) show a decreased type III/I collagen ratio in the hip capsule but not the skin [287]. Opposite results were found in Japanese children with DDH [288] where the type III/I collagen ratio was increased in the hip capsule and ligamentum teres. The ligamentum teres in DDH children demonstrates thicker collagen fiber bundles and increased hyalinization in those with complete dislocation compared to subluxation [289]. 
In patients with hypermobility syndrome (including several cases of DDH) [290], growth hormone, insulin, and IGF-1 levels were elevated, leading us to endocrine abnormalities in $\mathrm{DDH}$.

3.6. Hormonal/Endocrine and Metabolic Associations. DDH occurs predominantly in females, and a hormonal/endocrine relationship has long been suspected. In newborns with $\mathrm{DDH}$, there is an increase in urinary excretion of conjugated estrogen and $17 \beta$-estradiol [291-293], suggesting that DDH may be due to abnormal estrogen metabolism. Abnormal fetoplacental estrogen metabolism in a mother and child with DDH has been described [294].

Others found no estrogen metabolism abnormalities. Urinary estrogen excretion in the first 3 days of life in 7 newborns with bilateral Ortolani instability and 4 normal newborns was not different [295]. Urinary excretion of oestradiol, oestrone, and oestriol in 16 neonatal hip instability, and 19-matched-control newborns [296] showed no differences. Similar conclusions were reached by Borglin [297]. Umbilical cord blood measurements of $17 \beta$-estradiol levels in 2185 consecutive newborns [298] with neonatal hip instability showed conflicting data; in boys low levels $(<10 \mathrm{nmol} / \mathrm{L})$ increased the risk of neonatal hip instability (OR 54) while in girls high levels ( $>15 \mathrm{nmol} / \mathrm{L}$ ) increased the risk (OR 2.2).

Women who develop pelvic joint instability and pain in pregnancy have an increased risk of a child with DDH [299]: incidence of 7-9 compared to the normal 2-3. In another study of Norwegian women with pregnancy-initiated pelvic pain, the incidence of DDH in the children was 45 [300], 7 times normal [179]. Women with pelvic joint instability and pain have higher serum relaxin levels compared to those without pelvic pain [301] in the third trimester which may explain these associations; others refute this [302, 303]. There is no correlation between serum relaxin in umbilical cord blood and neonatal hip instability [304, 305].

In adults previously treated for DDH without surgery, bone mineral density at the hip but not the spine is decreased with a concomitant increase in osteocalcin [306]. The OR of decreased bone mineral density at the hip was 6.3 for those with DDH. Some children with DDH demonstrate lower serum calcium and alkaline phosphatase but not serum phosphorus [307].

3.7. Seasonal Variation. Most studies note an increase in the number of DDH births in the winter. In Tokyo, 549 of $1276(43 \%)$ DDH children were born on NovemberJanuary [308]; in Kochi, Japan, 55 of 106 (52\%) were born on December-February [81]. Other Japanese studies confirm this winter predominance $[83,90,309]$, likely due to the increase of extension diapering/swaddling in the colder months. In Navajo boys, a slight increase was noted in the midwinter [37] but no seasonal variation was noted in other Navajos [40].

In Caucasians many studies also note a predominance of DDH births in the fall/winter months: September-December in Scandinavia [97-102]; September-November throughout Sweden [176, 310]; October-January in Israel [70]; Novem- ber in Alicante, Spain [243]; September-January [311] and November-March in Leipzig [312]; December-February in Berlin [313], Northern Ireland [118], and Scotland [162]; December in all of the United States [231]; SeptemberFebruary in Utah [164]; September-March in England [110, 314, 315]; December-January in Debrecen, Hungary [141]; October-February in Budapest, Hungary [142]; NovemberFebruary in Dêčín and Česká Lípa, Czechoslovakia [134]; December-March in Tel Aviv, Israel [201, 316]; and JanuaryApril in East Anglia, England [317]. In the southern hemisphere, the same was also noted: July-August in Southland, New Zealand [147], and in Australia, April-June in Victoria [318], June in Adelaide, and July in Brisbane [319]. Infants born in colder winter months demonstrate poorer acetabular development compared to those born in the warmer months [320] as measured by acetabular depth and acetabular angles; this may explain the increase in DDH in children born in the winter or may represent an effect of increased swaddling or tight clothing to protect the baby from the colder weather. Pelvic insufficiency also shows a seasonal variation [321] with a peak in November-December.

Bimodal peaks were seen in Bardejov, Slovakia (July and February) [138]. Peaks were noted in the spring in Córdoba, Spain [121]; in the summer in Southampton, England [112], Helsinki, Finland [105], and Israel [202].

No seasonal variation was noted in Atlanta [322], Manchester and Newcastle-upon-Tyne, England [33, 114], Liberec, Czech Republic [136], Western Australia [44], Auckland, New Zealand [191], Christchurch and North Canterbury, New Zealand [146], and New York City [168].

3.8. Swaddling. Swaddling theoretically maintains the hip in an extended and adducted position; radiographs of hips in cradled infants demonstrate that they are not in true adduction, and up to $15-20^{\circ}$ of abduction is possible [40]. Newborn swaddling used in many cultures [323] is considered by many to be a significant factor in the development of DDH. In 2300 Navajos [40], hip dislocation was more prevalent in adults than children. It was postulated that this decrease in dislocation was due to the transition from exclusive use of the Navajo cradleboard to a more frequent use of diapers.

Swaddling/cradle boards in a few studies are not associated with DDH. In the Navajo, 9 of 13 cases of DDH which spontaneously improved showed improvement while on the cradleboard, and 2 cases with complete dislocation were never kept on the cradleboard [40]. Nearly all the CreeOjibwa swaddle their children (tihkinākan cradleboard) [38], yet in 427 untreated Cree-Ojibwa infants with hip dysplasia, frank improvement was seen in 113 with $\geq 1$ year of followup. Most interestingly, 21 of the 113 had an initial diagnosis of complete dislocation [37]. Swaddling is also used in Saudia Arabia (mehad) [326] and Iran (ghondagh) [34] with no differences in the use of mehad/ghondagh for those with or without DDH. These studies question the role of swaddling.

Most other studies demonstrate a strong correlation between swaddling and DDH. There was a 10-fold increase in DDH (123.0 versus 12.6) in Canadian Native Americans 
from Ontario who used the cradleboard [39]. Similar concerns were noted in the Cree from northern Quebec [327]. In Turkey [59], 98\% of DDH cases were swaddled as infants compared to $87.1 \%$ not swaddled; the $\mathrm{OR}$ of $\mathrm{DDH}$ in swaddled children was 6.1 [223]. In a sonographic Turkish study [60], swaddling was used in $21.2 \%$ of those children with $\mathrm{DDH} \geq$ Graf IIb $(P<0.001)$, which was the highest risk factor associated with $\mathrm{DDH}$, greater than breech delivery $(9.0 \%)$, positive family history $(6.6 \%)$, and female gender $(6.2 \%)$. The incidence of ultrasonographic dysplasia in children at high risk for DDH in Qatar [328] dropped from 20\% to $6 \%$ after a community awareness program demonstrating the harmful effects of swaddling and discouraging its use; swaddling alone did not cause the hip dysplasia but had an unfavorable effect on the future course of a dysplastic hip. Another study from Saudi Arabia concluded that swaddling was an important factor in the etiology of DDH [329]. Swaddling is also believed to be responsible for the high incidence of DDH in the Arabic peoples in Western Galilee [61] and Iraqi immigrants in Israel [330].

In Europe, Békés County, Hungary [139], swaddling was believed to account for the high incidence (28.7) of DDH and supported by others [134]. In the Swedish Sámi, the cradleboard (gietka or komse) was also believed to account for the high incidence (24.6) of DDH [46]. The gietka is a cradle hollowed from a log tightly swaddling the lower extremities and allowing for minimal movement. This cradle was very practical in the Sámi nomadic culture and lifestyle and allowed mothers to carry the cradle across their shoulders onto a reindeer's pack saddle; as their nomadic reindeer herding culture and lifestyle decreases and health nurses forbid the use of the geitka/komse [324, 331], the prevalence of DDH in the Sámi has fallen (Figure 4(a)).

DDH is very rare in cultures where swaddling is not used (Southern Chinese, African Bantu, Thailand, North Korea, Sri Lanka [332]); the absence of swaddling is believed to be responsible for this [333]. Two different northern circumpolar peoples (Sámi and Inuit/Eskimos) have markedly different incidences of DDH $[324,334]$; the Sámi, who swaddled their young in the past, had a very high incidence, while the Inuit/Eskimo's, whose mothers carried their young inside their parkas in a hood (amauti) abducting the hips around their backs have an incidence of DDH similar to Caucasians.

In Japan, swaddling/diapering in extension was strongly associated with DDH [85]. This is especially so for children born in the winter months, being more tightly wrapped to protect against the cold [335]. This effect of swaddling/ diapering with the hips in extension was initially noted in a small series of 5 normal newborn children; no hip instability was noted within the 1st 24 hours on physical examination, but after diapering in extension, 4 of 5 children developed Ortolani-positive hip instability [84]. This resulted in a larger study, and the creation of an educational campaign regarding the problems associated with extension diapering/swaddling in Kyoto, Japan [85]. The incidence of DDH dropped from 52.9 in 1971-97 to 5.6 in 1974-1976 after the educational campaign [85]. These results in Kyoto led to a national Japanese education and prevention campaign [335] with similarly striking results (Table 2(c), Figure 4(b)). This demonstrates the impact of epidemiological/demographic studies in reducing the occurrence of a particular condition.

Swaddling thus influences the development of DDH $[336,337]$. This is particularly relevant since there is a strong resurgence to return to swaddling to reduce crying and promote uninterrupted sleep in the baby [336, 338, 339]. Swaddled infants arouse less and sleep longer; preterm infants show improved neuromuscular development, selfregulatory ability, and less physiologic distress when swaddled [338]. Infants that are at an increased risk of DDH should probably not be swaddled unless imaging studies are absolutely normal [336]; appropriate swaddling also must be used [340].

3.9. "Late Diagnosis" of DDH. When the hip actually dislocates [341-343] has been debated for some time [344]. The studies of "late" diagnosis reveal several findings. In one study, all the children were female, and $40 \%$ (8 of 20) had recognized risk factors [345]. Canadian children [346] diagnosed with DDH at an older age (20 months) have more right hip involvement ( $31 \%$ versus $15 \%$ right hips) compared to those diagnosed younger ( $<20$ months) who have more left hip involvement (57\% versus 15\% left hips); bilateral dislocations are also more common when diagnosed at an older age (44 versus 28\%) [346]. In Norway the incidence of "late" diagnosis was 2.4; of these 197 Norwegian children diagnosed "late" [347], all hips were stable at birth; 86\% were female, the left hip was involved in $48 \%$, right hip in $31 \%$, and both in $21 \%$. Breech delivery occurred in only $6.5 \%$. The incidence of late DDH in all of Norway was 2.4 [347]: 1.7 in Oslo and 0.76 in southern Finland [348]. In Glasgow it was 0.84 before and 0.57 after institution of a selective ultrasound screening program [349]. A positive family history was associated with an increased risk of "late" DDH [350]. Avascular necrosis of the opposite normal hip in children with "late" diagnosis was described (9 of 103 cases) and associated with high, free-riding dislocations [351].

\subsection{Miscellaneous Demographic and Epidemiologic Findings}

\subsubsection{In Utero Environment}

Exposures to Agents. Administration of progesterone in the 1st trimester for threatened or habitual abortion [352] increases the risk of DDH as does maternal hypothyroidism [353] and maternal phenylketonuria [354]. Maternal smoking during pregnancy reduces the risk of sonographic DDH $\geq$ Graf IIa in female but not male neonates [355], most likely due to the effects of maternal smoke on estrogen physiology. The incidence of DDH in children whose mothers were exposed to radiation at Hiroshima or Nagasaki, Japan $(0.31$ and 0.23 ) is higher than those not exposed to radiation in Kure, Japan (0.13) [356]. In Seveso, Italy, no increase in $\mathrm{DDH}$ was seen after exposure of a densely populated area to TCDD (2,3,7,8-tetracholorobenzo-p-dioxin) [357]. Intrauterine toxoplasmosis [358] or viral infection [132] does not increase the risk of DDH. Iron deficiency anemia in fetal life may been associated with DDH [359]. 


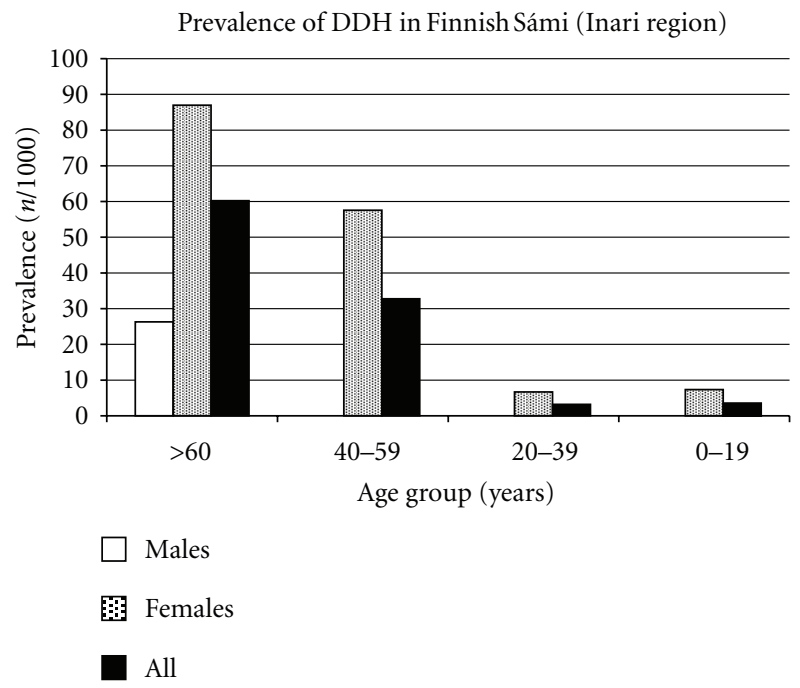

(a)

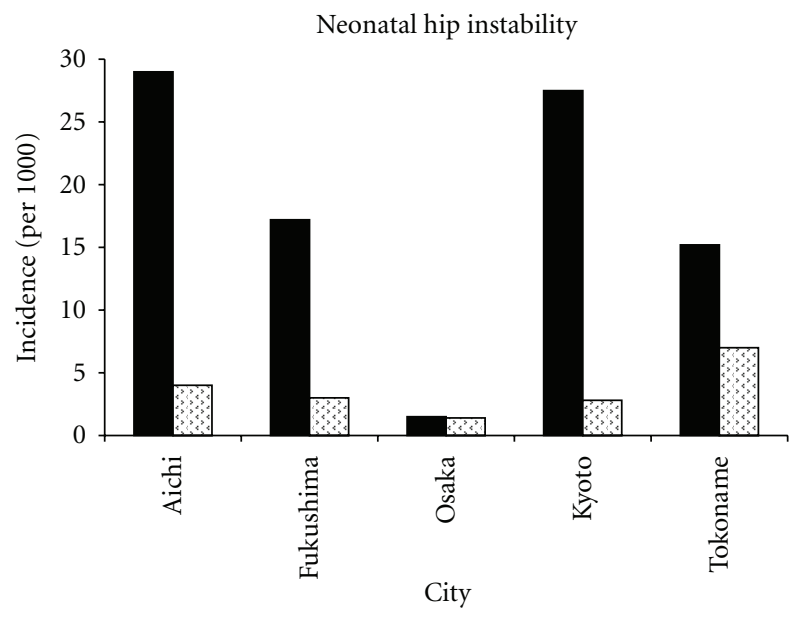

Before

○ After

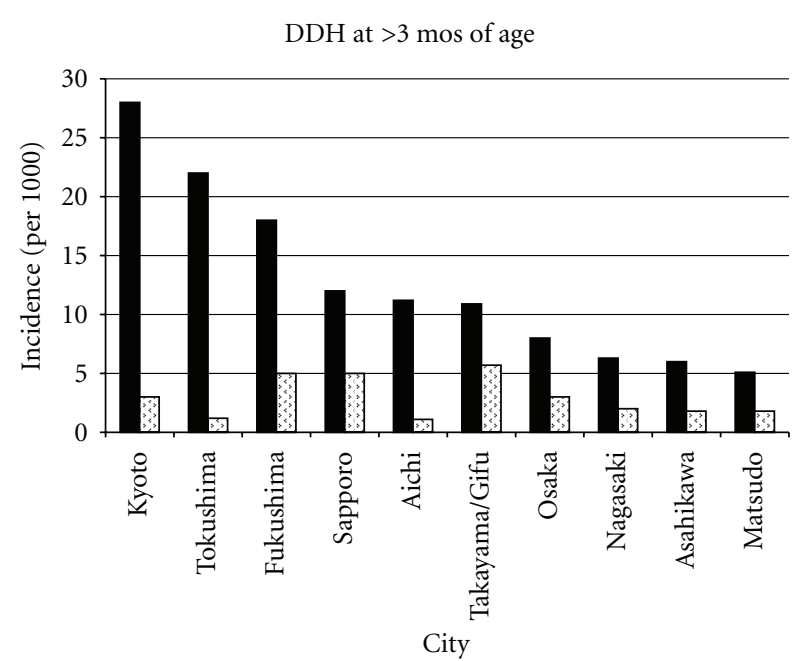

Before

After

(b1)

(b)

FIgURE 4: (a) The prevalence of DDH in the late 1970's by age group in the Sámi living in northern Finland, Lake Inari region. The overall prevalence was 16.3; for those $\geq 60$ years of age it was 60.2, and dropped to 3.5 for those $0-19$ years of age. This has been attributed to a decrease in the practice of newborn swaddling using the gietka or komse. Data from Eriksson et al. [324]. (b) The marked decrease in DDH incidence in Japan after introduction of a nationwide educational program for both neonatal hip instability and hip dislocation after 3 months of age. For neonatal hip instability the data was taken from $[84,325]$ and for hip dislocation from [83-90].

Mechanical and/or Physical Exposures. Multifetal pregnancies (e.g., twins, triplets) are not at increased risk of DDH $[142,360-368]$. There were no cases of DDH in 968 sets of twins and 18 sets of triplets in Tokyo [369]. Two studies noted less DDH in children born to multifetal pregnancies (relative risk 0.57 [370], 0.46 [371]). Although extrauterine pregnancy is rare ( 1 in 1100 to 1 in 50000 pregnancies) [372], it is often associated with DDH $[373,374]$, suggesting DDH is associated with molding forces in those circumstances rather than a teratological abnormality [372].

Mid-trimester amniocentesis does not increase the risk of DDH [375] whereas 1st trimester likely does [376] (OR 1.22). Premature labor and/or threatened abortion increases the risk of DDH $[132,377]$. Prior miscarriage increases the risk of a subsequent child having DDH (OR 1.4) [378]. Preterm infants demonstrate a decrease in neonatal hip instability on 
physical examination compared to term infants [379] and do not demonstrate an increase in $\geq$ Graf IIb DDH even though many are immature (Graf IIa) [380]. Preterm infants demonstrate no increase in $\mathrm{DDH}$ even after reaching normal development and gestational age [381].

3.10.2. Parental Associations. DDH was more common in higher socioeconomic groups in Scotland [162] but more common in lower groups in Martin, Slovakia [137]; no differences in New York City [168] or England [110] were noted by socioeconomic class. Paternal plywood mill workers had an increased risk (OR 2.71) of DDH in 14415 British Columbian children [399].

Older paternal age has been associated with DDH [400]. Younger maternal age is a function of birth order and primiparity [164]. In one study, DDH and maternal age demonstrated a bell-shaped curve with a peak at 30 years of age [401]. Short maternal stature is associated with DDH in Canada [402] and Ireland [403] but not in Britain [403]. Early abduction treatment in children with neonatal instability is associated with increased maternal anxiety, while the use of ultrasound to manage infants with $\mathrm{DDH}$ is not [404].

3.10.3. Child Development. The median walking age in 86 DDH children diagnosed at an average age of 16 months was not statistically different from a control group of 100 normal children with fractures (13.8 months-DDH; 12.5 monthscontrol) [405]. Menarche in girls with DDH was decreased by 6 months compared to others [406]. DDH children have lower skin temperature on the affected lower limb [407].

\subsection{Associated Conditions}

3.11.1. Congenital Muscular Torticollis. DDH is associated with congenital muscular torticollis (CMT) [433-441]. The proportion of DDH in CMT children is $2.4 \%$ [441], 3.7\% [434], 4.1\% [437], 4.5\% [440], 8\% [435], 12\% [438], 13\% [439], 14.1\% [442], 17\% [443], and 20\% [433]. Boys are particularly at risk [434]. CMT also has a higher incidence of breech presentation (19.5\%) [437]. DDH risk is directly related to the severity of CMT [441]. The incidence of DDH in Hong Kong children with CMT is 48.1 compared to 0.1 in the general population [74].

3.11.2. Congenital Foot Deformity. There is some association between DDH and metatarsus adductus [444-446]; the proportion of DDH in children with metatarsus adductus is $1.53 \%$ [444] and $10 \%$ [445]. The proportion of $\mathrm{DDH}$ children with congenital clubfoot is $0.3 \%$ ( 1 of 349) [447], $1 \%$ (16 of 1509) [446], and 5.9\% (9 of 119) [448]. There is a slight association between positional clubfeet and DDH [447]. Acetabular dysplasia (acetabular index $>28^{\circ}$ at $\geq 4$ months of age) occurred in $16 \%$ of children with congenital clubfoot [449]. Sonographic Graf type IV (irreducible DDH) occurred in $6.5 \%$ of children with congenital vertical talus and $4 \%$ with metatarsus adductus [450].

3.11.3. Spinal and Neuromuscular Associations. Abnormal sensory evoked potentials in DDH children 10-13 months of age were present in $31 \%$ without spinal dysraphism and $56 \%$ with spina bifida occulta [451]. The incidence of $\mathrm{DDH}$ is 10 times greater in children with infantile scoliosis [452]. One study found no free nerve endings in either the ligamentum teres or hip capsule of DDH children [453] while the ligamentum teres had a higher frequency (66.6\%) of type IVa free nerve endings [289] in DDH children, suggesting a role of abnormal nocioception/proprioception [454]. Vibration arthrometry demonstrates low-frequency vibrations in unstable (Ortolani- or Barlow-positive) neonatal hips $[455,456]$.

Electrophysiological and histological examinations of the hip muscles in DDH demonstrate muscle degeneration which is more severe in younger children [457]; the iliopsoas, gluteus medius, and vastus lateralis muscles demonstrated hyaline granulous degenerative changes [458]. Others note minimal histological changes [459].

3.11.4. The Opposite Hip in Unilateral DDH. The opposite hip in "unilateral DDH" children often develops abnormally: $14 \%$ [460], 31\% [461], 34\% [462], and 43\% [233]. The center-edge angle is the most predictive single measurement of delayed acetabular development while the overall best predictor is the hip ratio (CE angle +100 (acetabular depth/acetabular diameter))/2 [461]. A low ratio indicates a more abnormal hip; $<22$ is abnormal for those $<2$ years old and $<23$ for those $\geq 2$ years old. This makes it possible to predict if the opposite hip is "at risk" [461]. Contralateral abduction hip contracture occurs in children with unilateral $\mathrm{DDH}[463,464]$ as well as diffuse pelvic asymmetry if diagnosed after 4 months of age [465].

3.12. Transition from Childhood to Adult Hip Dysplasia. Persistent childhood dysplasia [466] and neonatal hip instability predisposes to adult hip disease. The Norwegian Medical Birth Registry was correlated with the Arthroplasty Registry [467]; when adjusting for gender and year of birth, there was a 2.6 times increased risk (95\% CI 30-105) for children with neonatal hip instability to undergo total hip replacement. Of the 442 patients undergoing hip replacement, 95 had the surgery due to degenerative joint disease from residual hip dysplasia, yet only 8 had neonatal hip instability. This underscores the need for continued vigilance in the screening of neonatal hip instability and long-term followup. It also confirms that there is a significant amount of hip dysplasia, with no physical findings in childhood, that later becomes symptomatic in adult life (e.g., asymptomatic radiographic dysplasia). Underlying joint laxity may also predispose to the development of adult hip osteoarthritis $[468,469]$.

3.13. Adult Hip Dysplasia. The incidence and demographics/epidemiology of adult hip dysplasia is easier to study yet there are fewer and less detailed studies. The diagnosis of dysplasia, aside from complete dislocation, involves relatively simple radiographic measurements [470]. The center-edge (CE) angle of Wiberg is most commonly used to determine hip dysplasia [398] but only quantifies lateral coverage, ignoring other methods such as anterior coverage assessment with the false-profile radiograph [470]. The literature 
defining acetabular dysplasia is confusing; some studies use a CE angle $<20^{\circ}$, while others use $22.5^{\circ}, 25^{\circ}$, and $30^{\circ}$ as the cutoff (Table 6). Also, intra- and interobserver agreement in $\mathrm{CE}$ angle measurement is $\sim \pm 3 \%$ [471]. Considering these caveats, the prevalence of acetabular dysplasia ranges from $5.9 \%$ in Caucasians to $\sim 19 \%$ in the Sámi.

Adult hip osteoarthritis (OA) is either primary or secondary. Primary OA is a diagnosis of exclusion and defined as when neither an anatomic abnormality nor any specific disease is identified as the cause [475]. Secondary OA is due to preexisting conditions, such as DDH, Perthes', and SCFE. Hoaglund [475] noted that normal hip anatomy was present in $>80 \%$ of degenerative hip arthritis patients and that an underlying defect in articular cartilage or bone leads to the eventual development of OA in most Caucasians.

For the other $20 \%$, what relations exist between mild dysplasia, ethnicity, and hip OA? The magnitude of adult acetabular dysplasia does not always correlate with degenerative hip disease in adults [385-387, 474, 475]. We must first know the prevalence of hip OA, and there are two ways to determine this number. One is the radiographic prevalence of hip OA. When using this method, the prevalence of radiographic hip OA is greater in men than in women and greater in Caucasians, intermediate in Blacks, and rare in Indo-Malays [472] (Figure 5(a)). The second is to determine total hip replacement rates, since truly symptomatic hip OA will likely come to THR. THR rates in San Francisco [473], in a population-based study, showed significant variation by ethnicity (Figure 5(b)), with Caucasians having a rate of THR $\sim 10$ times that of Indo-Malay peoples (Chinese, Japanese, Filipino), $\sim 1.5$ to 2 times that of Blacks, and $\sim 3$ to 4 times that of Hispanics.

Variations in the frequency of hip OA are not necessarily caused by differences in the occurrence of hip dysplasia. There are marked differences in the etiology of hip osteoarthritis between Japanese Indo-Malays and American Caucasians [474]. In patients with osteoarthritis of the hip, secondary osteoarthritis was present in $\sim 82 \%$ of the Japanese patients but only $10.1 \%$ of Caucasian Americans (Figure 5(c)). There is more acetabular dysplasia in Japanese adults but more hip OA in British Caucasians [385]. The prevalence of acetabular dysplasia (defined as a $\mathrm{CE}<25^{\circ}$ ) was $0.5 \%$ in British Caucasians and $17.3 \%$ in Japanese, yet the prevalence of hip OA was lower in Japan (0\% men, $2 \%$ women) compared to Britain ( $11 \%$ men, $4.8 \%$ women). In a random effects' statistical model, a negative relationship was actually discovered between acetabular dysplasia and joint space [385]; as acetabular depth increased (CE angle), joint space decreased. This was confirmed in Hong Kong where there is a lower prevalence of radiographic OA in Hong Kong men compared to British men, yet acetabular dysplasia was equal in prevalence in both groups [391]. It was also confirmed in France with a negative correlation between acetabular dysplasia and the risk of hip OA [390]. The highest prevalence of OA was in French men (5.8\%) who had a low prevalence of hip dysplasia (1.8\%), while the highest prevalence of acetabular dysplasia was in Japanese women (11.6\%) who had a low prevalence of OA (3.5\%). In Turkish adults [395] there is no direct correlation between acetabular dysplasia and hip OA. The prevalence of acetabular dysplasia is similar between British Caucasian men and Nigerian Black men, yet the prevalence of hip OA was less in the Nigerian men [382]. In the Sámi, there is no evidence that acetabular dysplasia is associated with OA [476].

In other populations; however, there is a definite correlation between acetabular dysplasia/residual childhood DDH and secondary hip OA [474, 477]. This is especially true in Asian populations [478], where the development of $\mathrm{OA}$ is nearly guaranteed if there is preexisting acetabular dysplasia or subluxation. In Japan, $97 \%$ of hip OA cases were secondary, with $88 \%$ due to $\mathrm{DDH}$ [479]. In elderly United States Caucasian women, mild acetabular dysplasia is associated with an increased risk of hip osteoarthritis [388]. The exceedingly low prevalence of acetabular dysplasia in Saudi people has been suggested as a contributing factor to their very low prevalence of OA [394].

\subsection{Both Child and Adult Hip Dysplasia-Archeological} Evidence. There has been significant interest in hip dysplasia and archeological remains (Table 7). A systematic review in this domain is quite difficult due to the many detailed, but hard to identify and access, theses and monographs. Thus, the papers discussed here are not included in the 422 of 2277 manuscripts reviewed. We attempted to review the literature as best as possible, well recognizing that some studies have been missed. Many archeological studies are not applicable being solely a case description of a skeleton with DDH with no data from which a prevalence can be calculated. In archeological studies, prevalence rather than incidence is calculated. As DDH begins some time in infancy, and since there were no diagnostic/treatment methods for children with DDH in the eras of these archeological studies, prevalence and incidence become identical. With anthropological materials, the exact diagnosis may be questioned due to many different types of hip dislocation. However, a critical review was performed, and all attempts were made to exclude posttraumatic, neuromuscular, or infectious dislocations.

3.14.1. Europeans. In 700 skeletons buried in six medieval (4th to 13th century) sites from Northern and Eastern France [408], six had DDH. In 900 skeletons from the NotreDame-du-Borg cathedral gravesite (8th to 17 th century) in Southern France (Digne) [409], nine had DDH. In the Spitalfields cemetery in London, used between 1150 and $1530 \mathrm{AD}$ [410], 3290 pairs of hips were sufficiently preserved for study; nine had DDH. In 100 skeletons (all affluent citizens) from a Minorite monastery churchyard cemetery in Dordrecht, Netherlands, one had DDH [414]. In 70 skeletons from post-medieval (1550 to 1700) Bobald, Transylvania, Romania [412], two had DDH. In327 skeletons at Devín, Slovakia (9th-12th century AD) [413], DDH was noted in one. In 271 skeletons from the Southern East Siberian area of Cis-Baikal (6800-1000 BC) one had DDH [415].

In the Mediterranean areas, a study of 139 Herculaneum people buried by the Mt. Vesuvius volcano in $79 \mathrm{AD}$ demonstrated one DDH [418]. In Padua, Italy, a study of 213 skeletons (Tedeschi Osteological Collection) from the late 19th and early 20th centuries demonstrated one DDH 


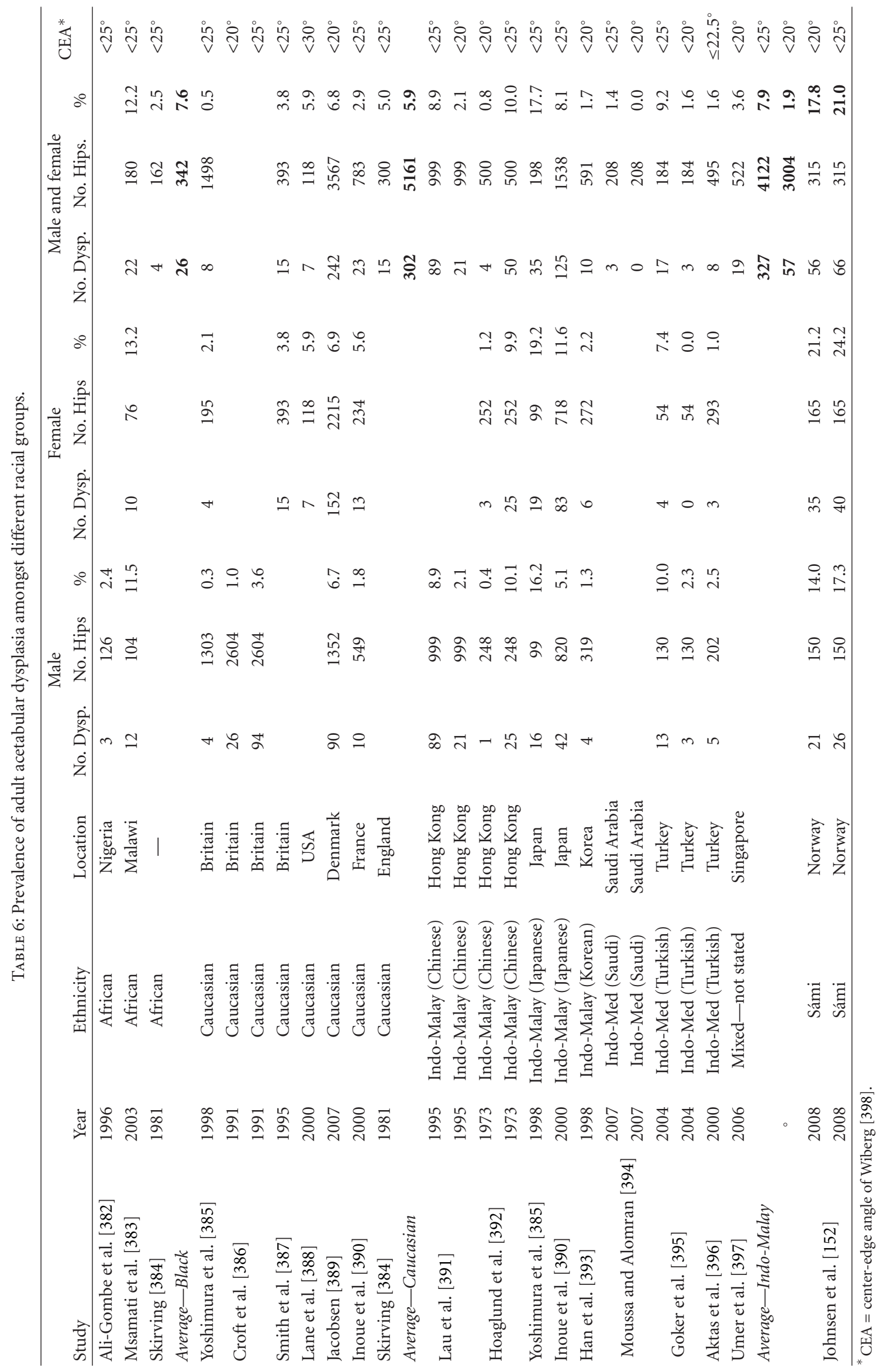


TABle 7: Archeological studies of hip dysplasia.

\begin{tabular}{|c|c|c|c|c|c|c|c|c|c|c|}
\hline Study & Year & $\begin{array}{l}\text { Archeological } \\
\text { location }\end{array}$ & Era & $\mathrm{M}$ & $\mathrm{F}$ & $\mathrm{U}$ & $\mathrm{B}$ & No. DDH & No. Skeletons & Prevalence \\
\hline \multicolumn{11}{|l|}{$\begin{array}{l}\text { European } \\
\text { peoples }\end{array}$} \\
\hline $\begin{array}{l}\text { Blondiaux } \\
\text { and Millot } \\
{[408]}\end{array}$ & 1991 & $\begin{array}{l}\text { North and } \\
\text { Eastern France }\end{array}$ & $\begin{array}{l}4 \text { th-13th } \\
\text { century }\end{array}$ & 3 & 3 & & & 6 & 700 & 8.6 \\
\hline $\begin{array}{l}\text { Mafart et al. } \\
{[409]}\end{array}$ & 2007 & Southern France & $\begin{array}{l}8 \text { th-17th } \\
\text { century }\end{array}$ & 0 & 9 & 5 & 4 & 9 & 900 & 10.0 \\
\hline $\begin{array}{l}\text { Mitchell and } \\
\text { Redfern } \\
{[410]}\end{array}$ & 2007 & $\begin{array}{l}\text { Spitalfields, } \\
\text { London, UK }\end{array}$ & $1100-1530$ & 5 & 4 & 7 & 2 & 9 & 3290 & 2.7 \\
\hline $\begin{array}{l}\text { Hawkes and } \\
\text { Wells [411] }\end{array}$ & 1983 & $\begin{array}{l}\text { Worthy Park, } \\
\text { Hampshire, } \\
\text { South England }\end{array}$ & $\begin{array}{l}\text { 5th-7th } \\
\text { century }\end{array}$ & & & & & 0 & 99 & 0 \\
\hline $\begin{array}{l}\text { Eng et al. } \\
{[412]}\end{array}$ & 2009 & $\begin{array}{l}\text { Transylvania, } \\
\text { Romania }\end{array}$ & $1550-1700$ & 0 & 2 & & & 2 & 70 & 28.6 \\
\hline $\begin{array}{l}\text { Masnicová } \\
\text { and Beňuš } \\
{[413]}\end{array}$ & 2003 & Devín, Slovakia & $\begin{array}{l}\text { 9th-12th } \\
\text { century }\end{array}$ & 1 & & 1 & & 1 & 327 & 3.1 \\
\hline $\begin{array}{l}\text { Maat et al. } \\
{[414]}\end{array}$ & 1995 & $\begin{array}{l}\text { Dordrecht, } \\
\text { Netherlands }\end{array}$ & $1375-1572$ & & & & & 1 & 100 & 10.0 \\
\hline $\begin{array}{l}\text { Lieverse } \\
{[415]}\end{array}$ & 2005 & $\begin{array}{l}\text { Cis-Baikal, } \\
\text { Siberia }\end{array}$ & $\begin{array}{l}6800-1000 \\
\text { BC }\end{array}$ & & 1 & & & 1 & 271 & 3.7 \\
\hline $\begin{array}{l}\text { Bourbou } \\
{[416]}\end{array}$ & 2003 & Southern Greece & $\begin{array}{l}\text { 6th-7th } \\
\text { century }\end{array}$ & & & & & 0 & 225 & 0.0 \\
\hline $\begin{array}{l}\text { Lieverse } \\
{[417]}\end{array}$ & 2008 & Padova, Italy & & & 1 & & 1 & 1 & 213 & 4.7 \\
\hline Bisel [418] & 1991 & $\begin{array}{l}\text { Herculaneum, } \\
\text { Italy }\end{array}$ & $79 \mathrm{AD}$ & & 1 & & 1 & 1 & 139 & 7.2 \\
\hline \multicolumn{11}{|l|}{$\begin{array}{l}\text { Mid-Eastern/ } \\
\text { Egyptian } \\
\text { peoples }\end{array}$} \\
\hline $\begin{array}{l}\text { Goldstein et } \\
\text { al. [419] }\end{array}$ & 1976 & Tel Sheva, Negev & $200 \mathrm{BC}$ & & & & & 0 & 73 & 0.0 \\
\hline Ortner [420] & 1979 & $\begin{array}{l}\text { Bâb edh-Dhrâ, } \\
\text { Jordan }\end{array}$ & $\begin{array}{l}\text { Early Bronze } \\
\text { Age } \\
(3150-2200 \\
\text { BC) }\end{array}$ & & 1 & 1 & & 1 & 92 & 10.9 \\
\hline $\begin{array}{l}\text { Mathieson et } \\
\text { al. [421] }\end{array}$ & 1997 & $\begin{array}{l}\text { Gisr el-Mudir, } \\
\text { Saqqara, Egypt }\end{array}$ & $\begin{array}{l}2890-2650 \\
\text { BC }\end{array}$ & & & & & 1 & 24 & 41.7 \\
\hline \multicolumn{11}{|l|}{$\begin{array}{l}\text { Indigenous } \\
\text { peoples }\end{array}$} \\
\hline $\begin{array}{l}\text { Lahr and } \\
\text { Bowan [422] }\end{array}$ & 1992 & $\begin{array}{l}\text { Kechipawan, } \\
\text { New Mexico }\end{array}$ & $1300-1600$ & & & & & 0 & 54 & 0.0 \\
\hline Pfeiffer [423] & 1984 & $\begin{array}{l}\text { Uxbridge, } \\
\text { Ontario }\end{array}$ & 1490 & & & & & 1 & $312^{\wedge}$ & 3.2 \\
\hline $\begin{array}{l}\text { Clabeaux } \\
{[424]}\end{array}$ & 1977 & $\begin{array}{l}\text { Fort Erie, } \\
\text { Niagara River, } \\
\text { Ontario }\end{array}$ & $\begin{array}{l}\text { Pre- } \\
\text { colonization }\end{array}$ & & & & & 2 & 286 & 7.0 \\
\hline $\begin{array}{l}\text { Wakefield et } \\
\text { al. [425] }\end{array}$ & 1937 & $\begin{array}{l}\text { Eastern } \\
\text { Arkansas }\end{array}$ & $\begin{array}{l}\text { Pre- } \\
\text { colonization }\end{array}$ & & & & 1 & 1 & 100 & 10.0 \\
\hline $\begin{array}{l}\text { Gregg et al. } \\
\text { [426] }\end{array}$ & 1981 & $\begin{array}{l}\text { Crow Creek, } \\
\text { South Dakota }\end{array}$ & 14th century & 1 & 1 & & 1 & 486 & 2.1 & 1 \\
\hline Miles [427] & 1975 & $\begin{array}{l}\text { Mesa Verde, } \\
\text { Colorado }\end{array}$ & $750-1300 \mathrm{AD}$ & & & & & 0 & 179 & 0.0 \\
\hline $\begin{array}{l}\text { Goldstein } \\
\text { [428] }\end{array}$ & 1957 & Texas & $800-1700 \mathrm{AD}$ & & & & & 0 & 146 & 0.0 \\
\hline
\end{tabular}


TABLE 7: Continued.

\begin{tabular}{|c|c|c|c|c|c|c|c|c|c|c|}
\hline Study & Year & $\begin{array}{l}\text { Archeological } \\
\text { location }\end{array}$ & Era & $\mathrm{M}$ & $\mathrm{F}$ & $\mathrm{U}$ & B & No. DDH & No. Skeletons & Prevalence \\
\hline $\begin{array}{l}\text { Loveland et } \\
\text { al. [429] }\end{array}$ & 1985 & $\begin{array}{l}\text { Red River } \\
\text { County, Texas }\end{array}$ & $\begin{array}{l}1100-1800 \\
\mathrm{AD}\end{array}$ & & & & & 1 & 75 & \\
\hline $\begin{array}{l}\text { Wheeler } \\
{[430]}\end{array}$ & & $\begin{array}{l}\text { El Morro Valley, } \\
\text { New Mexico }\end{array}$ & 13th Century & & & & & 0 & 26 & 0.0 \\
\hline $\begin{array}{l}\text { Merbs and } \\
\text { Vestergaard } \\
{[431]}\end{array}$ & 1985 & $\begin{array}{l}\text { Sundown, } \\
\text { Prescott, } \\
\text { Arizona }\end{array}$ & $\begin{array}{l}1100-1200 \\
\mathrm{AD}\end{array}$ & & & & & 0 & 26 & 0.0 \\
\hline $\begin{array}{l}\text { Drusini et al. } \\
\text { [432] }\end{array}$ & 1987 & $\begin{array}{l}\text { Maguana, Santo } \\
\text { Domingo }\end{array}$ & $\begin{array}{l}\text { late } 15 \text { th } \\
\text { century }\end{array}$ & 3 & 2 & & & 5 & 108 & 46.3 \\
\hline $\begin{array}{l}\text { Western } \\
\text { Europe }\end{array}$ & & & & 8 & 16 & 12 & 6 & 25 & 5089 & 4.9 \\
\hline $\begin{array}{l}\text { Eastern } \\
\text { Europe }\end{array}$ & & & & 1 & 3 & 1 & 0 & 4 & 668 & 6.0 \\
\hline $\begin{array}{l}\text { Mediterra- } \\
\text { nean }\end{array}$ & & & & 0 & 2 & 0 & 2 & 2 & 577 & 3.5 \\
\hline Middle East & & & & 0 & 1 & 1 & 0 & 2 & 189 & 10.6 \\
\hline Indigenous & & & & 0 & 4 & 3 & 1 & 11 & 1798 & 6.1 \\
\hline All & & & & 9 & 26 & 17 & 9 & 44 & 8321 & 5.3 \\
\hline
\end{tabular}

$\wedge^{\wedge}$ The skeletal remains derived from an ossuary make it impossible to reconstruct each individual from the commingled bones; the minimal number of individual skeletons is given. This results in a prevalence that cannot exceed the number calculated but may be less if there were more individuals represented in the ossuary.

[417]. In a study of 225 skeletons from Southern Greece in the 6th-7th centuries $\mathrm{AD}$ there were no cases of $\mathrm{DDH}[416]$.

3.14.2. Mid-Eastern/Egyptians. In the early Bronze Age (3150-2200 BC) people of Bâb edh-Dhrâ, Jordan, there was one case of DDH in 92 skeletons [420]. None of 73 Bedouin skeletons (200 BC) from Tel Sheva, Israel, demonstrated DDH [419]. In 24 skeletons from Gisr el-Mudir, Saqqara, Egypt during the 2nd Dynasty (2890-2650 BC), there was one case of DDH [421].

3.14.3. Native Americans. The first natives encountered by Christopher Columbus were the Taino people [480]. In 102 Taino skeletons dated from the late 15th century found at Juan Dolio, Maguana, Santo Domingo, Dominican Republic [432], 5 cases of DDH were noted. In 100 Mound Builder peoples' skeletons along the Mississippi River in eastern Arkansas [425], (precolonization era, before 1500), there was one unilateral case of DDH. In 75 Caddo-Indian peoples who lived in what is now the Red River county, Eastern Texas (1100-1800 AD) [429], there was one DDH. In the Ontario Uxbridge Iroquoian ossuary ( $\sim 1490 \mathrm{AD})$, one DDH was seen in 312 skeletons [423]. In 286 skeletons from the Fort Erie, Niagara River, Ontario (precolonization era), two cases of DDH were noted [424]. In 486 Native American Crow Creek villagers massacred in the 14th century on the east bank of the Missouri River in South Dakota [426], one DDH was found (a 6-10 years old child). In 54 skeletons from the Kechipawan Pueblo, New Mexico (1300-1600 AD), no DDH was seen [422]. In two small series of 26 skeletons each from El Morro Valley, New Mexico (13th century) [430] and Sundown, Prescott, Arizona (1100-1200 AD) [431], there were no cases of DDH.

The overall gender and laterality mix in the archeological samples is very similar to the composite results in this paper (Table 7). In those skeletons with DDH where the data was known, $74 \%$ were female and 35\% demonstrated bilateral involvement, similar to the figures of $76 \%$ female and $27 \%$ bilateral in this paper. The prevalence of DDH in these archeological samples, even though most are small in size except for that from the Spitalfields cemetery, demonstrates differences compared to the incidence of DDH in this paper. Those for Western Europe are similar (4.9 archeological, 3.6 present United Kingdom). All others were different: Eastern Europe (6.0 archeological, 35.8 present), Mediterranean (3.5 archeological, 25.5 present), Middle East (10.6 archeological, 6.2 present), and indigenous Native Americans (6.1 archeological, 76.1 present). If the sampling of the archeological data set was adequate, then statistical analysis should determine if such differences were real. We subjected the data to the Fisher two-tailed exact test, analyzing for differences between the archeological data and the present data. These data (DDH $n /$ total $n$ ) and (archeological versus present) were 25/5089 and 3232/906428 for Western Europe; $4 / 668$ and 12452/348031 for Eastern Europe; 2/577 and 2240/87581 for Mediterranean; 2/189 and 732/118225 for Arabic Middle East; 44/8321 and 1108/14553 for indigenous Native Americans. There were no differences for Western Europe $(P=0.12)$ and the Middle East Arabic $(P=$ $0.33)$, while there were differences for Eastern Europe and indigenous Native Americans $(P<0.001)$. These differences 


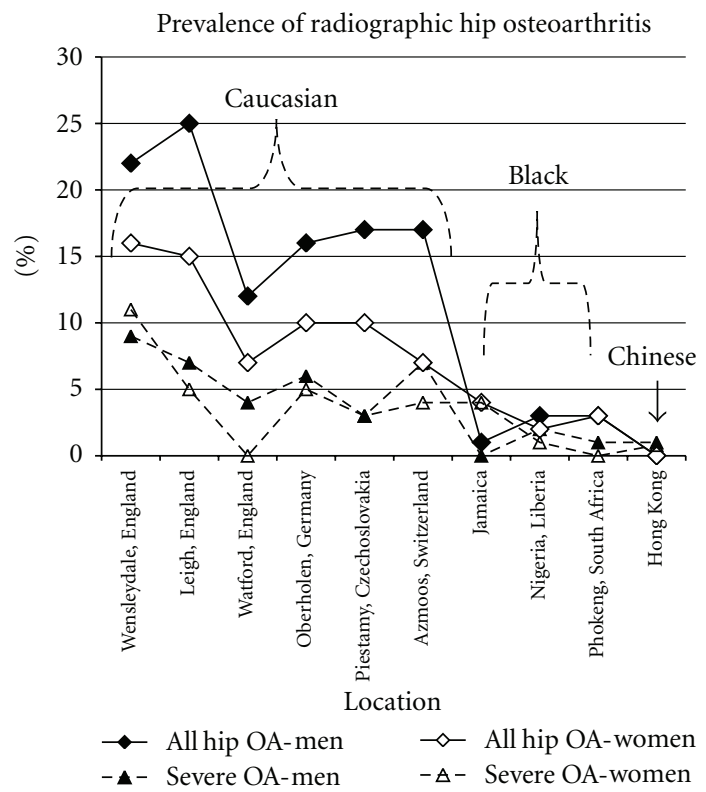

(a)

THR rates by age and race-men

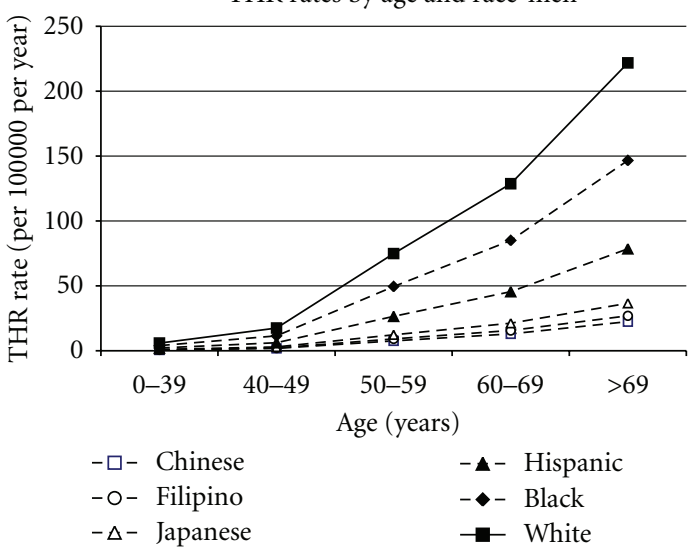

(b1)

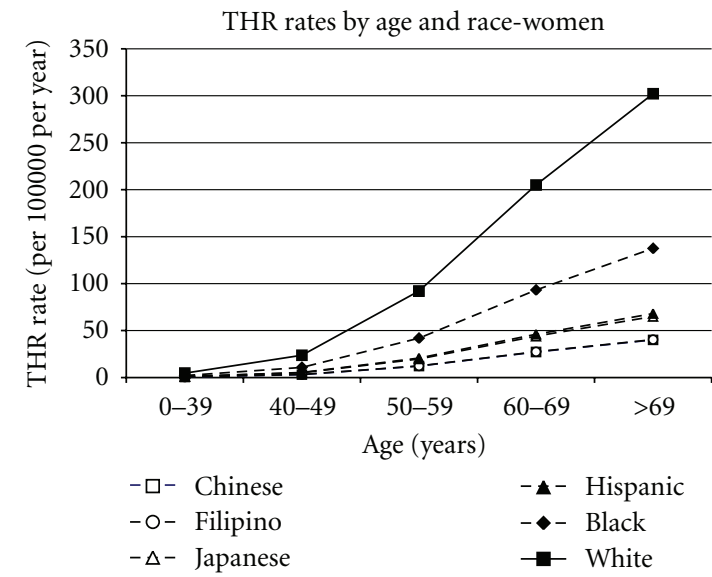

(b2)

(b)

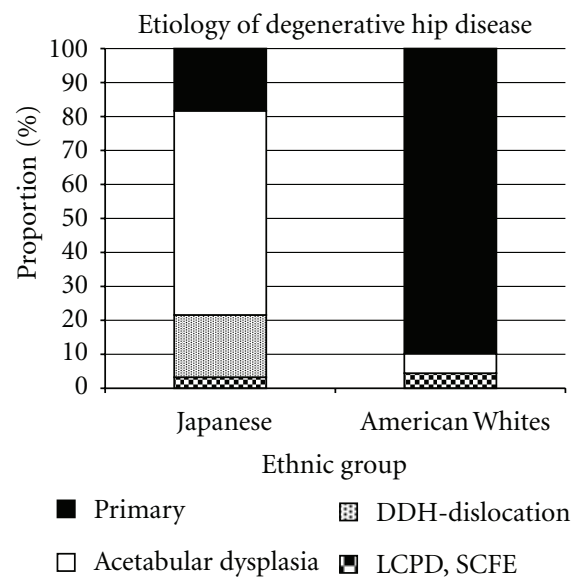

(c)

FIgURE 5: The demographics of hip osteoarthritis in adults. (a) Radiographic prevalence of hip osteoarthritis by ethnicity and geographic location. Data from Lau et al. [472]. (b1) Estimated rates of total hip replacements for primary coxarthrosis in San Francisco, 1984-1988, for men. Data from Hoaglund et al. [473]. (b2) Estimated rates of total hip replacements for primary coxarthrosis in San Francisco, 1984-1988, for women. Data from Hoaglund et al. [473]. (c) Differences in the etiology of adult hip arthritis between Japanese and Caucasian patients. Note the rarity of SCFE and Perthes' as a cause of adult hip arthritis. Data from Hoaglund et al. [474]. 
may represent changing epidemiology, changes in natural selection processes in the archeological era, or inadequate sampling of the archeological materials. Further inquiry will be needed in this subject area.

\section{Conclusion}

DDH demonstrates a predominance of left-sided $(64.0 \%)$ and unilateral involvement (63.4\%). The incidence per 1000 live births ranges from 0.06 in Africans in Africa to 76.1 in Native Americans with significant variability between and within racial groups and geographic location. The incidence of clinical neonatal hip instability at birth ranges from 0.4 in Africans to 61.7 in Polish Caucasians. Predictors of $\mathrm{DDH}$ are breech presentation, positive family history, and gender (female). Ligamentous laxity and abnormalities in collagen metabolism, estrogen metabolism, and pregnancyassociated pelvic instability are well-described associations with DDH. Many studies demonstrate an increase of DDH in the winter, both in the Northern and Southern hemispheres. Swaddling is strongly associated with DDH. Associated conditions are congenital muscular torticollis and congenital foot deformities. The opposite hip is frequently abnormal when using rigorous radiographic assessments. Archeological studies demonstrate that the epidemiology of DDH may be changing.

\section{Acknowledgments}

This study was supported in part by the Garceau Professorship Endowment, Department of Orthopaedic Surgery, Indiana University School of Medicine, and the George Rapp Pediatric Orthopaedic Research Endowment, Riley Children's Foundation, Riley Children's Hospital, Indianapolis, Indiana.

\section{Disclosure}

The authors otherwise have no financial interests with any other organizations or bodies. As a systematic literature review, Institutional Review Board approval is not applicable. This was the 1st of three presentations on the epidemiology and demographics of pediatric hip disorders given at the $\mathrm{AO}$ North American Symposium on Surgical Preservation of the Hip, Squaw Valley, Calif, January 2009.

\section{References}

[1] T. L. Stedman, Stedman's Medical Dictionary, Williams and Wilkins, Baltimore, Md, USA, 26th edition, 1995.

[2] M. S. Kocher and D. Zurakowski, "Clinical epidemiology and biostatistics: a primer for orthopaedic surgeons," Journal of Bone and Joint Surgery, American, vol. 86, no. 3, pp. 607-620, 2004.

[3] R. M. Szabo, "Principles of epidemiology for the orthopaedic surgeon," Journal of Bone and Joint Surgery, American, vol. 80, no. 1, pp. 111-120, 1998.

[4] A. MacFarlane, "Congenital dislocation of the hip-an epidemiological conunmdrum," Maternal and Child Health Journal, pp. 13-15, 1980.
[5] C. J. Homer, R. D. Baltz, G. B. Hickson et al., "Clinical practice guideline: early detection of developmental dysplasia of the hip," Pediatrics, vol. 105, no. 4 I, pp. 896-905, 2000.

[6] D. D. Aronsson, M. J. Goldberg, T. F. Kling, and D. R. Roy, "Developmental dysplasia of the hip," Pediatrics, vol. 94, no. 2 I, pp. 201-208, 1994.

[7] A. Chan, K. A. McCaul, P. J. Cundy, E. A. Haan, and R. ByronScott, "Perinatal risk factors for developmental dysplasia of the hip," Archives of Disease in Childhood, vol. 76, no. 2, pp. F94-F100, 1997.

[8] A. Chan, B. K. Foster, and P. J. Cundy, "Problems in the diagnosis of neonatal hip instability," Acta Paediatrica, vol. 90, no. 8, pp. 836-839, 2001.

[9] H. T. Harcke, "Developmental dysplasia of the hip: a spectrum of abnormality," Pediatrics, vol. 103, no. 1, p. 152, 1999.

[10] S. J. Krikler and N. S. P. Dwyer, "Comparison of results of two approaches to hip screening in infants," Journal of Bone and Joint Surgery, British, vol. 74, no. 5, pp. 701-703, 1992.

[11] M. Larchet, J. M. Bourgeois, P. Billon et al., "Neonatal screening of congential hip dislocation: comparative study in Breton and Mediterranean populations," Archives de Pédiatrie, vol. 1, no. 12, pp. 1093-1099, 1994.

[12] A. Masse, "History and epidemiology of congenital dislocation of the hip in Brittany," Acta Orthopaedica Belgica, vol. 56, no. 1 A, pp. 43-52, 1990.

[13] S. Wientroub and F. Grill, "Ultrasonography in developmental dysplasia of the hip," Journal of Bone and Joint Surgery, American, vol. 82, no. 7, pp. 1004-1008, 2000.

[14] N. M. P. Clarke, "Role of ultrasound in congenital hip dysplasia," Archives of Disease in Childhood, vol. 70, no. 5, pp. 362-363, 1994.

[15] A. Tegnander, K. J. Holen, and T. Terjesen, "The natural history of hip abnormalities detected by ultrasound in clinically normal newborns. A 6-8 year radiographic followup study of 93 children," Acta Orthopaedica Scandinavica, vol. 70, no. 4, pp. 335-337, 1999.

[16] D. J. Sucato, C. E. Johnston, J. G. Birch, J. A. Herring, and P. Mack, "Outcome of ultrasonographic hip abnormalities in clinically stable hips," Journal of Pediatric Orthopaedics, vol. 19, no. 6, pp. 754-759, 1999.

[17] A. Roposch and J. G. Wright, "Increased diagnostics information and understanding disease: uncertainty in the diagnosis of developmental hip dysplasia," Radiology, vol. 242, no. 2, pp. 355-359, 2007.

[18] T. Terjesen, K. J. Holen, and A. Tegnander, "Hip abnormalities detected by ultrasound in clinically normal newborn infants," Journal of Bone and Joint Surgery, British, vol. 78, no. 4, pp. 636-640, 1996.

[19] B. Stover, R. Bragelmann, A. Walther, and F. Ball, "Development of late congenital hip dysplasia significance of ultrasound screening," Pediatric Radiology, vol. 23, no. 1, pp. 19-22, 1993.

[20] D. Baronciani, G. Atti, F. Andiloro et al., "Screening for developmental dysplasia of the hip: from theory to practice. Collaborative Group DDH Project," Pediatrics, vol. 99, no. 2, p. E5, 1997.

[21] J. J. Rombouts and R. Rissillon, "Natural history of congenital hip dislocation during the first year of life," Acta Orthopaedica Belgica, vol. 56, pp. 125-139, 1990.

[22] J. L. Kelsey, "The epidemiology of diseases of the hip: a review of the literature," International Journal of Epidemiology, vol. 6, no. 3, pp. 269-280, 1977. 
[23] R. Graf, "Classification of hip joint dysplasia by means of sonography," Archives of Orthopaedic and Trauma Surgery, vol. 102, pp. 248-255, 1984.

[24] A. Roposch, R. Graf, and J. G. Wright, "Determining the reliability of the Graf classification for hip dysplasia," Clinical Orthopaedics and Related Research, no. 447, pp. 119-124, 2006.

[25] J. A. Herring, Tachdjian's Pediatric Orthopaedics, Saunders Elsevier, Philadelphia, Pa, USA, 4th edition, 2008.

[26] V. Bialik, G. M. Bialik, S. Blazer, P. Sujov, F. Wiener, and M. Berant, "Developmental dysplasia of the hip: a new approach to incidence," Pediatrics, vol. 103, no. 1, pp. 93-99, 1999.

[27] K. Rosendahl, T. Markestad, and R. T. Lie, "Congenital dislocation of the hip: a prospective study comparing ultrasound and clinical examination," Acta Paediatrica, vol. 81, no. 2, pp. 177-181, 1992.

[28] K. N. Joseph and S. Meyer, "Discrepancies in ultrasonography of the infant hip," Journal of Pediatric Orthopaedics Part B, vol. 5, no. 4, pp. 273-278, 1996.

[29] K. Rosendahl, A. Aslaksen, R. T. Lie, T. Markestad, and H. T. Harcke, "Reliability of ultrasound in the early diagnosis of developmental dysplasia of the hip," Pediatric Radiology, vol. 25, no. 3, pp. 219-224, 1995.

[30] E. Bar-On, S. Meyer, G. Harari, and S. Porat, "Ultrasonography of the hip in developmental hip dysplasia," Journal of Bone and Joint Surgery, British, vol. 80, no. 2, pp. 321-324, 1998.

[31] J. J. Dias, I. H. Thomas, A. C. Lamont, B. S. Mody, and J. R. Thompson, "The reliability of ultrasonographic assessment of neonatal hips," Journal of Bone and Joint Surgery, British, vol. 75, no. 3, pp. 479-482, 1993.

[32] V. Hadlow, "Neonatal screening for congenital dislocation of the hip. A prospective 21-year survey," Journal of Bone and Joint Surgery, British, vol. 70, no. 5, pp. 740-743, 1988.

[33] T. G. Barlow, "Early diagnosis and treatment of congenital dislocation of the hip," Journal of Bone and Joint Surgery, British, vol. 44, pp. 292-301, 1962.

[34] F. Abdinejad, J. Takapouy, and N. Eskandari, "Incidence of congenital dislocation of the hip in Shiraz," Journal of Medical Council of Islamic Republic of Iran, vol. 9, pp. 275-280, 1996.

[35] P. B. Eveleth and J. M. Tanner, Worldwide Variation in Human Growth, Cambridge University Press, Cambridge, UK, 2nd edition, 1990.

[36] C. Corrigan and S. Segal, "The incidence of congenital dislocation of the hip at Island Lake, Manitoba," Canadian Medical Association Journal, vol. 62, no. 6, pp. 535-540, 1950.

[37] J. M. Walker, "Congenital hip disease in a Cree-Ojibwa population: a retrospective study," Canadian Medical Association Journal, vol. 116, no. 5, pp. 501-504, 1977.

[38] C. S. Houston and R. H. Buhr, "Swaddling of Indian infants in northern Saskatchewan," Musk-ox, vol. 36, pp. 5-14, 1988.

[39] R. B. Salter, "Etiology, pathogenesis and possible prevention of congenital dislocation of the hip," Canadian Medical Association Journal, vol. 98, no. 20, pp. 933-945, 1968.

[40] D. L. Rabin, C. R. Barnett, W. D. Arnold, R. H. Freiberger, and G. Brooks, "Untreated congenital hip disease. A study of the epidemiology, natural history and social aspects of the disease in a Navajo population," American Journal of Public Health and the Nation's Health, vol. 55, pp. 1-44, 1965.

[41] W. B. Pratt, R. H. Freiberger, and W. D. Arnold, "Untreated congenital hip dysplasia in the Navajo," Clinical Orthopaedics and Related Research, vol. 162, pp. 69-77, 1982.
[42] S. S. Coleman, "Congenital dysplasia of the hip in the Navajo infant," Clinical Orthopaedics and Related Research, vol. 56, pp. 179-193, 1968.

[43] B. S. Kraus and J. R. Schwartzman, "Congenital dislocation of the hip among the Fort Apache Indians," Journal of Bone and Joint Surgery, American, vol. 39, pp. 448-449, 1957.

[44] C. Bower, F. J. Stanley, and A. Kricker, "Congenital dislocation of the hip in Western Australia. A comparison of neonatally and postneonatally diagnosed cases," Clinical Orthopaedics and Related Research, no. 224, pp. 37-44, 1987.

[45] B. Getz, "The hip joint in Lapps and its bearing on the problem of congenital dislocation," Acta Orthopaedica Scandinavica, vol. 25, supplement 18, 1955.

[46] T. Mellbin, "The children of Swedish nomad Lapps. VII. Congenital malformations," Acta Orthopaedica Scandinavica, vol. 131, supplement, pp. 62-66, 1962.

[47] J. Edelstein, "Congenital dislocation of the hip in the Bantu," Journal of Bone and Joint Surgery, British, vol. 48, no. 7, p. 397, 1966.

[48] A. Roper, "Hip dysplasia in the Arican Bantu," Journal of Bone and Joint Surgery, British, vol. 58, no. 2, pp. 155-158, 1976.

[49] H. F. Pompe van Meerdervoort, "Congenital musculoskeletal disorders in the South African negro," Journal of Bone and Joint Surgery, British, vol. 59, p. 257, 1977.

[50] S. W. Burke, T. I. Macey, J. M. Roberts, and C. Johnston, "Congenital dislocation of the hip in the American black," Clinical Orthopaedics and Related Research, vol. 192, pp. 120123, 1985.

[51] W. H. Finley, K. H. Gustavson, T. M. Hall, D. C. Hurst, C. M. Barganier, and J. A. Wiedmeyer, "Birth defects surveillance: Jefferson County, Alabama, and Uppsala County, Sweden," Southern Medical Journal, vol. 87, no. 4, pp. 440-445, 1994.

[52] R. Kulshrestha, L. M. Nath, and P. Upadhyaya, "Congenital malformations in live born infants in a rural community," Indian Pediatrics, vol. 20, no. 1, pp. 45-49, 1983.

[53] M. Singh and N. K. Sharma, "Spectrum of congenital malformations in the newborn," The Indian Journal of Pediatrics, vol. 47, no. 3, pp. 239-244, 1980.

[54] N. Y. Boo and T. Rajaram, "Congenital dislocation of hips in Malaysian neonates," Singapore Medical Journal, vol. 30, no. 4, pp. 368-371, 1989.

[55] A. K. Gupta, S. Kumari, P. L. Arora, R. Kumar, A. K. Mehtani, and L. K. Sood, "Hip instability in newborns in an urban community," The National Medical Journal of India, vol. 5, no. 6, pp. 269-272, 1992.

[56] K. C. Ang, E. H. Lee, P. Y. C. Lee, and K. L. Tan, "An epidemiological study of developmental dysplasia of the hip in infants in Singapore," Annals of the Academy of Medicine Singapore, vol. 26, no. 4, pp. 456-458, 1997.

[57] V. Kaushal, S. P. Kaushal, and O. N. Bhakoo, "Congenital dysplasia of the hip in northern india," International Surgery, vol. 61, no. 1, p. 29, 1976.

[58] F. Şahin, A. Aktürk, U. Beyazova et al., "Screening for developmental dysplasia of the hip: results of a 7-year followup study," Pediatrics International, vol. 46, no. 2, pp. 162-166, 2004.

[59] A. Kutlu, R. Memik, M. Mutlu, R. Kutlu, and A. Arslan, "Congenital dislocation of the hip and its relation to swaddling used in Turkey," Journal of Pediatric Orthopaedics, vol. 12, no. 5, pp. 598-602, 1992.

[60] H. Doğruel, H. Atalar, O. Y. Yavuz, and U. Şayli, "Clinical examination versus ultrasonography in detecting developmental dysplasia of the hip," International Orthopaedics, vol. 32, no. 3, pp. 415-419, 2008. 
[61] I. Alkalay, "Detection and treatment of congenital hip dislocation in babies at risk in Western Galilee," Israel Journal of Medical Sciences, vol. 16, no. 4, pp. 245-246, 1980.

[62] N. K. Moosa, P. T. Kumar, and S. M. Mahmoodi, "Incidence of developmental dysplasia of the hip in Dubai," Saudi Medical Journal, vol. 30, no. 7, pp. 952-955, 2009.

[63] T. Mirdad, "Incidence and pattern of congenital dislocation of the hip in Aseer region of Saudi Arabia," West African journal of medicine, vol. 21, no. 3, pp. 218-222, 2002.

[64] L. G. Danielsson, "Instability of the hip in neonates: an ethnic and geographical study in 24101 newborn infants in Malmo," Journal of Bone and Joint Surgery, British, vol. 82, no. 4, pp. 545-547, 2000.

[65] G. H. Mamouri, F. Khatami, and A. B. Hamedi, "Congenital dislocation of the hip in newborns of Mashhad City," The Internet Journal of Pediatrics and Neonatology, vol. 4, no. 1, 2004.

[66] N. Pashapour and S. Golmahammadlou, "Study on the diagnosis time of developmental dysplasia of the hip," Eastern Mediterranean Health Journal, vol. 13, no. 2, pp. 465-469, 2007.

[67] D. C. Paterson, "The early diagnosis and treatment of congenital dislocation of the hip," Clinical Orthopaedics and Related Research, vol. 119, pp. 28-38, 1976.

[68] S. Rao and A. J. Thurston, "Congenital dislocation of hip in the newborn: a postnatal survey," New Zealand Medical Journal, vol. 99, no. 811, pp. 752-754, 1986.

[69] R. B. Lowry, N. Y. Thunem, and S. Anderson-Redick, "Alberta congenital anomalies surveillance system," Canadian Medical Association Journal, vol. 14, pp. 1159-1155, 1989.

[70] J. H. Medalie, M. Makin, E. Alkalay, J. Yofe, Z. Cochavi, and D. Ehrlich, "Congenital dislocation of the hip-a clinicalepidemiological study, Jerusalem 1954 to 1960. I. Retrospective incidence study," Israel Journal of Medical Sciences, vol. 2, no. 2, pp. 212-217, 1966.

[71] S. Harlap, A. M. Davies, M. Haber, H. Rossman, R. Prywes, and N. Samueloff, "Congenital malformations in the Jerusalem perinatal study. An overview with special reference to maternal origin," Israel Journal of Medical Sciences, vol. 7, no. 12, pp. 1520-1528, 1971.

[72] S.-C. Huang, H.-C. Liu, C.-F. Chen, C.-L. Chen, and T.K. Liu, "Incidence of congenital dislocation of the hip in Chinese," Journal of Orthopaedic Surgery, vol. 5, pp. 53-62, 1988.

[73] C.-H. Chang, Y.-T. Chiang, Z.-L. Lee, and K. N. Kuo, "Incidence of surgery in developmental dysplasia of the hip in Taiwan," Journal of the Formosan Medical Association, vol. 106, pp. 462-466, 2007.

[74] F. T. Hoaglund, A. Kalamchi, and R. Poon, "Congenital hip dislocation and dysplasia in southern Chinese," International Orthopaedics, vol. 4, no. 4, pp. 243-246, 1981.

[75] M. Limpaphayom, S. Bhongsvej, and S. P. Chitimanda, "Orthopaedic problems in the newborn," Journal of The Medical Association of Thailand, vol. 58, pp. 363-367, 1975.

[76] M. Limpaphayom, P. Jeeravipoolvarn, and U. Chomcharn, "Congenital hip dysplasia in Thai children," Journal of the Medical Association of Thailand, vol. 61, no. 10, pp. 565-569, 1978.

[77] K. Naito, "Congenital dislocation of the hip," Journal of Japanese Orthopaedic Association, vol. 13, p. 1086, 1958.

[78] F. Akabayashi, "Studies on $\mathrm{CDH}$ and restricted abduction of the hip joint as observed in mass examination of sucklings and infants," Journal of Japanese Orthopaedic Association, vol. 32, pp. 9-35, 1958.
[79] K. Tsuji, "On the diagnositic results of CDH in babies," Japanese Medical Journal, vol. 2116, pp. 14-18, 1964.

[80] D. Kashiwagi and K. Kagawa, "Congenital dislocation of the hip in Kobe," Kobe Journal of Medical Sciences, vol. 11, pp. 79-85, 1965.

[81] K. Haginomori, "A statistical study of congenital dislocation of the hip in the south-western part of Kochi prefecture," Shikoku Acta Medica, vol. 22, pp. 112-125, 1966.

[82] G. Tanabe, K. Kotakemori, Y. Miyake, and M. Mohri, "Early diagnosis of congenital dislocation of the hip," Acta Orthopaedica Scandinavica, vol. 43, pp. 511-522, 1972.

[83] N. Wada, N. Kato, S. Mori, H. Abe, and N. Hirano, ". Evaluation of screening for congenital dislocation of the hip in Tokushima Prefecture," in Prevention of Congenital Dislocation of the Hip in Infants: Experience and Results in Japan, M. Ando, Ed., pp. 39-42, Yamada Company, Asahikawa, Japan, 1993.

[84] K. Ishida, "Prevention of the onset of congenital dislocation of the hip," in Prevention of Congenital Dislocation of the Hip in Infants: Experience and Results in Japan, M. Ando, Ed., pp. 1-10, Yamada Company, Asahikawa, Japan, 1993.

[85] K. Ishida, "Prevention of the development of the typical dislocation of the hip," Clinical Orthopaedics and Related Research, vol. 126, pp. 167-169, 1977.

[86] A. Kikuike, T. Matsunaga, Y. Miyata, K. Takahashi, and M. Sohmiya, "Changes in the detection rate during infantile screening for congenital dislocation of the hip at two cities in Gifu Prefecture," in Prevention of Congenital Dislocation of the Hip in Infants: Experience and Results in Japan, M. Ando, Ed., pp. 31-36, Yamada Company, Asahikawa, Japan, 1993.

[87] E. Gotoh, M. Ando, S. Inao, and S. Suzuki, "The present state of screening for congenital dislocation of the hip in Asahikawa," in Prevention of Congenital Dislocation of the Hip in Infants: Experience and Results in Japan, M. Ando, Ed., pp. 11-16, Yamada Company, Asahikawa, Japan, 1993.

[88] K. Saito, "Checks of infants for hip joint abnormalities at the Sapporo City Toyohira Public Health Center: analysis of data from 1974 to 1988," in Prevention of Congenital Dislocation of the Hip in Infants: Experience and Results in Japan, M. Ando, Ed., pp. 17-18, Yamada Company, Asahikawa, Japan, 1993.

[89] H. Shinohara, "Changes of the incidence in Matsudo city in the past 20 years," in Prevention of Congenital Dislocation of the Hip in Infants: Experience and Results in Japan, M. Ando, Ed., pp. 25-26, Yamada Company, Asahikawa, Japan, 1993.

[90] K. Iwasaki and K. Takahashi, "Annual changes in the incidence of congenital dislocation of the hip in infants and the rate of successful reduction in Nagasaki city," in Prevention of Congenital Dislocation of the Hip in Infants: Experience and Results in Japan, M. Ando, Ed., pp. 43-45, Yamada Company, Asahikawa, Japan, 1993.

[91] F. Higuchi, "Genetic study on the congenital dislocation of the hip," The Bulletin of Tokyo Medical and Dental University, vol. 31, no. 4, pp. 195-207, 1984.

[92] E. Severin, "The incidence of congenital dislocation of the hip and pes equinovarus in Sweden," Nordisk Medicin, vol. 15, pp. 221-223, 1956.

[93] S. von Rosen, "Diagnosis and treatment of congenital dislocation of the hip joint in the new-born," Journal of Bone and Joint Surgery, British, vol. 44, pp. 284-291, 1962.

[94] S. von Rosen, "Further experience with congenital dislocation of the hip in the newborn," Journal of Bone and Joint Surgery, British, vol. 50, no. 3, pp. 538-541, 1968. 
[95] N. Fredensborg, "The effect of early diagnosis of congenital dislocation of the hip," Acta Paediatrica Scandinavica, vol. 65, no. 3, pp. 323-328, 1976.

[96] L. Beckman, R. Lemperg, and M. Nordstrom, "Congenital dislocation of the hip joint in Northern Sweden. Neonatal diagnosis and need for orthopaedic treatment," Clinical Genetics, vol. 11, no. 2, pp. 151-153, 1977.

[97] I. Bjerkreim, "Congenital dislocation of the hip joint in Norway. I. Late-diagnosis CDH," Acta Orthopaedica Scandinavica, vol. 157, Supplement, pp. 1-20, 1974.

[98] I. Bjerkreim, "Congenital dislocation of the hip joint in Norway. II. Detection of late cases," Acta Orthopaedica Scandinavica, vol. 157, Supplement, pp. 21-45, 1974.

[99] I. Bjerkreim, "Congenital dislocation of the hip joint in Norway. III. Neonatal CDH," Acta Orthopaedica Scandinavica, vol. 157, Supplement, pp. 47-74, 1974.

[100] I. Bjerkreim, "Congenital dislocation of the hip joint in Norway. IV. The incidence in southeast Norway," Acta Orthopaedica Scandinavica, vol. 157, Supplement, pp. 75-88, 1974.

[101] I. Bjerkreim and C. B. Van Der Hagen, "Congenital dislocation of the hip joint in Norway. V. Evaluation of genetic and environmental factors," Clinical Genetics, vol. 5, no. 5, pp. 433-448, 1974.

[102] I. Bjerkreim, "Congenital dislocation of the hip joint in Norway. A clinical-epidemiological study," Journal of the Oslo City Hospitals, vol. 26, no. 9-10, pp. 79-90, 1976.

[103] P. H. Finne, I. Dlaeni, N. Ikonomou, G. Ulimoen, and T. W. R. Hansen, "Diagnosis of congenital dysplasia of the hip in the newborn. Evaluation of a screening program," Acta Orthopaedica Scandinavica, vol. 79, pp. 313-320, 2008.

[104] K. K. Melve and R. Skjaerven, "Outcomes of pregnancies following a birth with major birth defects: a population based study," Early Human Development, vol. 84, no. 10, pp. 651657, 2008.

[105] E. Heikkilä, "Congenital dislocation of the hip in Finland. An epidemiologic analysis of 1035 cases," Acta Orthopaedica Scandinavica, vol. 55, pp. 125-129, 1984.

[106] I. Clausen and K. T. Nielsen, "Breech position, delivery route and congenital hip dislocation," Acta Obstetricia et Gynecologica Scandinavica, vol. 67, no. 7, pp. 595-597, 1988.

[107] G. P. Mitchell, "Problems in the early diagnosis and management of congenital dislocation of the hip," Journal of Bone and Joint Surgery, British, vol. 54, no. 1, pp. 4-12, 1972.

[108] I. G. MacKenzie and J. G. Wilson, "Problems encoutered in the early diagnosis and management of congenital dislocation of the hip," Journal of Bone and Joint Surgery, British, vol. 63, no. 1, pp. 38-42, 1981.

[109] P. Bertol, M. F. Macnicol, and G. P. Mitchell, "Radiographic features of neonatal congenital dislocation of the hip," Journal of Bone and Joint Surgery, British, vol. 64, no. 2, pp. 176-179, 1982.

[110] R. G. Record and J. H. Edwards, "Environmental influences related to the aetiology of congenital dislocation of the hip," British Journal of Preventive \& Social Medicine, vol. 12, no. 1, pp. 8-22, 1958.

[111] I. Leck, R. G. Record, T. McKeown, and J. H. Edwards, “The incidence of malformations in Birmingham, England, 19501959," Teratology, vol. 1, no. 3, pp. 263-280, 1968.

[112] J. A. Wilkinson, "A post-natal survey for congenital displacement of the hip," Journal of Bone and Joint Surgery, British, vol. 54, no. 1, pp. 40-49, 1972.
[113] D. Jones, "An assessment of the value of examination of the hip in the newborn," Journal of Bone and Joint Surgery, British, vol. 59, no. 3, pp. 318-322, 1977.

[114] T. C. Noble, C. R. Pullan, A. W. Craft, and M. A. Leonard, "Difficulties in diagnosing and managing congenital dislocation of the hip," British Medical Journal, vol. 2, no. 6137, pp. 620-623, 1978.

[115] J. C. Catford, G. C. Bennet, and J. A. Wilkinson, "Congenital hip dislocation: an increasing and still uncontrolled disability?" British Medical Journal, vol. 285, no. 6354, pp. 15271530, 1982

[116] E. G. Knox, E. H. Armstrong, and R. J. Lancashier, "Effectiveness of screeening for congenital dislocation of the hip," Journal of Epidemiology and Community Health, vol. 41, pp. 283-289, 1987.

[117] J. Williamson, "Difficulties of early diagnosis and treatment of congenital dislocation of the hip in Northern Ireland," Journal of Bone and Joint Surgery, British, vol. 54, no. 1, pp. 13-17, 1972.

[118] C. C. Patterson, W. G. Kernohan, R. A. B. Mollan, P. E. Haugh, and B. P. Trainor, "High incidence of congenital dislocation of the hip in Northern Ireland," Paediatric and Perinatal Epidemiology, vol. 9, no. 1, pp. 90-97, 1995.

[119] J. D. Reerink, W. P. Herngreen, P. H. Verkerk, J. H. Ruys, and S. P. Verloove-Vanhorick, "Congenital anomalies in the first year of life in the Netherlands," Nederlands Tijdschrift voor Geneeskunde, vol. 137, pp. 504-509, 1993.

[120] J. Judet and F. Tanzy, "Detection of congenital hip malformations in the department of Creuse," Pediatrie, vol. 21, no. 7, pp. 860-866, 1966.

[121] J. L. Valdivieso Garcia, F. Blanco Lopez, L. M. Ocana Losa, and A. Romanos Lezcano, "Seasonal incidence in the congenital dislocation of the hip. A risk factor," Anales Espanoles de Pediatria, vol. 31, no. 6, pp. 567-569, 1989.

[122] M. L. Padilla Esteban, A. N. Espert, J. M. G.-S. Pardo, and A. C. de la Mano, "Frequency of congenital dislocation of the hip in 40,243 live births (Part I)," Anales Espanoles de Pediatria, vol. 33, pp. 535-538, 1990.

[123] A. J. M. Sanz, J. Y. Pascual, M. C. P. Garcia, E. O. Cruz, V. S. Villalobos, and I. F. Portan, "A study of risk factors in 130 children with suspected hip dysplasia," Anales Espanoles de Pediatria, vol. 35, pp. 409-412, 1991.

[124] C. Giannakopoulou, A. Aligizakis, E. Korakaki et al., "Neonatal screening for developmental dysplasia of the hip on the maternity wards in Crete, Greece. Correlation to risk factors," Clinical and Experimental Obstetrics and Gynecology, vol. 29, no. 2, pp. 148-152, 2002.

[125] D. Di Bella, G. F. Di Fede, M. Valastro, and V. Rampulla, "Congenital hip dysplasia in Sicily," La Pediatria Medica $e$ Chirurgica, vol. 19, no. 4, pp. 291-294, 1997.

[126] F. Srakar, "Problem urodenog iscasenja kuka (LCC) u Sloveniji," Acta Orthopaedica Lugoslavica, vol. 17, pp. 134137, 1986.

[127] D. I. Kepeski, B. Balancevski, Z. Prilepcanska, and S. Curceski, "Nasi rezultti utvrdivanja ucestalosti i ranog lecenja kongenitalne luksacije kuka u Skoplju," in OrtopeskoTraumatoloski dana Jugoslavije, V. Zi, Ed., pp. 284-291, Ohrid, Juot, Yugoslavia, 1969.

[128] A. Maričević, "Incidence of congenital hip dislocation on the Lastovo Island in the period from 1885 to 1993," Lijecnicki Vjesnik, vol. 117, pp. 126-129, 1995.

[129] I. Krolo, K. Visković, S. Kozic et al., "The advancement in the early diagnostics of developmental hip dysplasia in infantsthe role of ultrasound screeming," Collegium Antropoligicum, vol. 27, pp. 627-634, 2003. 
[130] S. Stipanicev, "The effect of prenatal and postnatal factors in the etiology of congenital hip dysplasia," Lijecnicki Vjesnik, vol. 107, pp. 370-375, 1985.

[131] A. V. Darmonov, "Clinical screening for congenital dislocation of the hip," Journal of Bone and Joint Surgery, American, vol. 78, no. 3, pp. 383-388, 1996.

[132] B. Samborska and S. Lembrych, "Congenital dysplasia and congenital luxation of the hip joint in newborns. Assessment of the course of pregnancy and labor," Ginekologia Polska, vol. 56, pp. 102-107, 1986.

[133] D. Polívka, "Incidence of dysplasia of the hip in the CSSR," Acta Chirurgiae Orthopaedicae et Traumatologiae Cechoslovaca, vol. 40, pp. 507-515, 1973.

[134] P. Košek, "Seasonal occurrence of the frequency of the hip dysplasia-a contribution to its etiology," Acta Chirurgiae Orthopaedicae et Traumatologiae Cechoslovaca, vol. 40, pp. 208-215, 1973.

[135] J. Poul, J. Bajerova, M. Sommernitz, M. Straka, M. Pokorny, and F. Y. H. Wong, "Early diagnosis of congenital dislocation of the hip," Journal of Bone and Joint Surgery, British, vol. 74, no. 5, pp. 695-700, 1992.

[136] Š. Vencálková and J. Janata, "Evaluation of screening for developmental dysplasia of the hip in the Liberec region in 1984-2005," Acta Chirurgiae Orthopaedicae et Traumatologiae Cechoslovaca, vol. 76, pp. 218-224, 2009.

[137] J. Drimal, "The role of exogenous factors in etiology of congenital hip dislocation: socio-epidemilogical study," Acta Chirurgiae Orthopaedicae et Traumatologiae Cechoslovaca, vol. 56, pp. 457-464, 1959.

[138] V. Tomáš, "Incidence and treatment of inborn dysplasia of the hip joint in the region of Bardejov in the period of 19841988," Acta Chirurgiae Orthopaedicae et Traumatologiae Cechoslovaca, vol. 56, pp. 502-506, 1989.

[139] A. Czéizel, J. Szentpetery, and M. Kellermann, "Incidence of congenital dislocation of the hip in Hungary," British Journal of Preventive and Social Medicine, vol. 28, no. 4, pp. 265-267, 1974.

[140] P. Csató and A. Benkó, "Systematic examination of newborn infants in the interest of early treatment of dislocation of the hip," Beitrage zur Orthopadie und Traumatologie, vol. 10, pp. 801-805, 1963.

[141] K. Pap, "Effect of seasons of the year on on incidence of congenital hip dislocations," Zantrablatt fur Chirurgie, vol. 81, pp. 2388-2389, 1956.

[142] A. Czeizel, T. Vizkelety, and J. Szentpéteri, "Congenital dislocation of the hip in Budapest, Hungary," British journal of Preventive \& Social Medicine, vol. 26, no. 1, pp. 15-22, 1972.

[143] B. C. Yiv, R. Saidin, P. J. Cundy et al., "Developmental dysplasia of the hip in South Australia in 1991: prevalence and risk factors," Journal of Paediatrics and Child Health, vol. 33, no. 2, pp. 151-156, 1997.

[144] A. Chan, P. J. Cundy, B. K. Foster, R. J. Earne, and R. B. Scott, "Late diagnosis of congenital dislocation of the hip and presence of a screening programe: south Australian population-based study," The Lancet, vol. 354, pp. 15141517, 1999.

[145] R. N. Howie and L. I. Phillips, "Congenital malformations in the newborn: a survey at the National Women's Hospital, 1964-67," New Zealand Medical Journal, vol. 71, no. 453, pp. 65-71, 1970.

[146] J. R. Doig and F. T. Shannon, "Congenital dislocation of the hip; an evaluation of neonatal diagnosis," New Zealand Medical Journal, vol. 82, no. 553, pp. 367-369, 1975.
[147] R. G. Dykes, "Congenital dislocation of the hip in Southland," New Zealand Medical Journal, vol. 81, no. 540, pp. 467470, 1975.

[148] E. C. H. Lehmann and D. G. Street, "Neonatal screening in Vancouver for congenital dislocation of the hip," Canadian Medical Association Journal, vol. 124, no. 8, pp. 1003-1008, 1981.

[149] J. Tijmes, L. Q. Garrido, S. F. Pasik, and B. Quintana, "Displasia de cadera. Pesquisa en la provincia de Llanquihue. (Hip dysplasia. Surgery in Llanquihue province)," Revista Chilena de Pediatria, vol. 42, pp. 633-639, 1971.

[150] J. R. Hazel and R. K. Beals, "Diagnosing dislocation of the hip in infancy," Western Journal of Medicine, vol. 151, no. 1, pp. 39-41, 1989.

[151] V.-P. Lehtola, The Sámi People: Traditions in Transition, University of Alaska Press, Fairbanks, Ark, USA, 2nd edition, 2004.

[152] K. Johnsen, R. Goll, and O. Reikerås, "Acetabular dysplasia in the Sami population: a population study among Sami in north Norway," International Journal of Circumpolar Health, vol. 67, no. 1, pp. 149-155, 2008.

[153] E. Lund, M. Brustad, and A. Høgmo, "The Sami - Living conditions and health," International Journal of Circumpolar Health, vol. 67, no. 1, pp. 6-8, 2008.

[154] J. C. Griffiths, "Dislocated hip in East African infants and children," Postgraduate Medical Journal, vol. 46, no. 532, pp. 86-91, 1970.

[155] B. Omololu, S. O. Ogunlade, and T. O. Alonge, "Pattern of congenital orthopaedic malformations in an African teaching hospital," West African Journal of Medicine, vol. 24, no. 2, pp. 92-95, 2005.

[156] A. P. Skirving and W. J. Scadden, "The African neonatal hip and its immunity from congenital dislocation," Journal of Bone and Joint Surgery, British, vol. 61, no. 3, pp. 339-341, 1979.

[157] M. Eidelman, A. Chezar, and V. Bialik, "Developmental dysplasia of the hip incidence in Ethiopian Jews revisited: 7Year prospective study," Journal of Pediatric Orthopaedics Part B, vol. 11, no. 4, pp. 290-292, 2002.

[158] J. Caffey, R. Ames, W. A. Silverman, C. T. Ryder, and G. Hough, "Contradiction of the congenital dysplasiapredislocation hypothesis of congenital dislocation of the hip through a study of the normal variation in acetabular angles at successive periods in infancy," Pediatrics, vol. 17, no. 5, pp. 632-641, 1956

[159] T. E. Reed, "Caucasian genes in American Negroes," Science, vol. 165, no. 3895, pp. 762-768, 1969.

[160] K. Palmén and S. Von Rosen, "Late diagnosis dislocation of the hip joint in children," Acta Orthopaedica Scandinavica, vol. 46, no. 1, pp. 90-101, 1975.

[161] H. V. Finlay, R. H. Maudsley, and P. I. Busfield, "Dislocatable hip and dislocated hip in the newborn infant," British Medical Journal, vol. 4, no. 516, pp. 377-381, 1967.

[162] R. Wynne-Davies, "A family study of neonatal and latediagnosis congenital dislocation of the hip," Journal of Medical Genetics, vol. 7, no. 4, pp. 315-333, 1970.

[163] S. Hay, "Incidence of selected congenital malformations in Iowa," American Journal of Epidemiology, vol. 94, no. 6, pp. 572-584, 1971.

[164] C. M. Woolf, J. H. Koehn, and S. S. Coleman, "Congenital hip disease in Utah: the influence of genetic and nongenetic factors," American Journal of Human Genetics, vol. 20, no. 5, pp. 430-439, 1968. 
[165] I. Leck and R. J. Lancashire, "Birth prevalence of malformations in members of different ethnic groups and in the offspring of matings between them, in Birmingham, England," Journal of Epidemiology and Community Health, vol. 49, no. 2, pp. 171-179, 1995.

[166] D. C. Robinson and P. J. De Buse, "Dislocatable hip in Ugandan newborn infants," East African Medical Journal, vol. 47, no. 7, pp. 395-397, 1970.

[167] R. H. Gross, M. Wismetske, T. C. Howard III, and M. Hitch, "Infant hip screening," in The Hip: Proceedings of the Tenth Open Scientific Meeting of the Hip Society, pp. 50-67, C. V. Mosby, St. Louis, Mo, USA, 1982.

[168] T. D. Artz, D. B. Levine, W. N. Lim, E. Salvati, and P. D. Wilson Jr., "Neonatal diagnosis, treatment and related factors of congenital dislocation of the hip," Clinical Orthopaedics and Related Research, vol. 110, pp. 112-136, 1975.

[169] M. Abdel-Kader and M. K. Booz, "Experience with congenital dislocation of the hip in Kuwait," Journal of Kuwait Medical Association, vol. 21, 1968.

[170] K. Al-Umran, A. A. H. Ahlberg Dawodu, M. I. El-Mouzan, and F. A. Ahmad, "Neonatal screening for hip instability: five years' experience," Annals of Saudi Medicine, vol. 8, no. 6, pp. 425-429, 1988.

[171] M. R. H. Khan and B. Benjamin, "Congenital hip instability in hospital born neonates in Abha," Annals of Saudi Medicine, vol. 12, no. 2, pp. 184-187, 1992.

[172] J. L. Hernández-Arriaga, G. Cortés-Gallo, C. AldanaValenzuela, and A. C. Ramirez-Huerta, "The incidence of external congenital malformations at the Hospital de Ginecopediatria no. 48 in León, Guanajuato," Boletín Médico del Hospital Infantil de México, vol. 48, pp. 717-721, 1991.

[173] Y. Morito, "Collagen amount in the umbilical cord in infants with unstable hip joint," Journal of the Japanese Orthopaedic Association, vol. 57, pp. 1859-1867, 1983.

[174] H.-T. Chen, "Congenital dysplasia of the hip in the new-born infants," College of Medicine, National Taiwan University, vol. 12, pp. 9-13, 1967.

[175] Y. Y. Hsieh, F. J. Tsai, C. C. Lin, F. C. C. Chang, and C. H. Tsai, "Breech deformation complex in neonates," Journal of Reproductive Medicine for the Obstetrician and Gynecologist, vol. 45, no. 11, pp. 933-935, 2000.

[176] L. Andrén, "Pelvic instability in newborns with special reference to congenital dislocation of the hip and hormonal factors. A roentgenologic study," Beitrage zur Orthopadie und Traumatologie, vol. 212, pp. 1-66, 1962.

[177] S. von Rosen, "Instability of the hip in the newborn. Fifteen years experience in Malmö," Acta Orthopaedica Scandinavica, vol. 130, Supplement, pp. 13-24, 1970.

[178] K. Palmén, "Preluxation of the hip joint. Diagnosis and treatment in the newborn and the diagnosis of congenital dislocation of the hip joint in Sweden during the years 19481960," Acta Paediatrica, vol. 50, supplement 129, pp. 6-71, 1961.

[179] T. Hinderaker, A. K. Daltveit, L. M. Ingens, A. Udén, and O. Reikerås, "The impact of intra-uterine factors on neonatal hip instability," Acta Orthopaedica Scandinavica, vol. 65, pp. 239-242, 1994.

[180] B. Almby and L. Rehnberg, "Neonatal hip instability. Incidence, diagnosis and treatment at the University Hospital, Uppsala, 1960-1964 and 1970-1974," Acta Orthopaedica Scandinavica, vol. 48, pp. 642-649, 1977.

[181] T. Hiertonn and U. James, "Congenital dislocation of the hip. Experiences of early diagnosis and treatment," Journal of Bone and Joint Surgery, British, vol. 50, no. 3, pp. 542-545, 1968.

[182] I. U. Medbö, "Early diagnosis and treatment of hip dysplasia," Acta Orthopaedica Scandinavica, vol. 31, pp. 282-315, 1961.

[183] K. B. Cyvín, "A follow-up study of children with instability of the hip joint at birth," Acta Orthopaedica Scandinavica, vol. 16, supplement, pp. 1-62, 1977.

[184] J. W. Dickson, "Pierre Le Damany on congenital dysplasia of the hip," Proceedings of the Royal Society of Medicine, vol. 62, no. 6, pp. 575-577, 1969.

[185] N. G. O'Brien and D. McGill, "Dislocatable hip in the newborn," Journal of the Irish Medical Association, vol. 63, no. 397, pp. 269-270, 1970.

[186] C. S. B. Galasko, S. Galley, and T. J. Menon, "Detection of congenital dislocation of the hip by an early screening program, with particular reference to false negatives," Israel Journal of Medical Sciences, vol. 16, no. 4, pp. 257-259, 1980.

[187] P. M. Dunn, R. M. Evans, M. J. Thearle, H. E. D. Griffiths, and P. J. Witherow, "Congenital dislocation of the hip: early and late diagnosis and management compared," Archives of Disease in Childhood, vol. 60, pp. 407-414, 1985.

[188] I. A. C. Lennox, J. McLauchlan, and R. Murali, "Failures of screening and management of congenital dislocation of the hip," Journal of Bone and Joint Surgery, British, vol. 75, no. 1, pp. 72-75, 1993.

[189] H. Drescher, "The relationship between presentation and congenital dislocation of the hip, with special reference to breech presentation,” Zentralblatt fur Gynäkologie, vol. 79, pp. 209-212, 1957.

[190] W. Szulc, "The frequency of occurrence of congenital dysplasia of the hip in Poland," Clinical Orthopaedics and Related Research, no. 272, pp. 100-102, 1991.

[191] L. I. Phillips, "Congenital dislocation of the hip in the newborn. A survey at National Women's Hospital 1954-68," New Zealand Medical Journal, vol. 68, no. 435, pp. 103-108, 1968.

[192] C. Bower, F. J. Stanley, B. Morgan, H. Slattery, and C. Stanton, "Screening for congenital dislocation of the hip by child-health nurses in Western Australia," Medical Journal of Australia, vol. 150, no. 2, pp. 61-65, 1989.

[193] J. Chaitow and D. Lillystone, "Congenital dislocation of the hip. Incidence, and treatment of a local population group," Medical Journal of Australia, vol. 140, no. 9, pp. 534-535, 1984.

[194] P. W. Goss, "Successful screening for neonatal hip instability in Australia," Journal of Paediatrics and Child Health, vol. 38, no. 5, pp. 469-474, 2002.

[195] S. S. Coleman, "Diagnosis of congenital dysplasia of the hip in the newborn infant," Journal of the American Medical Association, vol. 162, no. 6, pp. 548-554, 1956.

[196] I. V. Ponseti, "Morphology of the acetabulum in congenital dislocation of the hip. Gross, histological, and roentgenographic studies," Journal of Bone and Joint Surgery, American, vol. 60, no. 5, pp. 586-599, 1978.

[197] S. J. Tredwell and H. M. Bell, "Efficacy of neonatal hip examination," Journal of Pediatric Orthopaedics, vol. 1, no. 1, pp. 61-65, 1981.

[198] M. A. Ritter, "Congenital dislocation of the hip in the newborn," American Journal of Diseases of Children, vol. 125, no. 1, pp. 30-32, 1973.

[199] H. N. Ein, "Orthopaedic deformities in the newborn. A tenyear study at Newark Beth Israel Hospital," Journal of Newark Beth Israel Hospital, vol. 8, pp. 310-314, 1957. 
[200] S. Stanisavljevic, "Clinical findings in examination of hips in newborn babies," Henry Ford Hospital Medical Bulletin, vol. 10, pp. 245-252, 1962.

[201] S. L. Weissman and R. Salama, "Treatment of congenital dislocation of the hip in the newborn infant," Journal of Bone and Joint Surgery, British, vol. 51, no. 3, pp. 601-603, 1969.

[202] M. A. Klingberg, R. Chen, J. Chemke, and S. Levin, "Rising rates of congenital dislocation of the hip," The Lancet, vol. 1, no. 7954 , p. 298, 1976.

[203] N. Khrouf, R. Spång, T. Podgorna, S. B. Miled, M. Moussaoui, and M. Chivani, "Malformations in 10000 consecutive births in Tunis," Acta Paediatrica Scandinavica, vol. 75, pp. 534-539, 1986.

[204] V. Bialik and M. Berant, "Immunity" of Ethiopian Jews to developmental dysplasia of the hip: a preliminary sonographic study," Journal of Pediatric Orthopaedics Part B, vol. 6, no. 4, pp. 253-254, 1997.

[205] N. S. Tibrewala and P. M. Pai, "Congenital malformations in the newborn period," Indian Pediatrics, vol. 11, no. 6, pp. 403-407, 1974.

[206] H. Ferris, C. A. Ryan, and A. McGuinness, "Decline in the incidence of late diagnosed congenital dislocation of the hip," Irish Journal of Medical Science, vol. 166, no. 2, pp. 85-87, 1997.

[207] E. C. Lehmann, "Newborn screening for congenital dislocation of the hip in British Columbia," ONA Journal, vol. 4, no. 3, pp. 57-58, 1977.

[208] J. Poul, D. Garvie, R. Grahame, and A. J. S. Saunders, "Ultrasound examination of neonate's hip joints," Journal of Pediatric Orthopaedics Part B, vol. 7, no. 1, pp. 59-61, 1998.

[209] M. Treiber, T. Tomažič, A. Tekauc-Golob et al., "Ultrasound screening for developmental dysplasia of the hip in the newborn: a population -based study in the Maribor region, 1997-2005," Wiener Klinische Wochenschrift, vol. 120, pp. 3136, 2008.

[210] K. Rosendahl, T. Markestad, and R. T. Lie, "Developmental dysplasia of the hip: prevalence based on ultrasound diagnosis," Pediatric Radiology, vol. 26, no. 9, pp. 635-639, 1996.

[211] C. E. Bache, J. Clegg, and M. Herron, "Risk factors for developmental dysplasia of the hip: ultrasonographic findings in the neonatal period," Journal of Pediatric Orthopaedics Part B, vol. 11, no. 3, pp. 212-218, 2002.

[212] N. Szöke, L. Kuhl, and J. Heinrichs, "Ultrasound examination in the diagnosis of congenital hip dysplasia of newborns," Journal of Pediatric Orthopaedics, vol. 8, no. 1, pp. 12-16, 1988.

[213] D. Tönnis, K. Storch, and H. Ulbrich, "Results of newborn screening for $\mathrm{CDH}$ with and without sonography and correlation of risk factors," Journal of Pediatric Orthopaedics, vol. 10, no. 2, pp. 145-152, 1990.

[214] O. Rühmann, W. Konermann, D. Lazović, L. Vitek, and P. Bouklas, "Ultrasound screening in newborns: the influence of anamnestic risk factors to congenital dysplasia of the hip," Zeitschrift fur Orthopadie und Ihre Grenzgebiete, vol. 136, pp. 492-500, 1998.

[215] A. Partenheimer, M. Scheler-Hofmann, J. Lange et al., "Correlation between sex, intrauterine position and familial predisposition and neonatal hip ultrasound results," Ultraschall in der Medizin, vol. 27, no. 4, pp. 364-367, 2006.

[216] G. U. Exner, "Ultrasound screening for hip dysplasia in neonates," Journal of Pediatric Orthopaedics, vol. 8, no. 6, pp. 656-660, 1988.

[217] E. Peled, M. Eidelman, A. Katzman, and V. Bialik, "Neonatal incidence of hip dysplasia: ten years of experience," Clinical
Orthopaedics and Related Research, vol. 466, no. 4, pp. 771$775,2008$.

[218] G. Ballerini, A. Avanzini, T. Colombo, R. M. Crossignani, E. Micucci, and S. Santucci, "Ultrasound screening and follow-up of congenital hip dislocation. Literature review and personal experience in 1421 newborns," Radiologia Medica, vol. 80, no. 6, pp. 814-817, 1990.

[219] G. Riboni, S. Serantoni, M. de Simoni, P. Bascapè, R. Facchini, and G. Pirovano, "Ecografia dell'anca nell'epocs neonatala. 1507 casi," Radiologia Medica, vol. 81, p. 57, 1991.

[220] F. Franchin, G. Lacalendola, L. Molfetta, V. Vascolo, and L. Quagliarella, "Ultrasound for early diagnosis of hip dysplasia," Italian Journal of Orthopaedics and Traumatology, vol. 18, pp. 261-269, 1992.

[221] G. Riboni, A. Bellini, S. Serantoni, E. Rognoni, and L. Bisanti, "Ultrasound screening for developmental dysplasia of the hip," Pediatric Radiology, vol. 33, no. 7, pp. 475-481, 2003.

[222] E. A. Roovers, M. M. Moere-Boonekamp, T. S. A. Geertsma, G. A. Aielhuis, and A. H. M. Kerkhoff, "Ultrasonographic screening for developmental dysplasia of the hip in infants. Reprocucibility of assessments made by radiographers," Journal of Bone and Joint Surgery, British, vol. 85, pp. 726730, 2003.

[223] A. Akman, A. Korkmaz, M. C. Aksoy, M. Yazici, M. Yurdakök, and G. Tekinalp, "Evaluation of risk factors in developmental dysplasia of the hip: results of infantile hip ultrasonography," Turkish Journal of Pediatrics, vol. 49, no. 3, pp. 290-294, 2007.

[224] A. L. Chai and M. Sivanantham, "Congenital dislocation of hip in children: a review of patients treated in the Institute of Orthopaedics and Traumatology, General Hospital, Kuala Lumpur, 1975-1988," Medical Journal of Malaysia, vol. 45, no. 2, pp. 159-168, 1990.

[225] M. K. Kremli, A. H. Alshahid, K. I. Khoshhal, and M. M. Zamzam, "The pattern of developmental dysplasia of the hip," Saudi Medical Journal, vol. 24, no. 10, pp. 1118-1120, 2003.

[226] M. H. Mufti, "Prime factors in the etiology of congenital dislocation of the hip and talipes equinovarus in Riyadh," Annals of Saudi Medicine, vol. 8, no. 1, pp. 29-34, 1988.

[227] I. G. MacKenzie, H. J. Seddon, and D. Trevor, "Congenital dislocation of the hip," Journal of Bone and Joint Surgery, British, vol. 42, pp. 689-705, 1960.

[228] J. Wilkinson and C. Carter, "Congenital dislocation of the hip. The results of conservative treatment," Journal of Bone and Joint Surgery, British, vol. 42, pp. 669-688, 1960.

[229] D. G. Wray and B. N. Muddu, "Congenital dislocation of the hip. The high incidence of familial aetiology - a study of 130 cases," British Journal of Clinical Practice, vol. 37, no. 9, pp. 299-303, 1983.

[230] M. I. Romero, M. Julián, V. Gaete, P. Bedregal, J. I. Pinto, and C. Castiglione, "Epidemiologic characteristics of congenital hip dysplasia in a Chilean population," Revista Chilena de Pediatria, vol. 60, no. 5, pp. 268-271, 1989.

[231] G. W. Robinson, "Birth characteristics of children with cogenital dislocation of the hip," American Journal of Epidemiology, vol. 87, pp. 275-284, 1968.

[232] L. J. Paulozzi and J. M. Lary, "Laterality patterns in infants with external birth defects," Teratology, vol. 60, no. 5, pp. 265-271, 1999.

[233] F. S. Song, J. J. McCarthy, G. D. MacEwen, K. E. Fuchs, and S. E. Dulka, "The incidence of occult dysplasia of the contralateral hip in children with unilateral hip dysplasia," Journal of Pediatric Orthopaedics, vol. 28, no. 2, pp. 173-176, 2008. 
[234] C. C. Patterson, W. G. Kernohan, R. A. B. Mollan, P. E. Haugh, and B. P. Trainor, "High incidence of congenital dislocation of the hip in Northern Ireland," Paediatric Perinatal Epidemiology, vol. 9, pp. 90-97, 1995.

[235] C. O. Carter and J. A. Wilkinson, "Genetic and environmental factors in the etiology of congenital dislocation of the hip," Clinical Orthopaedics and Related Research, vol. 33, pp. 119$128,1964$.

[236] A. Tejavej and P. Siripoonya, "Breech presentation and the newborn hip," Journal of the Medical Association of Thailand, vol. 67, pp. 80-85, 1984.

[237] M. Luterkort, P. H. Persson, S. Polberger, and I. Bjerre, "Hip joint instability in breech pregnancy," Acta Paediatrica Scandinavica, vol. 75, no. 5, pp. 860-863, 1986.

[238] W. Hatzmann, B. Skowronek, H. Hoffken, A. Schroter, F. J. Schmitz, and W. Werner-Von-Der-Burg, "Hip sonography findings in newborn after intrauterine breech presentation," Ultraschall in der Medizin, vol. 14, no. 4, pp. 163-168, 1993.

[239] M. L. Padilla Esteban, A. N. Espert, A. C. de la Mano, and J. M. G.-S. Pardo, "Frequency of congenital dislocation of the hip in 40,243 live births (Part II)," Anales Espanoles de Pediatria, vol. 33, pp. 539-541, 1990.

[240] O. Kauppila, "The perinatal mortality in breech deliveries and observations of affecting factors," Acta Obstetricia et Gynecologica Scandinavica, vol. 39, supplement, pp. 1-39, 1975.

[241] J. Szepesi, A. Hattyár, and L. Molnár, "The effect of breech presentation on the development of the hip," Magyar Traumatológia, Ortopédia, Kézsebészet, Plasztikai Sebészet, vol. 36, pp. 11-15, 1993.

[242] O. Rühmann, D. Lazović, P. Bouklas, F. Gossé, and J. Franke, "Ultrasound screening of neonatal hip. Correlation of anamnestic risk factors and congenital dysplasia," Klinische Padiatrie, vol. 211, pp. 141-148, 1999.

[243] A. F. Díaz, L. S. Navas, and R. A. Viladrich, "Obstetrical and perinatal risk factors for congenital dislocation of the hip," Anales Espanoles de Pediatria, vol. 46, pp. 29-32, 1997.

[244] J. E. Andersson and A. Odén, “The breech presentation and the vertex presentation following an external version represent risk factors for neonatal hip instability," Acta Paediatrica, vol. 90, no. 8, pp. 895-898, 2001.

[245] K. J. Holen, A. Tegnander, T. Tergesen, O. J. Johansen, and S. H. Eik-Nes, "Ultrasonographic evaluation of breech presentation as a risk factor for hip dysplasia," Acta Paeditrica, vol. 85, pp. 225-229, 1996.

[246] C. A. Lowry, V. B. Donoghue, C. O’Herlihy, and J. F. Murphy, "Elective Caesarean section is associted with a reduction in developmental dysplasia of the hip in term breech infants," Journal of Bone and Joint Surgery, British, vol. 87, no. 7, pp. 984-985, 2005.

[247] P. Lapunzina, J. S. L. Camelo, M. Rittler, and E. E. Castilla, "Risks of congenital anomalies in large for gestational age infants," Journal of Pediatrics, vol. 140, no. 2, pp. 200-204, 2002.

[248] U. von Deimling, J. M. Brähler, M. Niesen, U. A. Wagner, and J. Walpert, "Effect of birth weight on hip maturation in the newborn infant," Klinische Padiatrie, vol. 210, pp. 115-119, 1998.

[249] M. Amato, R. Claus, and P. Huppi, "Perinatal hip assessment in very low birth weight infants," Pediatric Radiology, vol. 22, no. 5, pp. 361-362, 1992.

[250] F. T. Hoaglund and J. H. Healey, "Osteoarthrosis and congenital dysplasia of the hip in family members of children who have congenital dysplasia of the hip," Journal of Bone and Joint Surgery, American, vol. 72, no. 10, pp. 1510-1518, 1990.

[251] S. S. Hanflig, "Familial congenital dislocation of the hip," The New England Journal of Medicine, vol. 209, pp. 545-547, 1933.

[252] K. Tsuchiya, T. Suzuki, S. Okuyama et al., "Genetic study on congenital dislocation of the hip," Journal of the Japanese Orthopedic Association, vol. 33, pp. 864-879, 1959.

[253] K. Rybak, D. Zwierzchowska, and H. Zwieerzchowski, "Familial occurrence of congenital hip dislocation," Chirurgie Narzadow Ruchu i Ortopedia Polska, vol. 49, pp. 545-547, 1984.

[254] A. Czeizel, J. Szentpetery, G. Tusnady, and T. Vizkelety, "Two family studies on congenital dislocation of the hip after early orthopaedic screening in Hungary," Journal of Medical Genetics, vol. 12, no. 2, pp. 125-130, 1975.

[255] M. Atasu, Ü. Akkoyunlu, N. Tokgozoglu, and B. Say, "The heritability of liability to congenital dislocation of the hip," Turkish Journal of Pediatrics, vol. 14, no. 1, pp. 23-26, 1972.

[256] R. K. Beals, "Familial primary acetabular dysplasia and dislocation of the hip," Clinical Orthopaedics and Related Research, no. 406, pp. 109-115, 2003.

[257] I. Alkalay and J. Shmuel, "Detection and treatment of congenital dislocation of the hip in 'babies at risk' in Western Galillee," British Journal of Clinical Practice, vol. 42, no. 12, pp. 495-497, 1988.

[258] C. Stein-Zamir, I. Volovik, S. Rishpon, and R. Sabi, "Developmental dysplasia of the hip: risk markers, clinical screening and outcome," Pediatrics International, vol. 50, no. 3, pp. 341-345, 2008.

[259] A. Gunther, S. J. Smith, P. V. Maynard, M. W. Beaver, and C. E. D. Chilvers, "A case-control study of congenital hip dislocation," Public Health, vol. 107, no. 1, pp. 9-18, 1993.

[260] D. W. Smith and J. M. Aase, "Polygenic inheritance of certain common malformations. Evidence and empiric recurrence risk data," The Journal of Pediatrics, vol. 76, no. 5, pp. 653659, 1970.

[261] A. A. Kramer, K. Berg, and W. E. Nance, "Familial aggregation of congenital dislocation of the hip in a Norwegian population," Journal of Clinical Epidemiology, vol. 41, no. 1, pp. 91-96, 1988.

[262] W. Cui, C. X. Ma, Y. Tang et al., "Sex differences in birth defects: a study of opposite-sex twins," Birth Defects Research Part A, vol. 73, no. 11, pp. 876-880, 2005.

[263] K. Hale, "Some biologic evidence obtained from a study of congenital dislocation of hips in identical twins supporting the developmental theory," Annals of Surgery, vol. 83, pp. 682-685, 1926.

[264] M. Geiser and P. Buri, "Congenital dislocation of the hip in identical twins," Journal of Bone and Joint Surgery, British, vol. 41, no. 2, pp. 314-318, 1959.

[265] G. Ceylaner, S. Ceylaner, F. Ustunkan, and M. Inan, "Autosomal dominant inheritance of congenital dislocation of the hip in 16 members of a family," Acta Orthopaedica et Traumatologica Turcica, vol. 42, pp. 289-291, 2008.

[266] R. Wynne-Davies, "Acetabular dysplasia and familial joint laxity: two etiological factors in congenital dislocation of the hip. A review of 589 patients and their families," Journal of Bone and Joint Surgery, British, vol. 52, no. 4, pp. 704-716, 1970.

[267] A. Czéizel, G. Tusnády, G. Vaczó, and T. Vozkelety, “The mechanism of genetic prediposition in congenital dislocation of the hip," Journal of Medical Genetics, vol. 12, pp. 121-124, 1975. 
[268] V. Sollazzo, G. Bertolani, E. Calzolari, G. Atti, and C. Scapoli, "A two-locus model for non-syndromic congenital dysplasia of the hip (CDH)," Annals of Human Genetics, vol. 64, no. 1, pp. 51-59, 2000.

[269] S. Cvjeticanin and D. Marinkovic, "Genetic variability in the group of patients with congenital hip dislocation," Genetika, vol. 41, no. 8, pp. 1142-1146, 2005.

[270] J. Zervas, H. Zouboupoulos, C. Constantopoulos, S. D. Theodorou, M. Toubis, and P. Fessas, "HLA antigens and congenital dislocation of the hip," Tissue Antigens, vol. 22, pp. 295-297, 1983.

[271] C. Dostál, S. Popelka, E. Ivašková, H. Macurová, and J. Zvárová, "First class HLA factors $(\mathrm{A}, \mathrm{B}, \mathrm{C}$,) in congenital hip joints dysplasia (CHJD)," Tissue Antigens, vol. 26, no. 4, pp. 266-268, 1985.

[272] T. Torisu, Y. Fujikawa, H. Yano, and S. Masumi, "Association of HLA-DR and HLA-DQ antigens with congenital dislocation and dysplastic osteoarthritis of the hip joints in Japanes people," Arthritis and Rheumatism, vol. 36, pp. 815818, 1993.

[273] I. I. Taboridze, L. T. Aladashvili, and E. F. Lordkipanidze, "Association of the ABO blood group system and hip joint dysplasia," Ortopediia Travmatologiia i Protezirovanie, vol. 8, pp. 23-26, 1991.

[274] J. Dai, D. Shi, P. Zhu et al., "Association of a single nucleotide polymorphism in growth differentiate factor 5 with congenital dysplasia of the hip: a case-control study," Arthritis Research and Therapy, vol. 10, no. 5, article R126, 2008.

[275] L. Zhu, D. Shi, J. Dai et al., "Lack of evidence for association between DVWA gene polymorphisms and developmental dysplasia of the hip in Chinese Han population," Rheumatology International, vol. 31, no. 7, pp. 883-887, 2010.

[276] B. Kapoor, C. Dunlop, C. Wynn-Jones, A. A. Fryer, R. C. Strange, and N. Maffulli, "Vitamin D and oestrogen receptor polymorphisms in developmental dypslasia of the hip and primary protrusio acetabuli - a preliminary report," Journal of Negative Results in BioMedicine, vol. 6, p. 7, 2007.

[277] G. Feldman, C. Dalsey, K. Fertala et al., "The otto aufranc award: identification of a $4 \mathrm{Mb}$ region on chromosome 17q21 linked to developmental dysplasia of the hip in one 18member, multigeneration family," Clinical Orthopaedics and Related Research, vol. 468, no. 2, pp. 337-344, 2010.

[278] J. Jiang, H. W. Ma, Y. Lu et al., “Transmission disequilibrium test for congenital dislocation of the hip and HOXB9 gene or COL1AI gene," Chinese Journal of Medical Genetics, vol. 20, no. 3, pp. 193-195, 2003.

[279] D. Granchi, S. Stea, A. Sudanese, A. Toni, N. Baldini, and A. Giunti, "Association of two gene polymorphisms with osteoarthritis secondary to hip dysplasia," Clinical Orthopaedics and Related Research, no. 403, pp. 108-117, 2002.

[280] M. Rubini, A. Cavallaro, E. Calzolari, G. Bighetti, and V. Sollazzo, "Exclusion of COL2A1 and VDR as developmental dysplasia of the hip genes," Clinical Orthopaedics and Related Research, vol. 466, no. 4, pp. 878-883, 2008.

[281] A. J. Carr, R. J. Jefferson, and M. K. Benson D’A. M.K., "Joint laxity and hip rotation in normal children and in those with congenital dislocation of the hip," Journal of Bone and Joint Surgery, British, vol. 75, no. 1, pp. 76-78, 1993.

[282] C. Carter and J. Wilkinson, "Persistent joint laxity and congenital dislocation of the hip," Journal of Bone and Joint Surgery, British, vol. 46, pp. 40-45, 1964.
[283] N. Fredensborg, "Observations in children with congenital dislocation of the hp," Acta Orthopaedica Scandinavica, vol. 47, pp. 175-180, 1976.

[284] A. Üden and T. Lindhagen, "Inguinal hernia in patients with congenital dislocation of the hip. A sign of general connective tissue disorder," Acta Orthopaedica Scandinavica, vol. 59, pp. 667-668, 1988.

[285] N. Fredensborg and A. Uden, "Altered connective tissue in children with congenital dislocation of the hip," Archives of Disease in Childhood, vol. 51, no. 11, pp. 887-889, 1976.

[286] B. A. Jensen, I. Relmann, and N. Fredensborg, "Collagen type III predominance in newborns with congenital dislocation of the hip," Acta Orthopaedica Scandinavica, vol. 57, pp. 362365, 1986.

[287] A. P. Skirving, T. J. Sims, and A. J. Bailey, "Congenital dislocation of the hip: a possible inborn error of collagen metabolism," Journal of Inherited Metabolic Disease, vol. 7, pp. 27-31, 1984.

[288] H. Oda, M. Igarashi, Y. Hayashi et al., "Soft tissue collagen in congenital dislocation of the hip - biochemical studies of the ligamentum teres of the femur and hip joint capsule," Journal of the Japanese Orthopaedic Association, vol. 58, pp. 331-338, 1984.

[289] S. Sarban, F. Baba, Y. Kocabey, M. Cengiz, and U. E. Isikan, "Free nerve endings and morphological features of the ligamentum capitis femoris in developmental dysplasia of the hip," Journal of Pediatric Orthopaedics Part B, vol. 16, no. 5, pp. 351-356, 2007.

[290] C. W. Denko and B. Boja, "Growth hormone, insulin, and insulin-like growth factor-1 in hypermobility syndrome," Journal of Rheumatology, vol. 28, no. 7, pp. 1666-1669, 2001.

[291] L. Andrén and N. E. Borglin, "A disorder of oestrogen metabolism as a causal factor of congenital dislocation of the hip," Acta Orthopaedica Scandinavica, vol. 30, pp. 169-171, 1961.

[292] L. Andrén and N. E. Borglin, "Disturbed urinary excretion pattern of oestrogens in newborns with congenital dislocation of the hip. I. The excretion of oestrogen during the first few days of life," Acta Endocrinolgica, vol. 37, p. 3, 1961.

[293] L. Andrén and N. E. Borglin, "Disturbed urinary excretion pattern of oestrogens in newborns with congenital dislocation of the hip. II. The excretion of exogenous oestradiol17ß," Acta Endocrinolgica, vol. 37, pp. 427-433, 1961.

[294] W. S. Smith, O. Lieberg, and U. Goebelsmann, "Estrogen determinations in a pregnant woman with a family history of congenital dislocation of the hip. A case report," Clinical Orthopaedics and Related Research, vol. 88, pp. 56-59, 1972.

[295] D. Aarskog, K. F. Stoa, and T. Thorsen, "Urinary oestrogen excretion in newborn infants with congenital dysplasia of the hip joint," Acta Paediatrica Scandinavica, vol. 55, no. 4, pp. 394-397, 1966.

[296] W. T. Thieme, R. Wynne-Davies, H. A. F. Blair, E. T. Bell, and J. A. Loraine, "Clinical exmaination and urinary oestrogen assays in newborn children with congenital dislocation of the hip," Journal of Bone and Joint Surgery, British, vol. 50, pp. 546-550, 1968.

[297] N. E. Borglin, "Excretion ofo oestriol in the urine in newborn boys and girls in cases of congenital dislocation of the hip," Acta Endocrinologica, vol. 37, pp. 511-515, 1961.

[298] J. E. Andersson, I. Vogel, and N. Uldbjerg, "Serum $17 \beta$ estradiol in newborn and neonatal hip instability," Journal of Pediatric Orthopaedics, vol. 22, no. 1, pp. 88-91, 2002.

[299] L. F. Saugstad, "Is persistent pelvic pain and pelvic joint instability associated with early menarche and with oral 
contraceptives?" European Journal of Obstetrics Gynecology and Reproductive Biology, vol. 41, no. 3, pp. 203-206, 1991.

[300] A. H. MacLennan and S. C. MacLennan, "Symptom-giving pelvic girdle relazation of pregnancy, postnatal pelvic joint syndrome and developmental dysplasia of the hip," Acta Obstetricia et Gynecologica Scandinavica, vol. 76, pp. 760764, 1997.

[301] A. H. MacLennan, R. Nicolson, R. C. Green, and M. Bath, "Serum relaxin and pelvic pain of pregnancy," The Lancet, vol. 2, no. 8501, pp. 243-246, 1986.

[302] A. Hansen, D. V. Jensen, E. Larsen, C. Wilken-Jensen, and L. K. Petersen, "Relaxin is not related to symptom-giving pelvic girdle relaxation in pregnant women," Acta Obstetricia et Gynecologica Scandinavica, vol. 75, pp. 245-249, 1996.

[303] L. K. Petersen, L. Hvidman, and N. Uldbjerg, "Normal serum relaxin in women with disabling pelvic pain during pregnancy," Gynecologic and Obstetric Investigation, vol. 38, pp. 21-23, 1994.

[304] I. Vogel, J. E. Andersson, and N. Uldjberg, "Serum relaxin in the newborn is not a marker of neonatal hip instability," Journal of Pediatric Orthopaedics, vol. 18, pp. 535-537, 1998.

[305] J. Forst, C. Forst, R. Forst, and K. D. Heller, "Pathogenetic relevance of the pregnancy hormone relaxin to inborn hip instability," Archives of Orthopaedic and Trauma Surgery, vol. 116, no. 4, pp. 209-212, 1997.

[306] B. M. Obermayer-Pietsch, D. Walter, S. Kotschan, M. Freigassner-Pritz, R. Windhager, and G. Leb, “Congenital hip dysplasia and bone mineral density of the hip—a new risk factor for osteoporotic fracture?" Journal of Bone and Mineral Research, vol. 15, no. 9, pp. 1678-1682, 2000.

[307] A. Gębala, A. Jablońska, H. Iwanowski, and I. Wośko, “Serum calcium, inorganic phosphorus and alkaline phosphotase levels in children with congenital hip luxation," Pediatria Polska, vol. 45, pp. 393-397, 1970.

[308] S. Nagura, "The aetiology of congenital dislocation of the hip," Zentralblatt fur Chirurgie, vol. 80, pp. 1933-1940, 1955.

[309] M. Watanabe, A. Saito, and K. Takeda, "Incidence of congenital dislocation of the hip $(\mathrm{CDH})$ before and after preventive management-an analysis from newborn $\mathrm{CDH}$ and late diagnosed cases," in Prevention of Congenital Dislocation of the Hip in Infants: Experience and Results in Japan, M. Ando, Ed., pp. 19-23, Yamada Company, Asahikawa, Japan, 1993.

[310] L. Andrén and K. Palmén, "Seasonal variation of birth dates of infants with congenital dislocation of the hip," Acta Orthopaedica Scandinavica, vol. 33, pp. 127-131, 1963.

[311] M. Gladisch and R. Scippan, "Seasonal distribution of dysplasia of the hip," Bietrage zur Orthopadie und Traumatologie, vol. 11, pp. 300-303, 1964.

[312] P. Uibe, "Seasonal influences on incidence of hip luxations," Zentralblatt für Chirurgie, vol. 84, pp. 237-240, 1959.

[313] P. Schmidt-Peter, "Noch einmal: einfluß der jahreszeiten auf die häufigkeit der luxationshüfte," Beitrage zur Orthopadie und Truamatologie, vol. 9, pp. 32-34, 1962.

[314] B. C. Slater, G. I. Watson, and J. C. McDonald, "Seasonal variation in congenital abnormalities. Preliminary report of a survey conducted by the Research Committee of Council of the College of General Practitioners," British Journal of Preventive \& Social Medicine, vol. 18, pp. 1-7, 1964.

[315] J. H. Edwards, "Seasonal incidence of congenital disease in Birmingham," Annals of Human Genetics, vol. 25, pp. 89-93, 1961.
[316] R. Chen, S. L. Weissman, R. Salama, and M. A. Klingberg, "Congenital dislocation of the hip $(\mathrm{CDH})$ and seasonality: the gestational age of vulnerability to some seasonal factor," American Journal of Epidemiology, vol. 92, no. 5, pp. 287-293, 1970.

[317] J. K. Anand, I. Moden, and J. W. Myles, "Incidence of neonatal hip instability: are there seasonal variations?" Acta Orthopaedica Belgica, vol. 58, no. 2, pp. 205-208, 1992.

[318] P. Cohen, "Seasonal variation of congenital dislocation of the hip," Journal of Interdisciplinary Cycle Research, vol. 2, pp. 417-425, 1971.

[319] P. J. Charlton, "Seasonal variation in incidence of some congenital malformations in two Australian samples," Medical Journal of Australia, vol. 2, no. 18, pp. 833-835, 1966.

[320] H. Mizuno, A. Ito, I. Hotta et al., "Influences of birth-season on development of the infant hip-joint," Journal of Nagoya Medical Association, vol. 84, pp. 632-641, 1961.

[321] D. Berezin, "Pelvic insufficiency during pregnancy and after paturition," Acta Obstetricia et Gynecologica Scandinavica, vol. 33, supplement 3, pp. 1-130, 1953.

[322] C. Siffel, C. J. Alverson, and A. Correa, "Analysis of seasonal variation of birth defects in Atlanta," Birth Defects Research Part A, vol. 73, no. 10, pp. 655-662, 2005.

[323] E. L. Lipton, A. Steinschneider, and J. B. Richmond, "Swaddling, a child care practice: historical, cultural, and experimental observations," Pediatrics, vol. 35, pp. 519-567, 1965.

[324] A. W. Eriksson, W. Lehmann, and N. E. Simpson, "Genetic studies on circumpolar populations," in The Human Biology of Circumpolar Populations, F. A. Milan, Ed., pp. 81-168, Cambridge University Press, Cambridge, UK, 1980.

[325] Y. Yamada, "Prophylaxis of congenital dislocation of the hip at Tokoname city," in Prevention of Congenital Dislocation of the Hip in Infants: Experience and Results in Japan, M. Ando, Ed., pp. 27-30, Yamada Company, Asahikawa, Japan, 1993.

[326] M. A. El-Kader Shaheen, "Mehad: the Saudi tradition of infant wrapping as a possible aetiological factor in congenital dislocation of the hip," Journal of the Royal College of Surgeons of Edinburgh, vol. 34, no. 2, pp. 85-87, 1989.

[327] A. Ghibely, "Congenital dislocation of the hip in the Cree Indian population of Quebec, Canada," Acta Orthopaedica Belgica, vol. 56, no. 1 A, pp. 37-42, 1990.

[328] M. W. Chaarani, M. S. Al Mahmeid, and A. M. Salman, "Developmental Dysplasia of the Hip before and after increasing community awareness of the harmful effects of swaddling," Qatar Medical Journal, vol. 11, no. 1, pp. 40-43, 2002.

[329] M. Abu-Nawarig, "Congenital dysplasia of hip in Eastern Province of Saudi Arabia," Orthopaedic Review, vol. 10, no. 12, pp. 35-39, 1981.

[330] A. Bloch, "The Kurdistani cradle story. A modern analysis of this centuries-old infant swaddling practice," Clinical Pediatrics, vol. 5, no. 10, pp. 641-645, 1966.

[331] P. Holck, "The occurrence of hip joint dislocation in early Lappic populations of Norway," International Journal of Osteoarchaeology, vol. 1, pp. 199-202, 1991.

[332] M. Janeček, "Congenital hip dislocation in children in Northern Korea," Acta Chirurgiae Orthopaedicae et Traumatologiae Cechoslovaca, vol. 23, pp. 2-5, 1956.

[333] J. R. Corea, "Is congenital dislocation of the hip rare in Sri Lanka?” The Ceylon Medical Journal, vol. 37, no. 3, p. 96, 1992.

[334] Society for Applied Anthropology in Manitoba, "Summary of SAAM Presentations,” Anthropology in Practice, 2001:1. 
[335] M. Ando, Prevention of Congenital Dislocation of the Hip in Infants: Experience and Results in Japan, Yamada Company, Asahikawa, Japan, 1993.

[336] S. T. Mahan and J. R. Kasser, "Does swaddling influence developmental dysplasia of the hip?" Pediatrics, vol. 121, no. 1, pp. 177-178, 2008.

[337] M. A. Smith, "Swaddling and congenital dislocation of the hip," British Medical Journal, vol. 2, no. 6136, p. 569, 1978.

[338] B. E. Van Sleuwen, A. C. Engelberts, M. M. BoereBoonekamp, W. Kuis, T. W. J. Schulpen, and M. P. L'Hoir, "Swaddling: a systematic review," Pediatrics, vol. 120, no. 4, pp. e1097-e1106, 2007.

[339] L. Owen, "Swaddling and CDH," Pediatric Nursing, vol. 9, no. 2, p. 143, 1983.

[340] H. N. Karp, "Safe swaddling and healthy hips: don't toss the baby out with the bathwater," Pediatrics, vol. 121, no. 5, pp. 1075-1076, 2008.

[341] D. P. Gywnne Jones, J. D. Dunbar, and J.-C. Theis, "Late presenting dislocation of sonographically stable hips," Journal of Pediatric Orthopaedics B, vol. 15, pp. 257-261, 2006.

[342] A. Raimann, A. Baar, R. Raimann, and J. A. Morcuende, "Late developmental dislocation of the hip after initial normal evaluation: a report of five cases," Journal of Pediatric Orthopaedics, vol. 27, no. 1, pp. 32-36, 2007.

[343] S. J. M. Davies and G. Walker, "Problems in the early recognition of hip dysplasia," Journal of Bone and Joint Surgery, British, vol. 66, no. 4, pp. 479-484, 1984.

[344] A. B. Gill, "Congenital dislocation of the hip," Journal of Bone and Joint Surgery, American, vol. 30, pp. 526-527, 1948.

[345] S. J. Gillam, M. Foss, and M. Woolaway, "Late presentation of congenital dislocation of the hip: an audit," The British Journal of General Practice, vol. 40, no. 335, pp. 236-237, 1990.

[346] J. F. Haasbeek, J. G. Wright, and D. M. Hedden, "Is there a difference between the epidemiologic characteristics of hip dislocation diagnosed early and late?" Canadian Journal of Surgery, vol. 38, no. 5, pp. 437-438, 1995.

[347] I. Bjerkreim and J. Johansen, "Late diagnosed congenital dislocation of the hip," Acta Orthopaedica Scandinavica, vol. 58, pp. 504-506, 1987.

[348] E. Heikkilä, S. Ryöppy, and I. Louhimo, "Late diagnosis of congenital dislocation of the hip," Acta Orthopaedica Scandinavica, vol. 55, pp. 526-560, 1984.

[349] S. Kamath, A. Mehdi, N. Wilson, and R. Duncan, "The lack of evidence of the effect of selective ultrasound screening on the incidence of late developmental dysplasia of the hip in the Greater Glasgow Region," Journal of Pediatric Orthopaedics Part B, vol. 16, no. 3, pp. 189-191, 2007.

[350] T. Hinderaker and O. Reikerås, "Late diagnosis of congenital hip dislocation in northern Norway," Acta Orthopaedica Scandinavica, vol. 58, p. 340, 1987.

[351] H. Z. Herold, "Unilateral congenital hip dislocation with contralateral avascular necrosis," Clinical Orthopaedics and Related Research, vol. 148, pp. 196-202, 1980.

[352] Z. Katz, M. Lancet, J. Skornik, J. Chemke, B. M. Mogilner, and M. Klinberg, "Teratogenicity of progestogens given during the first trimester of pregnancy," Obstetrics and Gynecology, vol. 65, pp. 775-780, 1985.

[353] N. Ishikawa, "The relationship between neonatal developmental dysplasia of the hip and maternal hypothyroidism," Journal of Pediatric Orthopaedics, vol. 28, pp. 432-434, 2008.

[354] R. E. Stevenson and C. C. Huntley, "Congenital malformations in offspring of phenylketonuric mothers," Pediatrics, vol. 40, no. 1, pp. 33-45, 1967.
[355] E. Chasiotis-Tourikis, A. Varvarigou, S. Yarmenitis, N. Vandoros, and N. G. Beratis, "Maternal smoking during pregnancy improves the anatomy of the hip joint in the female neonate," Journal of Maternal-Fetal and Neonatal Medicine, vol. 14, no. 1, pp. 45-50, 2003.

[356] J. V. Neel, "A study of major congenital defects in Japanese infants," American Journal of Human Genetics, vol. 10, pp. 394-445, 1958.

[357] P. Mastroiacovo, A. Spagnola, E. Marri, L. Meazza, R. Bertolini, and G. Segni, "Birth defects in the Seveso area after TCDD contamination," Journal of the American Medical Association, vol. 259, pp. 1668-1672, 1988.

[358] Z. Haicl, J. Jíra, E, Petŕíková, and V. Bozdêch, "Results of the diagnostic test for toxoplasmosis in relation to the congenital dislocation of the hip joint," Acta Chirurgiae Orthopaedicae et Traumatologiae Cechoslovaca, vol. 33, pp. 504-509, 1966.

[359] M. Aksoy, S. Erdem, and K. Dinçol, "Iron deficiency anemia as a possible contributory factor in the development of dislocation of the hip," Blut, vol. 15, pp. 153-156, 1967.

[360] R. J. Bielski, M. W. Gesell, A. L. Teng, D. H. Cooper, and J. K. Muraskas, "Orthopaedic implications of multiple gestation pregnancy with triplets," Journal of Pediatric Orthopaedics, vol. 26, no. 1, pp. 129-131, 2006.

[361] A. Sionek, J. Czubak, K. Kornacka, and B. Grabowski, "Evaluation of risk factors in developmental dysplasia of the hip in children from multiple pregnancies: results of hip ultrasonography using Graf's method," Ortopedia Traumatologia Rehabilitacja, vol. 10, pp. 115-130, 2008.

[362] O. Rühmann, D. Lazović, P. Bouklas, S. Schmolke, and C. H. Flamme, "Ultrasound examination of neonatal hip: correlation of twin pregnancy and congenital dysplasia," Twin Research, vol. 3, no. 1, pp. 7-11, 2000.

[363] M. A. Campana and M. M. Roubicek, "Maternal and neonatal variables in twins: an epidemiological approach," Acta Geneticae Medicae et Gemellologiae, vol. 45, pp. 461-469, 1996.

[364] P. Mastroiacovo, E. E. Castilla, C. Arpino et al., "Congenital malformations in twins: an international study," American Journal of Medical Genetics, vol. 83, no. 2, pp. 117-124, 1999.

[365] M. de Pellegrin, D. Fracassetti, A. Terenghi, and D. Spagnolo, "Congenital dysplasia of the hip in twins. Ultrasound evaluation," Rivista Italiana di Pediatria, vol. 20, pp. 704-706, 1994.

[366] O. Rühmann, D. Lazović, P. Bouklas, and S. Rössig, "Ultrasound screening of neonatal hip. Is twin pregnancy a risk factor for congenital dysplasia?" Ultraschall in der Medizin, vol. 19, no. 2, pp. 64-69, 1998.

[367] H. J. Witt, H. Weickert, H. Merk, and J. P. Woltersdorf, "Studies of hip dislocation in twins," Beitrage zur Orthopadie und Traumatologie, vol. 36, pp. 259-263, 1989.

[368] N. C. Myrianthopoulos, "Congenital malformations in twin: epidemiologic survey," Birth Defects Original Article Series, vol. 11 , no. 8 , p. $27,1975$.

[369] K. Kato and K. Fujiki, "Multiple births and congenital anomalies in Tokyo metropolitan hospitals, 1797-1990," Acta Geneticae Medicae et Gemellologiae, vol. 41, pp. 253-259, 1992.

[370] S. J. Li, N. Ford, K. Meister, and J. Bodurtha, "Increased risk of birth defects among children from multiple births," Birth Defects Research Part A, vol. 67, no. 10, pp. 879-885, 2003.

[371] P. E. Doyle, V. Beral, B. Botting, and C. J. Wale, "Congenital malformations in twins in England and Wales," Journal of Epidemiology and Community Health, vol. 45, pp. 43-48, 1990. 
[372] M. G. Uglow and N. M. P. Clarke, "Congenital dislocation of the hip in extrauterine pregnancy," Journal of Bone and Joint Surgery, British, vol. 78, no. 5, pp. 751-753, 1996.

[373] R. Kohler, "Congenital dislocation of the hip in extrauterine pregnancy," Journal of Bone and Joint Surgery, British, vol. 79, no. 2, p. 343, 1997.

[374] J. Jarcho, "Ectopic pregnancy. II. With special reference to abdominal pregnancy," The American Journal of Surgery, vol. 77, no. 4, pp. 423-455, 1949.

[375] N. J. Wald, E. Terzian, P. A. Vickers, and J. A. C. Weatherall, "Congenital talipes and hip malformation in relation to amniocentesis: a case-control study," The Lancet, vol. 2, no. 8344, pp. 246-249, 1983.

[376] M. Cederholm, B. Haglund, and O. Axelsson, "Infant morbidity following amniocentesis and chorionic villus sampling for prenatal karyotyping," BJOG, vol. 112, no. 4, pp. 394-402, 2005.

[377] P. Jouppila and M. Koivisto, "The prognosis in pregnancy after threatened abortion," Annales Chirurgiae et Gynaecologiae, vol. 63, no. 6, pp. 439-444, 1974.

[378] J. E. Paz, L. Otaño, E. C. Gadow, and E. E. Castilla, "Previous miscarriage and stillbirth as risk factors for other unfavorable outcomes in the next pregnancy," British Journal of Obstetrics and Gynaecology, vol. 99, pp. 808-812, 1992.

[379] S. Simić, Z. Vukašinović, J. Samardžić et al., "Does the gestation age of newborn babies influence the ultrasonic assessment of hip condition?" Srpski Arhiv Za Celokupno Lekarstvo, vol. 137, no. 7-8, pp. 402-408, 2009.

[380] U. Bick, C. Muller-Leisse, and J. Troger, "Ultrasonography of the hip in preterm neonates," Pediatric Radiology, vol. 20, no. 5, pp. 331-333, 1990.

[381] T. Timmler, M. Wierusz-Kozłowska, J. Markuszewski, and W. Woźniak, "The hip joints of preterm neonates in sonographic evaluation," Chirurgia Narzadow Ruchu i Ortopedia Polska, vol. 70, no. 4, pp. 301-305, 2005.

[382] A. Ali-Gombe, P. R. Croft, and A. J. Silman, "Osteoarthritis of the hip and acetabular dysplasia in Nigerian men," Journal of Rheumatology, vol. 23, no. 3, pp. 512-515, 1996.

[383] B. C. Msamati, P. S. Igbigbi, and C. B. D. Lavy, "Geometric measurements of the acetabulum in adult Malawians: radiographic study," East African Medical Journal, vol. 80, no. 10, pp. 546-549, 2003.

[384] A. P. Skirving, "The centre-edge angle of Wiberg in adult Africans and Caucasians. A radiographic comparison," Journal of Bone and Joint Surgery, vol. 63, no. 4, pp. 567-568, 1981.

[385] N. Yoshimura, L. Campbell, T. Hashimoto et al., "Acetabular dysplasia and hip osteoarthritis in Britain and Japan," British Journal of Rheumatology, vol. 37, no. 11, pp. 1193-1197, 1998.

[386] P. Croft, C. Cooper, C. Wickham, and D. Coggon, "Osteoarthritis of the hip and acetabular dysplasia," Annals of the Rheumatic Diseases, vol. 50, no. 5, pp. 308-310, 1991.

[387] R. W. Smith, P. Egger, D. Coggon, M. I. D. Cawley, and C. Cooper, "Osteoarthritis of the hip joint and acetabular dysplasia in women," Annals of the Rheumatic Diseases, vol. 54, no. 3, pp. 179-181, 1995.

[388] N. E. Lane, P. Lin, L. Christiansen et al., "Association of mild acetabular dysplasia with an increased risk of incident hip osteoarthritis in elderly white women. The study of osteoporotic fractures," Arthritis \& Rheumatism, vol. 43, pp. 400-404, 2000.

[389] S. Jacobsen, "Adult hip dysplasia and osteoarthritis," Acta Orthopaedica, vol. 77, pp. 2-37, 2007.
[390] K. Inoue, P. Wicart, T. Kawasaki et al., "Prevalence of hip osteoarthritis and acetabular dysplasia in French and Japanese adults," Rheumatology, vol. 39, no. 7, pp. 745-748, 2000.

[391] E. M. C. Lau, F. Lin, D. Lam, A. Silman, and P. Croft, "Hip osteoarthritis and dysplasia in Chinese men," Annals of the Rheumatic Diseases, vol. 54, no. 12, pp. 965-969, 1995.

[392] F. T. Hoaglund, A. C. M. C. Yau, and W. L. Wong, "Osteoarthritis of the hip and other joints in Southern Chinese in Hong Kong: incidence and related factors," Journal of Bone and Joint Surgery, American, vol. 55, pp. 545557, 1973.

[393] C.-D. Han, J.-H. Yoo, W.-S. Lee, and W.-S. Choe, "Radiographic parameters of acetabulum for dysplasia in Korean adults," Yonsei Medical Journal, vol. 39, no. 5, pp. 404-408, 1998.

[394] M. Moussa and A. Alomran, "Acetabular dysplasia in adult hips of a Saudi population. A possible relation to coxarthrosis," Saudi Medical Journal, vol. 28, no. 7, pp. 1059-1061, 2007.

[395] B. Goker, A. Sancak, and S. Haznedaroglu, "Radiographic hip osteoarthritis and acetabular dysplasia in Turkish men and women," Rheumatology International, vol. 25, no. 6, pp. 419422, 2005.

[396] S. Aktas, G. Pekindil, S. Ercan, and Y. Pekindil, "Acetabular dysplasia in normal Turkish adults," Bulletin Hospital for Joint Diseases, vol. 59, no. 3, pp. 158-162, 2000.

[397] M. Umer, A. Thambyah, W. T. Tan, and S. Das De, "Acetabular morphometry for determining hip dysplasia in the Singaporean population," Journal of Orthopaedic Surgery, vol. 14, no. 1, pp. 27-31, 2006.

[398] G. Wiberg, "Studies on dysplastic acetabula and congenital subluxation of the hip joint: with special reference to the complication of osteoarthritis," Acta Orthopaedica Scandinavica, vol. 83, supplement 58, pp. 1-135, 1939.

[399] A. F. Olshan, K. Teschke, and P. A. Baird, "Paternal occupation and congenital anomalies in offspring," American Journal of Industrial Medicine, vol. 20, no. 4, pp. 447-475, 1991.

[400] R. Wynne-Davies, A. Littlejohn, and J. Gormley, "Aetiology and interrelationship of some common skeletal deformities," Journal of Medical Genetics, vol. 19, no. 5, pp. 321-328, 1982.

[401] P. A. Baird, A. D. Sadovnick, and I. M. L. Yee, "Maternal age and birth defects: a population study," The Lancet, vol. 337, no. 8740, pp. 527-530, 1991.

[402] I. Amitai, A. Yarom, R. Bloch, and H. Pogrund, "Congenital dislocation of the hip and short maternal stature," Archives of Disease in Childhood, vol. 57, no. 11, pp. 875-877, 1982.

[403] P. M. Dunn, R. E. Evans, and M. Corfield, "Congenital dislocation of the hip and short maternal stature," Archives of Disease in Childhood, vol. 57, no. 12, p. 961, 1982.

[404] F. Gardner, C. Dezateux, D. Elbourne, A. Gray, A. King, and A. Quinn, "The hip trial: pyschosocial consequences for mothers of using ultrasound to manage infants with developmental hip dysplasia," Archives of Disease in Childhood, vol. 90, pp. F17-F24, 2005.

[405] S. U. Kamath and G. C. Bennet, "Does developmental dysplasia of the hip cause a delay in walking?" Journal of Pediatric Orthopaedics, vol. 24, no. 3, p. 265, 2004.

[406] N. Fredensborg and B. E. Nilsson, "Menarcheal age in girls with congenital dislocation of the hip," Acta Paediatrica Scandinavica, vol. 66, no. 2, pp. 241-242, 1977.

[407] Z. Pizio, "Congenital dysplasia of the hip and decrease of skin temperature at the periphery of the affected limb," Chirurgie 
Narzadow Ruchu i Ortopedia Polska, vol. 33, pp. 405-408, 1967.

[408] J. Blondiaux and F. Millot, "Dislocation of the hip: discussion of eleven cases from Mediaeval France," International Journal of Osteoarchaeology, vol. 1, pp. 203-207, 1991.

[409] B. Mafart, R. Kéfi, and E. Béraud-Colomb, "Palaeopathological and palaeogenetic study of 13 cases of developmental dysplasia of the hip with dislocation in a historical population from Southern France," International Journal of Osteoarchaeology, vol. 17, no. 1, pp. 26-38, 2007.

[410] P. D. Mitchell and R. C. Redfern, "The prevalence of dislocation in developmental dysplasia of the hip in Britain over the past thousand years," Journal of Pediatric Orthopaedics, vol. 27, no. 8, pp. 890-892, 2007.

[411] S. C. Hawkes and C. Wells, "The inhumed skeletal material from an early Anglo-Saxon cemetery in Worthy Park, Kingsworthy, Hampshire, South England," Paleobios, vol. 1, pp. 3-36, 1983.

[412] J. T. Eng, P. Szőcs, and C. Hagen, "Developmental dysplasia of the hip in a post-medieval Transylvanian population: case study and diagnosis," Paleopathol News, vol. 148, pp. 25-32, 2009.

[413] S. Masnicová and R. Beňuš, "Developmental anomalies in skeletal remains from the great Moravia and middle ages cemeteries at Devín (Slovakia)," International Journal of Osteoarchaeology, vol. 13, pp. 266-274, 2003.

[414] G. J. R. Maat, R. W. Mastwijk, and E. A. van der Velde, "Skeletal distribution of degenerative changes in vertebral osteophytosis, vertebral osteoarthritis and DISH," International Journal of Osteoarchaeology, vol. 5, pp. 289-298, 1995.

[415] A. R. Lieverse, . Bioarchaeology of the Cis-Baikal: biological indicators of mid-Holocene hunter-gatherer adaptation and cultural change, Ph.D. thesis, Cornell University, Ithaca, NY, USA, 2005.

[416] C. Bourbou, "Health patterns of proto-byzantine populations (6th-7th centuries AD) in South Greece: the cases of Eleutherna (Crete) and Messene (Peloponnese)," International Journal of Osteoarchaeology, vol. 13, no. 5, pp. 303-313, 2003.

[417] A. R. Lieverse, Palaeopathology in the osteological collection of anthropological museum in Padova university: the cases of tuberculosis, Ph.D. thesis, University of Padua, Padua, Italy, 2008.

[418] C. Bisel, "The human skeletons of herculaneum," International Journal of Anthropology, vol. 6, no. 1, pp. 1-20, 1991.

[419] M. S. Goldstein, B. Arensburg, and H. Nathan, "Pathology of Bedouin skeletal remains from two sites in Israel," American Journal of Physical Anthropology, vol. 45, no. 3, pp. 621-639, 1976.

[420] D. J. Ortner, "Disease and mortality in the Early Bronze Age people of Bab edh-Dhra, Jordan," American Journal of Physical Anthropology, vol. 51, no. 4, pp. 589-597, 1979.

[421] I. Mathieson, E. Bettles, J. Clarke et al., "The National Museums of Scotland Saqqara Survey Project, 1993-1995," Journal of Egyptian Archaeology, vol. 83, pp. 17-53, 1997.

[422] M. M. Lahr and J. E. Bowan, "Paleopathology of the Kechipawan site: health and disease in a south-western pueblo," Journal of Archaeological Science, vol. 19, pp. 639654, 1992.

[423] S. Pfeiffer, "Paleopathology in an Iroquoian ossuary, with special reference to tuberculosis," American Journal of Physical Anthropology, vol. 65, no. 2, pp. 181-189, 1984.
[424] M. S. Clabeaux, "Congenital dislocation of the hip in the prehistoric northeast," Bulletin of the New York Academy of Medicine, vol. 53, no. 4, pp. 338-346, 1977.

[425] E. G. Wakefield, S. C. Dellinger, and J. D. Camp, "A study of the osseous remains of the "mound builders" of eastern Arkansas," American Journal of the Medical Sciences, vol. 193, pp. 488-495, 1937.

[426] J. B. Gregg, L. J. Zimmerman, J. P. Steele, H. Ferwerda, and P. S. Gregg, "Ante-mortem osteopathology at Crow Creek," Plains Anthropologist, vol. 26, no. 94, pp. 287-300, 1981.

[427] J. S. Miles, Orthopedic Problems of the Wetherill Mesa Populations, US Department of the Interior National Park Service, Washington, DC, USA, 1975.

[428] M. S. Goldstein, "Skeletal pathology of early Indians in Texas," American Journal of Physical Anthropology, vol. 15, no. 3, pp. 299-310, 1957.

[429] C. J. Loveland, J. B. Gregg, and W. M. Bass, "Ancient osteopathology from the Caddoan burials at the KaufmanWilliams site, Texas," Plains Anthropologist, vol. 30, no. 107, pp. 29-43, 1985.

[430] R. L. Wheeler, "Pathology in late thirteenth century Zuni from the El Morro Valley, New Mexico," in Health and Disease in the Prehistoric Southwest, C. F. Merbs and R. J. Miller, Eds., vol. 34, pp. 79-84, Arizona State University Anthropological Research Paper, Tempe, Ariz, USA, 1985.

[431] C. F. Merbs and E. M. Vestergaard, "The paleopathology of Sundown, a prehistoric site near Prescott, Arizona," in Health and Disease in the Prehistoric Southwest, C. F. Merbs and R. J. Miller, Eds., vol. 34, pp. 115-127, Arizona State University Anthropological Research Paper, Tempe, Ariz, USA, 1985.

[432] A. Drusini, F. Businaro, and F. L. Calderon, "Skeletal biology of the Taino: a preliminary report," International Journal of Anthropology, vol. 2, no. 3, pp. 247-254, 1987.

[433] C. D. Hummer Jr. and G. D. MacEwen, "The coexistence of torticollis and congenital dysplasia of the hip," Journal of Bone and Joint Surgery, American, vol. 54, no. 6, pp. 1255-1256, 1972.

[434] J. Von Heideken, D. W. Green, S. W. Burke et al., "The relationship between developmental dysplasia of the hip and congenital muscular torticollis," Journal of Pediatric Orthopaedics, vol. 26, no. 6, pp. 805-808, 2006.

[435] J. J. Walsh and R. T. Morrissy, "Torticollis and hip dislocation," Journal of Pediatric Orthopaedics, vol. 18, no. 2, pp. 219-221, 1998.

[436] J. C. Y. Cheng, S. P. Tang, and T. M. K. Chen, "Sternocleidomastoid pseudotumor and congenital muscular torticollis in infants: a prospective study of 510 cases," Journal of Pediatrics, vol. 134, no. 6, pp. 712-716, 1999.

[437] J. C. Y. Cheng, S. P. Tang, T. M. K. Chen, M. W. N. Wong, and E. M. C. Wong, "The clinical presentation and outcome of treatment of congenital muscular torticollis in infants-a study of 1,086 cases," Journal of Pediatric Surgery, vol. 35, no. 7, pp. 1091-1096, 2000.

[438] D. S. Weiner, "Congenital dislocation of the hip associated with congenital muscular torticollis," Clinical Orthopaedics and Related Research, vol. 121, pp. 163-165, 1976.

[439] D. L. Morrison and G. D. MacEwen, "Congenital muscular torticollis: observations regarding clinical findings, associated conditions, and results of treatment," Journal of Pediatric Orthopaedics, vol. 2, no. 5, pp. 500-505, 1982.

[440] K. P. Minihane, J. J. Grayhack, T. D. Simmons, R. Seshadri, R. W. Wysocki, and J. F. Sarwark, "Developmental dysplasia 
of the hip in infants with congenital muscular torticollis," American Journal of Orthopedics, vol. 37, no. 9, pp. E155E158, 2008.

[441] J. C. Y. Cheng and A. W. Y. Au, "Infantile torticollis: a review of 624 cases," Journal of Pediatric Orthopaedics, vol. 14, no. 6, pp. 802-808, 1994.

[442] T. Iwahara and A. Ikeda, "On the ipsilateral involvement of congenital muscular torticollis and congenital dislocation of the hip," Journal of Japanese Orthopaedic Association, vol. 35, pp. 1221-1226, 1962.

[443] Y. C. Tien, J. Y. Su, G. T. Lin, and S. Y. Lin, "Ultrasonographic study of the coexistence of muscular torticollis and dysplasia of the hip," Journal of Pediatric Orthopaedics, vol. 21, no. 3, pp. 343-347, 2001.

[444] S. J. Kumar and G. D. MacEwen, "The incidence of hip dysplasia with metatarsus adductus," Clinical Orthopaedics and Related Research, vol. 164, pp. 234-235, 1982.

[445] J. E. Jacobs, "Metatarsus varus and hip dysplasia," Clinical Orthopaedics, vol. 16, pp. 203-213, 1960.

[446] J. H. Kite, "Congenital anomalies associated with clubfeet," Journal of the Medical Association of Georgia, vol. 52, pp. 429431, 1963.

[447] D. E. Westberry, J. R. Davids, and L. I. Pugh, "Clubfoot and developmental dysplasia of the hip: value of screening hip radiographis in children with clubfoot," Journal of Pediatric Orthopaedics, vol. 23, pp. 503-507, 2003.

[448] D. C. Perry, S. M. Tawfiq, A. Roche et al., "The association between clubfoot and developmental dysplasia of the hip," Journal of Bone and Joint Surgery, British, vol. 92, no. 11, pp. 1586-1588, 2010.

[449] B. T. Carney and E. A. Vanek, "Incidence of hip dysplasia in idiopathic clubfoot," Journal of Surgical Orthopaedic Advances, vol. 15, no. 2, pp. 71-73, 2006.

[450] R. W. Paton and Q. Choudry, "Neonatal foot deformities and their relationship to developmental dysplasia of the hip: an 11-year prospective, longitudinal observational study," Journal of Bone and Joint Surgery, British, vol. 91, no. 5, pp. 655-658, 2009.

[451] J. A. Wilkinson and E. M. Sedgwick, "Occult spinal dysraphism in established congenital dislocation of the hip," Journal of Bone and Joint Surgery, British, vol. 70, no. 5, pp. 744-749, 1988.

[452] G. Hooper, "Congenital dislocation of the hip in infantile idiopathic scoliosis," Journal of Bone and Joint Surgery, British, vol. 62, no. 4, pp. 447-449, 1980.

[453] H. H. Muratli, A. Bicimoğlu, Y. A. Tabak, L. Çelebi, and İ. Pakel, "Mechanoreceptor evaluation of hip joint capsule and ligamentum capitis femoris in developmental hip dysplasia: a preliminary study," Journal of Pediatric Orthopaedics B, vol. 13, pp. 293-302, 2004.

[454] M. Leunig, M. Beck, E. Stauffer, R. Hertel, and R. Ganz, "Free nerve endings in the ligamentum capitis femoris," Acta Orthopaedica Scandinavica, vol. 71, pp. 452-454, 2000.

[455] W. G. Kernohan, G. H. Cowie, and R. A. B. Mollan, "Vibration arthrometry in congenital dislocation of the hip," Clinical Orthopaedics and Related Research, no. 272, pp. 167174, 1991.

[456] W. G. Kernohan, B. Trainor, G. Nugent, P. Walker, M. Timoney, and R. Mollan, "Low-frequency vibration emitted from unstable hip in human neonate," Clinical Orthopaedics and Related Research, vol. 288, pp. 214-218, 1993.

[457] J. Matsoukas, D. Papadimitriou, and C. Euthymiou, "Histologic study of the pelvic and femoral muscles in infants suffering from congenital hip dislocation. Original histopatho- logic findings," Helvetica Paediatrica Acta, vol. 24, no. 2, pp. 201-207, 1969.

[458] W. Dunaj, "Influence of a myogenic factor on formation of congenitla dislocation of the hip," Chirurgie Narzadow Ruchu i Ortopedia Polska, vol. 35, pp. 331-338, 1970.

[459] D. Tönnis, "Electromyographic and histologic study of the pathogenesis of congenital dislocation of the hip," Zeitschrift Fur Orthopadie Und Ihre Grenzgebiete, vol. 105, pp. 527-552, 1969.

[460] D. Kobayashi, S. Satsuma, R. Kuroda, and M. Kurosaka, "Acetabular development in the contralateral hip in patients with unilateral developmental dysplasia of the hip," Journal of Bone and Joint Surgery, American, vol. 92, no. 6, pp. 13901397, 2010.

[461] B. G. Bolton-Maggs and S. D. Crabtree, "The opposite hip in congenital dislocation of the hip," Journal of Bone and Joint Surgery, British, vol. 65, no. 3, pp. 279-284, 1983.

[462] S. Jacobsen, L. Rømer, and K. Søballe, "The other hip in unilateral hip dysplasia," Clinical Orthopaedics and Related Research, no. 446, pp. 239-246, 2006.

[463] N. E. Green and P. P. Griffin, "Hip dysplasia associated with abduction contracture of the contralateral hip," Journal of Bone and Joint Surgery, American, vol. 64, no. 9, pp. 12731281, 1982.

[464] I. Komprda, "Influence of oblique position on postnatal development of hip joints," Acta Chirurgiae Orthopaedicae et Traumatologiae Cechoslovaca, vol. 44, pp. 511-523, 1977.

[465] J. Albiñana, J. A. Morcuende, E. Delgado, and S. L. Weinstein, "Radiologic pelvic asymmetry in unilateral late-diagnosed developmental dysplasia of the hip," Journal of Pediatric Orthopaedics, vol. 15, no. 6, pp. 753-762, 1995.

[466] D. R. Cooperman, R. Wallensten, and S. D. Stulberg, "Acetabular dysplasia in the adult," Clinical Orthopaedics and Related Research, vol. 175, pp. 79-85, 1983.

[467] I. Ø. Engesæter, S. A. Lie, T. G. Lehmann, O. Furnes, S. E. Vollset, and L. B. Engesæter, "Neonatal hip instability and risk of total hip replacement in young adulthood: followup of 2,218,596 newborns from the Medical Birth Registry of Norway in the Norwegian Arthroplasty Register," Acta Orthopaedica, vol. 79, no. 3, pp. 321-326, 2008.

[468] G. Mangat and P. Dieppe, "Hypermobility, arthritis and congenital hip dislocation," British Journal of Rheumatology, vol. 29, no. 1, p. 77, 1990.

[469] H. A. Bird, C. R. Tribe, and P. A. Bacon, "Joint hypermobility leading to osteoarthritis and chondrocalcinosis," Annals of the Rheumatic Diseases, vol. 37, pp. 203-211, 1978.

[470] D. S. Garbuz, B. A. Masri, F. Haddad, and C. P. Duncan, "Clinical and radiographic assessment of the young adult with symptomatic hip dysplasia," Clinical Orthopaedics and Related Research, no. 418, pp. 18-22, 2004.

[471] A. Troelsen, L. Rømer, S. Kring, B. Elmengaard, and K. Søballe, "Assessment of hip dysplasia and osteoarthritis: variability of different methods," Acta Radiologica, vol. 51, no. 2, pp. 187-193, 2010.

[472] E. M. C. Lau, D. P. M. Symmons, and P. Croft, "The epidemiology of hip osteoarthritis and rheumatoid arthritis in the orient," Clinical Orthopaedics and Related Research, no. 323, pp. 81-90, 1996.

[473] F. T. Hoaglund, C. S. Oishi, and G. G. Gialamas, "Extreme variations in racial rates of total hip arthroplasty for primary coxarthrosis: a population-based study in San Francisco," Annals of the Rheumatic Diseases, vol. 54, pp. 107-110, 1995.

[474] F. T. Hoaglund, R. Shiba, A. H. Newberg, and K. Y. K. Leung, "Diseases of the hip. A comparative study of Japanese 
Oriental and American white patients," Journal of Bone and Joint Surgery, American, vol. 67, no. 9, pp. 1376-1383, 1985.

[475] F. T. Hoaglund and L. S. Steinbach, "Primary osteoarthritis of the hip: etiology and epidemiology," The Journal of the American Academy of Orthopaedic Surgeons, vol. 9, no. 5, pp. 320-327, 2001.

[476] K. Johnsen, R. Goll, and O. Reikerås, "Acetabular dysplasia as an aetiological factor in development of hip osteoarthritis," International Orthopaedics, vol. 33, no. 3, pp. 653-657, 2009.

[477] K. Okano, M. Takaki, N. Okazaki, and H. Shindo, "Bilateral incidence and severity of acetabular dysplasia of the hip," Journal of Orthopaedic Science, vol. 13, no. 5, pp. 401-404, 2008.

[478] Y. Hasegawa, H. Iwata, M. Mizuno, E. Genda, S. Sato, and T. Miura, "The natural course of osteoarthritis of the hip due to subluxation or acetabular dysplasia," Archives of Orthopaedic and Trauma Surgery, vol. 111, no. 4, pp. 187-191, 1992.

[479] S. Nakamura, S. Ninomiya, and T. Nakamura, "Primary osteoarthritis of the hip joint in Japan," Clinical Orthopaedics and Related Research, no. 241, pp. 190-196, 1989.

[480] I. Rouse, The Tainos: Rise and Decline of the People who Greeted Columbus, Yale University Press, New Haven, Conn, USA, 1992. 


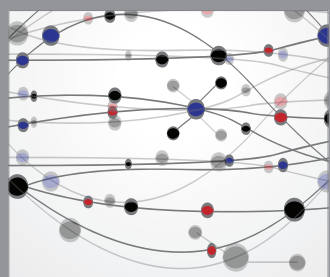

The Scientific World Journal
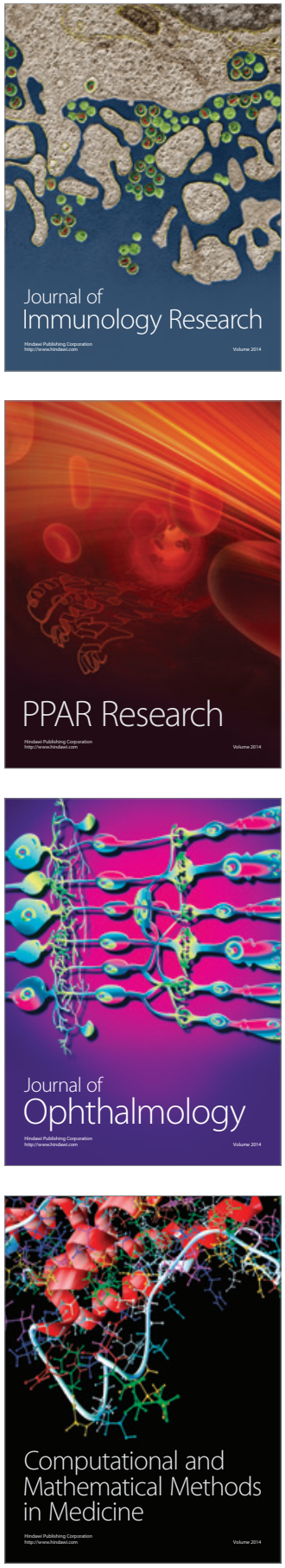

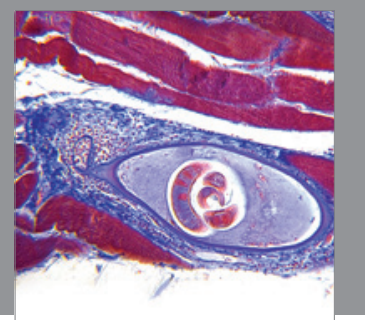

Gastroenterology

Research and Practice
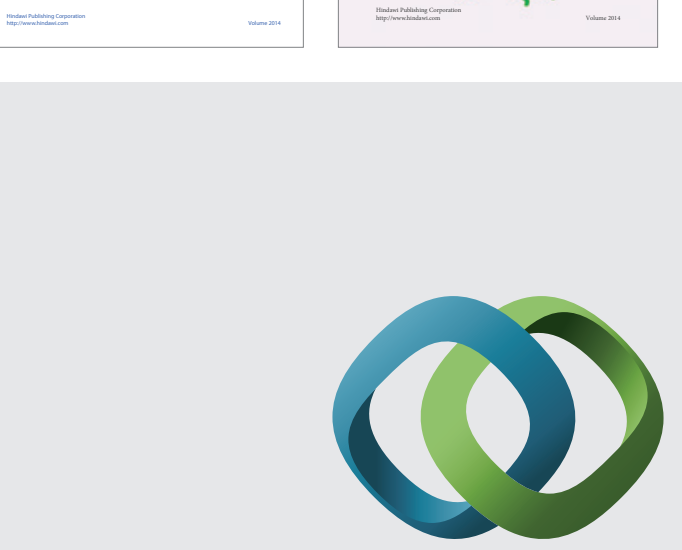

\section{Hindawi}

Submit your manuscripts at

http://www.hindawi.com
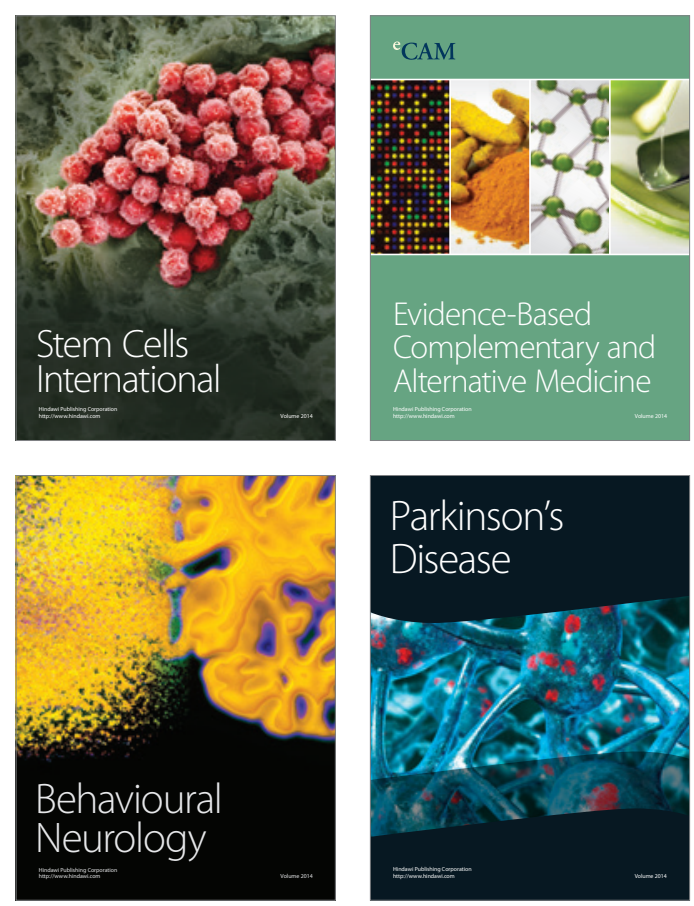

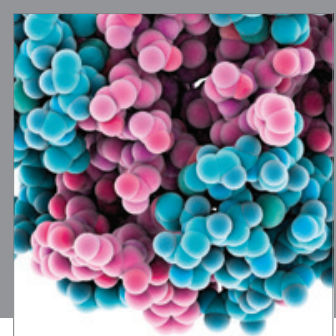

Journal of
Diabetes Research

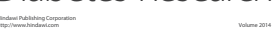

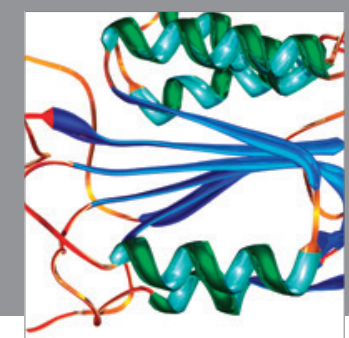

Disease Markers
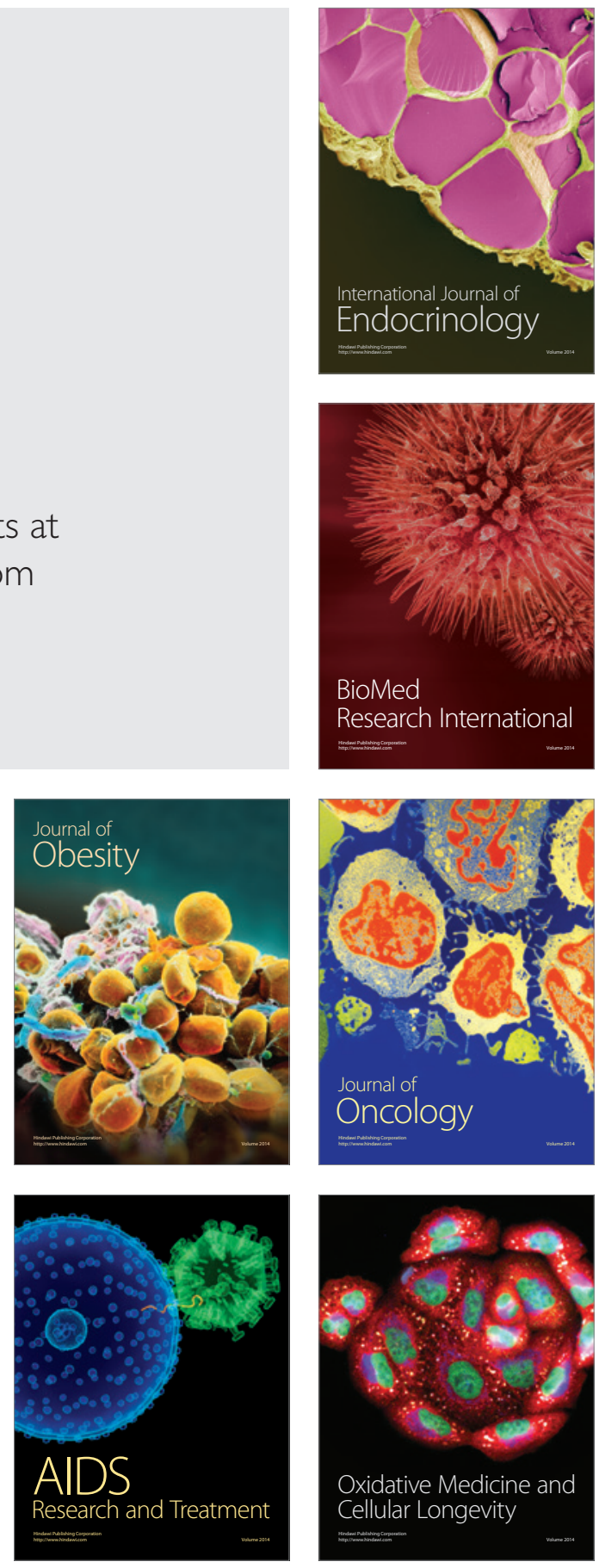